Pontifícia Universidade Católica $_{\text {a }}$

Gravi.

Leandro Innocenzi Alves de Souza

"Resíduo zero": estudo da proposta socioambiental de redução da geração de lixo na cidade do Rio de Janeiro

Dissertação de Mestrado

Dissertação apresentada ao Programa de Pósgraduação em Engenharia Urbana e Ambiental da PUC-Rio como requisito parcial para obtenção do título de Mestre em Engenharia Urbana e Ambiental (Opção Profissional).

Orientadora: Prof. ${ }^{a}$ Valéria Pereira Bastos 
Pontifícia Universidade Católica $_{\text {a }}$

DO RIO DE JANEIRO

GRAVB.

Leandro Innocenzi Alves de Souza

"Resíduo zero": estudo da proposta socioambiental de redução da geração de lixo na cidade do Rio de Janeiro

Dissertação apresentada ao Programa de Pósgraduação em Engenharia Urbana e Ambiental da PUC-Rio como requisito parcial para obtenção do título de Mestre em Engenharia Urbana e Ambiental (Opção Profissional). Aprovada pela Comissão Examinadora abaixo assinada.

\section{Prof. ${ }^{a}$ Valéria Pereira Bastos}

Orientadora

Departamento de Serviço Social - PUC-Rio

Prof. Rafael Soares Gonçalves Departamento de Serviço Social - PUC-Rio

Prof. Ubirajara Aluízio de Oliveira Mattos Departamento de Engenharia Ambiental - UERJ

Prof. Jose Eugenio Leal Coordenador Setorial do Centro

Técnico Científico - PUC-Rio

Rio de Janeiro, 01 de Junho de 2015 
Todos os direitos reservados. É proibida a reprodução total ou parcial do trabalho sem autorização da universidade, do autor e da orientadora.

\section{Leandro Innocenzi Alves de Souza}

Graduou-se em Administração de Empresa pela Pontificia Universidade Católica do Rio de Janeiro em 2007. Especializou-se em Gestão de Serviços no ano de 2009 pela Escola Superior de Propaganda e Marketing de São Paulo. Trabalha na área de gerenciamento de produtos em projetos de lançamento de novos serviços e desenvolvimento de negócio. Dentre as principais atividades desenvolvidas estão o gerenciamento do ciclo de vida do produto, gestão de contratos com operadoras parceiras e o desenvolvimento de análises comerciais.

Ficha Catalográfica

Souza, Leandro Innocenzi Alves de

"Resíduo zero": estudo da proposta socioambiental de redução da geração de lixo na cidade do Rio de Janeiro / Leandro Innocenzi Alves de Souza ; orientadora: Valéria Pereira Bastos. 2015.

107 f. : il. (color.) ; $30 \mathrm{~cm}$

Dissertação (mestrado profissional)Pontifícia Universidade Católica do Rio de Janeiro, Departamento de Engenharia Civil, Programa de Pós-Graduação em Engenharia Urbana e Ambiental, 2015.

\section{Inclui bibliografia}

1. Engenharia civil - Teses. 2. Engenharia Urbana e Ambiental - Teses. 3. Redução de resíduos. 4. Política pública. 5. Educação ambiental. I. Bastos, Valéria Pereira. II. Pontifícia Universidade Católica do Rio de Janeiro. Departamento de Engenharia Civil. III. Technische Universität Braunschweig. Fakultät Architektur, Bauingenieurwesen und Umweltwissenschaften. IV.Título. 


\section{Agradecimentos}

Agradeço aos meus pais José Carlos e Rosane, ao meu irmão André, minha tia Eliane, a Mariana, ao Zion e aos amigos e a todos que colaboraram direta e ญ indiretamente para a minha formação profissional.

A Professora orientadora Valéria Bastos, uma grande gratidão pelo apoio, conhecimento prestado e parceria.

Aos professores e à Pontificia Universidade Católica do Rio de Janeiro, por formarem um centro de formação renomado, me deram a oportunidade de obter o título de mestre no curso de Engenharia Ambiental e Urbana e foram muito importantes na construção da minha formação.

Agradeço profundamente os amigos e pessoas que conheci ao longo dessa jornada e que de diferentes maneiras contribuíram no meu processo de aprendizado. 


\section{Resumo}

Souza, Leandro Innocenzi Alves de Souza; Bastos, Valéria Pereira (Orientadora). Resíduo zero: estudo da proposta socioambiental de redução da geração de lixo na cidade do Rio de Janeiro. Rio de Janeiro, 2015. 107p. Dissertação de Mestrado (opção profissional) - Departamento de Engenharia Civil, Pontifícia Universidade Católica do Rio de Janeiro.

Esta dissertação busca propor alternativas que reduzam a produção dos resíduos sólidos urbanos na cidade do Rio de Janeiro à luz de uma visão de sustentabilidade ambiental. Para tanto, utilizamos como categorias de análises os conceitos de consumo, de educação ambiental crítica, da política pública voltada para área de resíduos sólidos e de resiliência, na busca de encontrarmos a melhor forma da aplicabilidade dos conceitos eleitos na construção da proposta de mitigação da excessiva produção de lixo pela população carioca. O estudo proposto partiu do que preceitua a recente Lei 12.305/2010, Política Nacional de Resíduos Sólidos, que determina em seus artigos a importância da gestão dos resíduos sólidos urbanos; seu tratamento e destinação final, bem como sua redução no processo de geração. Para tanto, efetuamos um estudo comparativo, tomando como referência o Plano de gestão de resíduos sólidos de Nova Iorque, cidade considerada capital do consumo, e o Plano da cidade do Rio de Janeiro. E ao final, sugerimos a implantação de estratégias sustentáveis para implementação na cidade de novos procedimentos para atuação junto à população, no sentido de sensibilizá-la para através de um processo socioeducativo não só reduzir a produção de lixo, bem como de descartá-lo de forma adequada.

\section{Palavras-chave}

Política Nacional de Resíduos Sólidos; Educação Ambiental; Resíduos Sólidos Urbanos; Redução de Resíduos. 


\section{Extended abstract}

Souza, Leandro Innocenzi Alves de Souza; Bastos, Valéria Pereira (advisor). "Zero waste": study of environmental proposal to reduce the generation of waste in the city of Rio de Janeiro. Rio de Janeiro. 2015. 107p. MSc. Dissertation - Departamento de Engenharia Civil, Pontifícia Universidade Católica do Rio de Janeiro.

The current model of Brazilian economic development associated with population growth and the new consumption trends, in recent decades, give to contemporary society the title of Throwaway Economy, according to Brown (2003), so, being the main contribution to the extreme generation of Urban Solid Waste (or Municipal Solid Waste - MSW) . The list of products consumed and discarded every day is extensive and, therefore, natural resources become increasingly scarce. The raw material is extracted from nature, processed, manufactured and then sold as consumer goods to meet the needs and desires of thousands of consumers in Brazil.

Today, the excessive generation of waste is one of biggest environmental challenges on the agenda of municipalities, so demanding a need to apply technology and changes in the disposal behavior of the society as a whole. The management of MSW usually is a great difficulty for municipalities responsible for it, since the areas close to urban centers, designed to house such wastes, are becoming increasingly rare, complex and challenged to find. Also, the intense traffic of garbage trucks, noise and unpleasant odor is the main problem related by people who reject to live or working near a Landfill or Waste Treatment Center; such feature was corroborated by the findings of both metropolitan areas surveyed.

Therefore, the management of MSW becomes crucial for the sustainable development of cities. Improper handling of waste and its disposal at noncontrolled locations can cause serious environmental damages, what may take 
years to be repaired, also, social problems, since it promotes waste picking activity $^{1}$ without any zeal for human health.

The Brazilian government in face of this intricate challenge - that involves different segments of society -, considering it is not only an environmental issue, but also economic and social, have launched in August, 2010 the Brazilian National Solid Waste Policy - (Política Nacional de Resíduos Sólidos - PNRS), a necessary and important legal measure, since conflicts of interest arise, so requiring solutions. The Brazilian National Plan gathers business companies, civil society and the public management, which is extremely important for the responsible management of waste generated in each of the municipalities (BRAZIL, 2010). The Plan have determined until August 2, 2014 to the extinction of lixões ${ }^{2}$ in all Brazilian municipalities. However, days after its publication, ABRELPE reports were released highlighting the challenging numbers for Municipalities: according to them, there were approximately 3,500 active landfills in all regions of Brazil. Also, this was not the first attempt failed to achieve the goal of eradication of lixões.

So, this work is a theoretical efforts aiming at identify possible measures to non-generating municipal waste / waste prevention, not only to meet what determines the Plan, but as a sustainable alternative for municipal waste management in the city of Rio de Janeiro. For that, a comparative study between two cities - Rio de Janeiro, RJ and New York, NYC, was carried out, by means the analysis of municipal Land-use planning to raise best practices and socioeducational alternatives seeking to reduce wastes at Rio de Janeiro.

In this sense, the goal is to stop concerning about solutions to waste management and the consequences of pollution, to focus on non-generation / reduction of waste, what is considered essential for an efficient waste management. Therefore, by means the environmental education, we intend to propose some measures seeking the conscious consuming, avoiding waste, reusing and recycling of materials as alternatives to reduce the economic and

\footnotetext{
${ }^{1}$ Waste picking is a scavenger activity developed as a source of livelihood to extremely poor people with few other employment opportunities.

${ }^{2}$ Open dumps.
} 
environmental costs by a smarter and efficient use of energy and natural resources.

The city of Rio de Janeiro was chosen because its "conservative" waste management, with very low levels of recycling compared to its increasing levels of waste generation per person, even after launched the Brazilian National Plan 12.305/2010. .Based on bibliographic research, the study was carried out from January to April of 2015. Along the official documentation - produced by the company responsible for waste management in the RJ -, we have followed the news about waste management at Rio de Janeiro, making a news clipping.

New York City was chosen considering its high population density, its huge quantities of waste produced daily, and the way the city manages these wastes: "exporting" to near cities. In addition to bibliographic research, a contact was made with specialists. The literature review was based on analysis of municipal land-use planning (from NYC and the "waste receivers" cities) aiming to suggest sustainable alternatives for non generation of waste (mentioned in the Brazilian National Plan 12.305/2010). It is noteworthy that NYC has a recyclable materials rate by $15 \%$ and for household waste the recycling rate reached $27 \%$ according the PlaNYC 2011.

Observing the Municipal Solid Waste Management Planning of Rio de Janeiro and the actions of the public administration, it is easy to conclude that waste management is also addressed in a conservative manner, emphasizing the disposal, clearly in disagreement with the Brazilian National Plan - that, according to aforementioned, emphasizes the reduction of waste generation. The percentage of recycled materials in Rio de Janeiro is still low despite the city waste sorting covers considerably the city districts.

The Municipal Solid Waste Management Planning of Rio de Janeiro is based just on the content core $e^{3}$ of Brazilian National Plan (strongly focused on non-generation and reduction of waste), but the document still has many points treated superficially, with no proper focus attention on strategies to deal with the current problems, so anticipating the future challenges. Despite having the same

\footnotetext{
${ }^{3}$ The MSW management planning of RJ, dos not emphasize the non-generation and reduction of waste, but the waste sorting.
} 
objectives as Brazilian National Plan, the MSW Planning of Rio de Janeiro does not clarify what measures will (or should) be taken to achieve the intended results. Also, an important point that must be highlighted is the apathy of public representatives; since the MSW Planning is updated only every four years, so presenting discontinued activities and projects that were supposed to be released in accordance with the Municipal Plan; and, even those measures that were implemented, have not its actions published (what is expected to inform the public). These failures are the main reason why the Federal government has not yet recognized the MSW Planning Rio de Janeiro. In comparison, the MSW Planning of NYC is updated annually, so its actions and goals are better monitoring (followed) avoiding being outdated.

The term "Zero Waste" means differently in Rio de Janeiro (since the worldwide meaning is the redesign of resource life cycles, reusing all products, with no trash sent to landfills and incinerators). In Rio de Janeiro, besides the educative purpose, the "Zero Waste" has a punitive nature, not aiming the citizens education about the problem of MSW; it seems to be limited to disposal of waste on recycle bins. Even though it avoids pollution and contributes to the improvement of public health, this action could be more effective if take into account the key concepts of Environmental Education National Plan, addressing the issue in a comprehensive way, exposing the real problems of generation and improper disposal of waste. According to Comlurb ${ }^{4}$ reports (2015), there is the mobilization of over 600 professionals for the supervision, and partnerships with the city's urban mobility companies to publicize the campaign. However, the most important point in the Brazilian National Plan - the non-generation and reduction of waste -, does not receives any incentive from this public action.

According to data from the Brazilian National Sanitation Information System (Sistema Nacional de Informações sobre Saneamento - SNIS), in 2013, an amount of R $\$ 217.00$ per ton were spent by the city of Rio de Janeiro with street sweeping, and R $\$ 150.00$ per ton with waste collection, i.e., sweeping costs $44.5 \%$ more than the collection; So, it is not incorrect to identify and point out that the improper disposal burdens the budget. Economic coercive measures such as fines,

\footnotetext{
${ }^{4}$ Company responsible for the urban cleaning services in Rio de Janeiro.
} 
may show good results if there is supervision and, in this case, the installation and maintenance of public trash cans. However, it is important to highlight that an educational approach focusing on waste prevention, would enable lower costs with street sweeping and waste collection since there would be less waste to be transported and dumped. Today, there is a global trend to reduce and prevent waste generation, so reducing the costs with waste management.

Recycling and composting are alternatives with environmental benefits, since they favor waste reduction, plus contributing to economic and social matters. A suitable organic compost to nourish the soil for agriculture, correct any soil acidity and reforestation are important contributions of composting plants (MONTEIRO, 2001).

According to the gravimetric characterization of Rio de Janeiro, the amount of organic matter exceeds the total of potential recycling materials. Therefore, it is important to consider solutions for the reuse of organic matter, since it can be reused as fertilizer and contribute to the reduction of greenhouse gases. As highlighted in the MSW Planning of Rio de Janeiro, Comlurb already produces the organic compound, at Usina do Caju (Caju Plant), approximately 15 thousand cubic meters per year. However, this number could be higher if new technologies was applied and the compound use was expanded, so its production could be economically viable.

Also, the percentage of recycled materials is not higher because of delays on construction of new recycling plants in the city. Despite the agreement with Brazilian Development Bank (BNDES) was signed in late 2010, just Waste Treatment Center of Irajá was inaugurated - with a delay of 18 months.

(Actions seeking to environmental education for waste sorting, covered by the MSW Planning of Rio de Janeiro, was not found during the elaboration of this study.) The public waste sorting officially starts in the South side of Rio de Janeiro, in February 2002, as a pilot experiment aiming to meet the requirements of the Municipal Plan of Urban Sanitation No.3273 of September, 2001. Today, Comlurb (January 2015) reports a gradual increase of locations covered by the waste sorting collection: in January 2015, 67 of the 160 districts. According to the Brazilian National Sanitation Information System, the waste sorting coverage rate, 
compared to the urban population, increases $76.01 \%$ between the years of 2012 and 2013 - there is no information about years prior to 2012.

Although more than half of the population is served by waste sorting in the city of Rio de Janeiro, the amount of material recycled is still extremely low - less than 1\%, compared to the amount of household waste and public waste in 2013.

Monteiro (2001), points out that according to experts, the recycled industry will only succeed if there is a strong investment of municipalities (government), following the European example. To Bastos (2014) the situation of cooperatives in Rio de Janeiro requires attention, because, despite the Comlurb projects for new recycling units, and the gradual increase of public waste sorting collection, these initiatives are not reversed in profit for cooperatives, once, before arriving at recycling plants, potential materials for recycling are collected by waste pickers and/or intermediaries, so reaching the units only part of the household waste. According to Bastos (2014) this was the key reason for the deactivation of Botafogo Plant in 2006.

It leads to conclude that, the three levels of government must encourage with investments - the recycling process. Also, educational campaigns showing the benefits of recycling and how to recycle/sort, as well as supervision to inhibit the action of intermediaries are some actions needed to leverage the recycling process at Rio de Janeiro. In addition, it is necessary to reduce taxes on recycled products and materials to motivate industries to invest on these products. Today, there is no differentiation between the taxation of first manufacture product and after recycled, for example, IPI (Tax on Industrialized Products), or ICMS (Tax on Goods and Services), so the product is taxed more than once: when first manufactured and when recycled.

Alternatively, dumpsters - installed on public streets - could boost the waste collection, since it could expand the discharge points and the volunteers delivery of waste sorted. In Rio de Janeiro there is no waste sorting for urban waste, however this type of waste is $34 \%$ (SNIS, 2013), i.e., a significant portion of the total collected in the municipality. The economic feasibility of dumpsters on public spaces could be achieved by partnerships with private companies; these companies could finance the dumpsters placement, after using its space for 
marketing/advertising. In NYC, dumpsters were strategically installed on public spaces to boost the rate of recycled materials, considering that recycling capacity have increased after the inauguration of southern Brooklyn Unit, able to optically sort plastic, metal and glass.

According to the "Inventory and scenario of greenhouse gas emissions of the City of Rio de Janeiro: Summary technical" published by Coleção Estudos Cariocas (RIO DE JANEIRO, 2011) ${ }^{5}$, burning of fuels - road transportation and cars - are responsible for $33 \%$ of pollutant gases emissions in the city, followed by gases emissions from waste, $25 \%$. Therefore, it is easy to conclude that MSW management and road transportation are fundamental to achieve the goal proposed by the city public administration of reducing gases emissions between the years 2016 and 2020.

Another similarity between NYC and RJ, was the recent shutdown of controlled landfills. In NYC, Fresh Kill, was closed in 2001 and in RJ, Jardim de Gramacho municipal landfill in 2012. Globally recognized for receiving approximately 39 thousand tons per day, respectively, their operations and shutdowns were a milestone for both cities. Waste disposal costs were the big draw for the two municipalities, despite the strong pressure from environmentalists and society for its closure because of the environmental and social damage in their respective regions. In March, 2015 a Parliamentary Commission of Inquiry was opened, and must investigate that, despite the amount charged by ton of waste disposed in the Seropédica landfill is, at least, eight times higher than in Gramacho, the Comlurb reports expenses - presented by the SNIS (2013) - with no significant difference from expenses in 2012, year of the shutdown of Gramacho.

According the PlaNYC, the public administration sponsors events to collect donations and dispose hazard waste, which requires a proper handling. This is a simple action that could be implemented in Rio de Janeiro with low costs. Moreover, it could be an important tool for an adequate disposal high-value materials, such as lead $(\mathrm{Pb})$ and copper $(\mathrm{Cu})$. In addition to the environmental

\footnotetext{
${ }^{5}$ Inventário e cenário de emissões de gases do efeito estufa da Cidade do Rio de Janeiro: resumo técnico - original title in Portuguese.
} 
benefits, the donation of objects would be a social improvement for poorest people, once they could purchase products that would otherwise be discarded.

According to Garmerman, Brecher and Dardia (2015) points out that solid waste management of NYC needs a review, despite the several initiatives. If compared to the costs of the private sector, the city spend twice this amount, plus taxation and environmental costs. In 2012, New York spent \$1.5 billion with MSW. Also, New Yorkers are unaware of the increasing costs of MSW currently, a fixed amount is paid, per house, as in Rio de Janeiro -, so the authors suggest an extra taxation for volume of waste produced. Garmerman, Brecher and Dardia also have shown that in other American cities, where this model has been implemented, the waste diversion rate is higher than the NYC. It is due to people became aware of the costs of MSW, once they pay a variable amount in accordance with the generated volume. They also highlight that, jointly to this new taxation, educational activities toward waste prevention must be implemented.

From this analysis, it was concluded that there is a long way to go to reduce the MSW in the city of Rio de Janeiro. The Brazilian National Plan is an important tool to bring society together and make every people responsible for their waste. Moreover, the Plan is based on the pillars, i.e., actions that focus on non-generation, reduction, reuse, recycling and composting of the material, in order to reduce waste generated daily by the population, and after sent to landfills. Despite the modern Throwaway Society, there is a new movement, not yet established in Rio de Janeiro, that emphasizes the "Waste Zero", i.e., waste prevention / non-generation.

The involvement of the public administration by tax incentive, transparency in the public accounts, actions of environmental education with focus on the harmful effects of waste generation, and holding events for donation and restoration of products into disuse, are essential. Despite the city's goal to reduce GHG emissions already in 2016, there are few actions aimed at this goal, as aforementioned. Additionally, it is necessary to review the MSW Planning of Rio de Janeiro in order to meet the needs of the Brazilian National Plan, so it could be approved guiding sustainable city policies. 
Today, the private sector has been applying collaborative or sharing economy, that enables the optimization of resources by the redistribution, sharing and reuse of excess capacity in goods and services, thus reducing wastes. Returning and reusable products, and the replacement of non eco-friendly products are necessary measures for waste prevention. Technologies, as internet and apps, are the key for the implementation of this kind of peer-to-peer economy. In London, for example, the foldable water bottle and the mobile app shows the location of drinking fountains, thus reducing the purchase of mineral water in plastic and disposable bottles (OHYO, 2015). Renting things are also a way to use the collaborative economy. For instance, development of websites to rent gadgets rarely used as electric drill, camping tent etc also contributes to waste reduction.

Garmerman, Brecher and Dardia (2015), carried out a study in the largest US cities, and have shown that the most effective way to reduce the generation of urban solid waste is the taxation by volume produced, i.e., the costs could suffer a variation, so, people could be more committed with the waste reduction/prevention. Therefore, the implementation and economic feasibility is corroborated by this study, that suggests its application in the city of Rio de Janeiro for residential units. It is worth mentioning that in Rio de Janeiro, commercial units (companies, stores, etc) are already charged according to the waste volume produced. This system has been effective not only in US, but also in European cities, since it decreases the waste volume sent to disposal plants/ landfills.

Summing up, there is an increasing concern about the quantity and quality of waste reduction. However, the focus of this study is the source, the reduction of solid waste generation, i.e., waste prevention - always highlighting that such measure must be accompanied by regulations, waste sorting collection, and especially people's behavior towards this issue, once the waste generation begins and ends with consumers/people's attitudes.

\section{Keywords}

National solid waste policy; Enviromental education; urban solid waste; waste reduction. 


\section{Sumário}

1. Introdução 20

2. A questão da produção de resíduos sólidos e a legislação vigente 24

2.1. A sociedade de consumo e o desequilíbrio do ecossistema 24

2.2. A Política Nacional de Resíduos Sólidos e suas principais contribuições 31

2.2.1. A erradicação dos lixões em atendimento à legislação vigente $\quad 39$

2.2.2. O fim do lixão de Gramacho e o cumprimento da PNRS 41

2.2.3. A importância da educação ambiental na gestão dos resíduos sólidos 44

3. A experiência na gestão de resíduos sólidos urbanos - Tendência Internacional - Caso Nova lorque

3.1. Gestão dos resíduos sólidos da cidade de Nova lorque 48

3.2. O Plano de Gerenciamento de Resíduos da cidade de Nova lorque - seus objetivos e suas iniciativas

4. A experiência da gestão de resíduos sólidos urbanos- Tendência Nacional - Caso Rio de Janeiro

4.1. Plano Municipal de Gestão Integrada de Resíduos Sólidos - PMGIRS

4.2. Destinação dos resíduos sólidos gerados na cidade:

CTR-Rio - Seropédica

4.3. Taxa de Coleta Domiciliar de Lixo

74

4.4. Objetivos do PMGIRS do Rio da Cidade do Rio de Janeiro 77

4.6. Ações da Prefeitura de acordo com o PMGIRS 78

4.7. Diretrizes da Política Municipal de Gestão Integrada de Resíduos Sólidos do Rio de Janeiro

4.8. Metas até final dos anos de 2013, 2016 e 202089

5. Considerações Finais 90

6. Referências Bibliográficas 


\section{Lista de figuras}

Figura 1: Mapa da cidade do Rio de Janeiro dividido pelas cinco áreas de planejamento

Figura 2: Formas de coleta de RSU no Rio de Janeiro

Figura 3: Composto feito pela Comlurb 80

Figura 4: Área reflorestada com a utilização do composto

Figura 5: Fabricação de equipamentos públicos a partir da casca do coco 81

Figura 6: Localização do aterro de Seropédica 


\section{Lista de tabelas}

$\begin{array}{ll}\text { Tabela 1: Tipos de obsolescência } & 28\end{array}$

Tabela 2: Custo de disposição final na Cidade de Nova lorque 52

Tabela 3: Massa coletada per capita em relação à pop. urbana 69

Tabela 4: Percentual de resíduos públicos e domiciliares coletados em 2013

Tabela 5: Frequência de atendimento da população 71

Tabela 6: Despesas com Aterro Sanitário de Seropédica 74

Tabela 7: Relação Receita e Despesa da Comlurb 77

Tabela 8: Metas do PMGIRS 89

Tabela 9: Cobertura da Coleta Seletiva no Rio de Janeiro 95

Tabela 10: Reciclagem no Rio de Janeiro 95 


\section{Lista de abreviaturas e siglas}

ABRELPE - Associação Brasileira de Empresas de Limpeza Pública e Resíduos Especiais

AMJG - Aterro Metropolitano de Jardim Gramacho

AP - Área de Planejamento

BNDES - Banco Nacional de Desenvolvimento Econômico e Social

CBC - Citizens Budget Commission

CEMPRE - Compromisso Empresarial Para Reciclagem

COMLURB - Companhia Municipal de Limpeza Urbana

CONAMA - Conselho Nacional de Meio Ambiente

CONSEMA - Câmera Técnica de Resíduo Sólido do Conselho Municipal de Meio Ambiente

CTR - Central de Tratamento de Resíduos

ECO-92 - Conferência Internacional sobre Meio Ambiente e Desenvolvimento Sustentável

ETR - Estação de Tratamento de Resíduos

FCA - Fundo de Conservação Ambiental

GEE - Gases do Efeito Estufa

IBGE- Instituto Brasileiro de Geografia e Estatística.

IPCA - Índice de Preço ao Consumidor Amplo

IPTU - Imposto Predial e Territorial Urbano

MDL - Mecanismo de Desenvolvimento Limpo

ONG - Organização Não Governamental

ONU - Organização das Nações Unidas.

PAYT - Pay as You Throw

PE - Polietileno 
PET - Teraftalato de Polietileno

PMGIRS - Plano Municipal de Gestão Integrada de Resíduos Sólidos

PNEA - Política Nacional de Educação Ambiental

PNRS - Política Nacional de Resíduos Sólidos

PVC - Cloreto de Polivinila

RCC - Resíduos da Construção Civil

RDO - Resíduo Domiciliar

REDUC - Refinaria de Duque de Caxias

RPU - Resíduo Público

RSU - Resíduos Sólidos Urbano

RTD - Resíduos Tóxicos Domiciliares

SCO - Sistema de Custo de Obras

SECONSERVA - Secretaria Municipal de Conservação e Serviços Públicos

SINIR - Sistema de Informação sobre Gestão de Resíduos Sólidos

SMAC - Secretaria Municipal de Meio Ambiente

SNIS - Sistema Nacional de Informações sobre Saneamento

TCL - Taxa de Coleta domiciliar de Lixo

UFRJ - Universidade Federal do Rio de Janeiro

UNEP - United Nations Environment Program

USEPA - United States Environmental Protection Agency 


\section{1. \\ Introdução}

O modelo atual de desenvolvimento econômico brasileiro associado ao crescimento da população e a mudança na forma de consumo ocorrido nas últimas décadas caracteriza a sociedade contemporânea como economia do descarte, segundo Brown (2003), colaborando para a geração extrema de resíduos sólidos urbano (RSU). De acordo com o relatório anual da Associação Brasileira das Empresas de Limpeza Pública e Resíduos Especiais - ABRELPE, em 2013, foram geradas 209.280 toneladas de resíduos por dia no Brasil, fator que consideramos alarmante, tendo em vista que a forma de descarte e destinação final, ainda é um desafio a ser vencido, por conta da falta da efetiva implantação em todo território nacional de uma política de gestão integrada de resíduos adequada e consoante com a legislação vigente.

Sendo assim, atualmente a geração excessiva destes resíduos é um dos desafios ambientais na pauta dos municípios brasileiros, pois todos os materiais ou produtos, sejam eles orgânicos ou inorgânicos ${ }^{11}$ ao final do seu ciclo de vida, embora sejam rejeitos serão classificados como resíduos sólidos, portanto, exigindo da sociedade como um todo a necessidade de aplicação de tecnologias e mudanças no comportamento do descarte.

Portanto, o gerenciamento dos resíduos sólidos urbanos torna-se uma peça fundamental para o desenvolvimento sustentável das cidades. O manejo inadequado dos resíduos, e sua destinação final a locais não controlados, podem acarretar sérios problemas ambientais, passivos que podem levar anos para serem remediados, e sociais já que favorece a atividade de catação ${ }^{12}$ sem que haja qualquer zelo pela saúde humana.

O governo brasileiro diante deste desafio complexo que envolve diferentes segmentos da sociedade, e por não se tratar exclusivamente de uma questão ambiental, mas também econômica e social, sancionou em agosto de 2010 a

\footnotetext{
${ }^{11}$ Material orgânico: de origem biológica, como restos de alimentos e bebidas, plantas e animais mortos. Material inorgânico: produtos manufaturados como os sacos plásticos, embalagens, cadeiras, entre outros.

${ }^{12}$ Atividade desenvolvida por indivíduos no recolhimento de materiais reciclados como forma de fonte de renda.
} 
Política Nacional de Resíduos Sólidos - PNRS, um arcabouço jurídico necessário e fundamental, pois os conflitos de interesses surgem e é preciso uma solução. Nesta lei, a união entre o empresariado, a sociedade civil e a gestão pública é extremamente relevante para a gestão responsável dos resíduos gerados em cada um dos municípios brasileiros (BRASIL, 2010).

Nosso trabalho é um esforço teórico que pretende apontar medidas possíveis de não geração de resíduos sólidos urbanos não somente para atender o que determina a legislação vigente, mas como uma das alternativas sustentáveis de gestão municipal da cidade do Rio de Janeiro e para tanto, faremos um estudo comparativo entre duas cidades - Rio de Janeiro e Nova Iorque, através da análise dos planos municipais no sentido de levantar as melhores práticas e alternativas socioeducativas na busca da mitigação de geração de resíduos por parte da população carioca.

Nesse sentido, o objetivo é deixar de trabalhar na solução do descarte dos resíduos, e nas consequências da poluição, para propor uma abordagem a partir da não geração e redução de resíduos, estratégia considerada essencial para uma gestão eficiente. Portanto, pretendemos propor uma série de medidas que vislumbre a busca pelo consumo consciente através da perspectiva da educação ambiental crítica, o combate ao desperdício, o reuso de produtos, a reciclagem de materiais, como alternativas para a mitigação dos custos econômicos e ambientais pelo uso mais eficiente da energia e dos recursos naturais.

A escolha da cidade do Rio de Janeiro se mostra pertinente por trabalhar os resíduos ainda de forma bastante conservadora, com baixíssimos níveis de reciclagem e aumento na geração de resíduos por pessoa, mesmo após sancionada a Lei 12.305/ 2010.

A escolha da cidade de Nova Iorque foi definida por ser um município com alta densidade populacional, características físicas semelhantes ao Rio de Janeiro, e ter nas estatísticas grande quantidade de resíduos gerados diariamente, e também por exportar os seus resíduos para outras cidades. A cidade americana apresenta em seu plano várias iniciativas, muitas delas de baixo valor operacional, fáceis de serem implementadas, de âmbito local e objetivando a não geração de 
resíduos ou geração de menos quantidade (PLANYC, 2011), outro motivo que consideramos pertinente para nossa análise.

Portanto, surge a pergunta que pretendemos dar resposta ao final deste trabalho:

Como será possível não gerar ou reduzir a quantidade de resíduos sólidos na cidade do Rio de Janeiro, diante das poucas alternativas apresentadas pela companhia municipal responsável pela gestão dos resíduos sólidos urbanos.

Diante da nossa escolha, a pesquisa realizada foi de cunho bibliográfico, e ocorreu entre os meses de janeiro a abril de 2015. Para a cidade do Rio de Janeiro, além de pesquisarmos nos documentos oficiais produzidos pela empresa responsável pela gestão dos resíduos, realizamos um minucioso acompanhamento das informações sobre o tema, que foram veiculadas na mídia, jornais de grande circulação, programas de televisão, noticiários, seminários entre outros eventos.

Já em Nova Iorque, cidade situada nos Estados Unidos da América, além de realizarmos contato direto com alguns profissionais que estão trabalhando com o tema, através de mensagem eletrônica, também utilizamos a pesquisa de cunho bibliográfico e através da literatura produzida por diversos profissionais da área e da análise dos respectivos planos municipais de gerenciamento, foi possível avaliarmos as propostas e propormos algumas alternativas sustentáveis de não geração de resíduos em consonância com que preceitua a Lei 12305/ 2010 para a cidade do Rio de Janeiro.

A título demonstrar como o estudo foi organizado, informamos que dedicamos a primeira parte para tratar de assuntos relativos a produção desenfreada de resíduos sólidos através do consumo excessivo por parte da população que vem sendo estimulada pelo sistema capitalista que a todo tempo incentiva a economia do descarte conforme relata Brown (2003). Para isto, nos valemos de alguns autores que discutem a questão problematizando os impactos ambientas ocasionados pelo consumo exarcebado. Logo a seguir entramos com a importância da existência da Política Pública da área de resíduos sólidos e os diversos desdobramentos ocorridos após ser sancionada. Dando prosseguimento, 
procuramos apresentar a experiência internacional através da análise do Plano de Gerenciamento de Resíduos Sólidos de Nova Iorque, apresentando seus desdobramentos. Em seguida apresentamos o Plano de Gestão da cidade do Rio de Janeiro e seus respectivos desdobramentos, e já aproveitando para fazer algumas análises comparativas entre uma abordagem e outra.

Por fim, tecemos considerações e análises a respeito de várias áreas de abrangência da proposta de gestão de resíduos da cidade do Rio de Janeiro, bem como a de Nova Iorque e sugerimos ações alternativas com o objetivo da mitigação da produção de resíduos e destinação correta de forma sustentável, buscando assim a reutilização, reciclagem ou compostagem dos produtos, a fim de aumentar a vida útil dos aterros sanitários e preservação dos recursos naturais. 


\section{2. \\ A questão da produção de resíduos sólidos e a legislação vigente}

\section{1. A sociedade de consumo e o desequilíbrio do ecossistema}

Uma das questões a serem abordadas neste capítulo é a necessidade de mudança no padrão de consumo da sociedade moderna, já que este assunto é, de acordo com Baudrillard (2007), uma das causas do aumento significativo da geração de resíduos atualmente no planeta.

Este fator ganha sustentação teórica, pois alguns autores afirmam, como o caso de Bauman (2008), que o modelo econômico vigente, incentiva a produção de bens de consumo e serviço e, principalmente a compra deles, como são indicadores de prosperidade e consequentemente se torna a base para o crescimento econômico de qualquer país.

Neste contexto, o progresso econômico traçado pela sociedade atual desponta como um enorme desafio para o crescimento sustentável. $\mathrm{O}$ avanço da produção mundial de bens e serviços passou de US\$ seis trilhões em 1950 para US\$ 43 trilhões em 2000, causando uma devastação ambiental numa proporção que dificilmente alguém teria projetado há décadas atrás ( BROWN, 2003, p. 87).

Na projeção de Brown (2003, p. 87), o crescimento da economia mundial a um índice de 3\% anuais, fará com que a produção de bens e serviços quadruplique ao longo dos próximos 50 anos, atingindo o patamar de US\$ 172 trilhões.

Brown (2003), afirma que no mundo são processados ou consumidos 26 bilhões de toneladas de materiais a cada ano, incluindo 20 bilhões de toneladas composto de: areia, cascalho e pedras para a construção da infraestrutura das cidades como prédios e estradas. Cerca de um bilhão de toneladas de minério de ferro são utilizados na siderurgia; e 700 milhões de toneladas de minério de ouro utilizados para confecção de moeda, jóias e decoração. Nas florestas, são retirados 1,7 bilhão de toneladas de madeira para combustível, aproximadamente um bilhão 
de toneladas para produtos de madeira, e cerca de 300 milhões de toneladas para papel.

De acordo com o Leonard (2011), nos EUA atualmente um terço dos recursos naturais já foram consumidos e possuem atualmente apenas $4 \%$ das suas florestas originais. Com $5 \%$ da população mundial, os americanos consomem $30 \%$ dos recursos naturais e produzem $30 \%$ do lixo mundial. Se todas as pessoas do planeta Terra consumissem nas mesmas proporções que os americanos seriam necessários existir de três a cinco planetas para acomodar este nível de consumo.

Continua Leonard (2011), afirmado que com todo esse consumo exacerbado principalmente nos países desenvolvidos, é necessário explorar os recursos naturais de outros países, conhecidos como países em desenvolvimento ou ainda aqueles que nem sequer chegaram nesta fase. Um dos motivos que $80 \%$ das florestas originais do planeta foram extintas.

Essa compulsão pelo consumo é uma das causas da geração de resíduos sólidos urbanos (RSU), de acordo com Baudrillard (2007), Bauman (2008) e Leonard (2011) . Tal fenômeno tem dominado os cidadãos melhor inseridos no mundo capitalista moderno, que por sua vez desejam cada vez mais adquirir produtos, que são previamente descartados e transformados em resíduos. Para a população abastada é necessário mitigar a voracidade pelo ato de comprar que é em geral observado como sinônimo de felicidade. Segundo Leonard (2011), o consumo é motivado a tal ponto que em países como os EUA é possível verificar que apenas $1 \%$ dos produtos são usados depois de seis meses adquiridos. Isto porque, um cidadão americano atualmente consome duas vezes mais que na década de 1950.

Os produtos passam por um sistema complexo, desde a extração da matéria prima, a manufatura, embalagem, distribuição, uso/consumo e finalmente o descarte. Para os autores, Brown (2003) e Leonard (2011), além destes processos bem definidos no ciclo de vida dos produtos, os bens manufaturados são alvos de interesses de governos e grupos econômicos que incentivam o consumo ignorando o real custo ambiental, ou seja, os recursos que foram utilizados desde a extração até a disposição final do produto. 
Para Brown (2003) e Leonard (2011), esse sistema se encontra em plena crise já que vivemos num planeta com recursos finitos e este foi desenhado como se não houvesse limites.

Baudrilliard (2007), salienta que a sociedade de consumo na qual estamos inseridos é um perfeito exemplo do ato constante de consumir, muitas vezes atingindo a abundância caracterizada pela multiplicação de bens de consumo e serviços. Desta forma, o objeto ou produto não serve apenas para o que se propõe mas uma forma de tornar o individuo reflexo de suas posses. O autor cita ainda os homens da opulência, que no passado se encontravam cercados por outros homens e hoje se encontram rodeados por objetos como uma evidência dessa sociedade de consumo.

Esse consumo compulsivo começou após a Segunda Guerra Mundial (1939-1945), e um dos exemplos a ser citado é do analista econômico, Victor Lebow, que com o objetivo de melhorar a economia dos EUA afirma que:

\footnotetext{
Nossa economia enormemente produtiva exige que façamos do consumo o nosso modo de vida, que transformemos a compra e uso de bens em rituais, que busquemos a nossa satisfação espiritual e do nosso ego no consumo. Nós precisamos que as coisas sejam consumidas, gastas, substituídas e descartadas em um ritmo cada vez mais acelerado". O líder dos conselheiros econômicos do presidente americano Eisenhower disse "o objetivo último da economia americana é produzir mais bens de consumo (LEBOW APUD LEONARD, 2011, p.173).
}

Assim, para manter um sistema linear de prosperidade constante, não bastava operar em novos mercados. Era necessário alavancar as vendas nos já existentes, o que gerou o desenvolvimento de técnicas de incentivo ao consumo com bases tanto na própria concepção dos produtos (obsolescência técnica e programada) quanto nos hábitos dos consumidores (obsolescência percebida). "Quanto mais rápido os produtos deteriorassem, mais cedo seriam descartados e mais rápido a economia cresceria", segundo, Lebow apud por Leonard (2011).

Contudo, a definição de Slade (2006), é bastante apropriada e consolida nosso esforço teórico, pois define a obsolescência de um objeto é definida quando uma de suas características, sejam elas de hardware ou de software, não é mais capaz de cumprir a sua função corretamente. Porém, muitas vezes a obsolescência 
é o resultado de técnicas para limitar a vida útil dos bens manufaturados, ou seja, houve um planejamento por parte do fabricante para tornar o objeto obsoleto. Essa prática tem objetivo, implícito, de incentivar novamente o consumo e a essa estratégia é dado o nome de obsolescência planejada.

Alguns autores como Woolley (2003), Cooper (2004), e Zacar e Ono (2010), afirmam que existem diferentes tipos de obsolescência e estes são abordados por diversos autores. As classificações abordadas foram consolidadas na tabela 1. Com base nesta demonstração é possível observar, a partir do estudo elaborado pelas autoras Zacar e Ono (2010), que algumas categorias se destacam, sendo abordadas pela maior parte dos autores.

Os aspectos técnicos, incluindo a qualidade material e a estrutura física do artefato, bem como os aspectos tecnológicos, são citados por todos os autores consultados. Os fatores econômicos aparecem com um pouco menos de frequência, enquanto que os ecológicos são considerados apenas por um dos autores. Além disso, tanto os fatores psicológicos quanto aqueles relacionados às questões estéticas e aos ciclos de moda são, de alguma forma, levados em conta pela maioria dos autores (ZACAR e ONO, 2010, p. 3). 


\begin{tabular}{|c|c|c|}
\hline Autores & \multicolumn{2}{|c|}{ Tipos de obsolescência } \\
\hline \multirow[t]{3}{*}{ Packard } & Da tecnologia & \\
\hline & Da qualidade & \\
\hline & Do desejo & \\
\hline \multirow{6}{*}{$\begin{array}{l}\text { van Nes, Cramer } \\
\text { e Stevels }\end{array}$} & Técnica & \\
\hline & Econômica & \\
\hline & Ecológica & \\
\hline & Estética & \\
\hline & De recursos & \\
\hline & Psicológica & \\
\hline \multirow[t]{3}{*}{ Woolley } & Por declínio físico & \\
\hline & Por declínio tecnológico & \\
\hline & Pelos ciclos de moda & \\
\hline \multirow[t]{4}{*}{ Cooper } & Absoluta & \\
\hline & Relativa & Psicológica \\
\hline & & Econômica \\
\hline & & Tecnológica \\
\hline \multirow[t]{2}{*}{ Granberg } & Funcional & \\
\hline & Psicológica & \\
\hline \multirow[t]{3}{*}{ Heiskanen } & Por falha & \\
\hline & Por falta de satisfação & \\
\hline & Por mudanças nas necessidades & \\
\hline \multirow[t]{2}{*}{ Kazazian } & Objetiva & \\
\hline & Subjetiva & \\
\hline
\end{tabular}

Fonte: As autoras, com base em COOPER, 2004; KAZAZIAN, 2005; PACKARD, 1963; VAN NES, CRAMER E STEVELS, 1999; WOOLLEY, 2003.

Tabela 1 Tipos de obsolescência

Fonte Zacar e Ono, 2010

A obsolescência da tecnologia ocorre quando um produto se torna ultrapassado, perdendo sua serventia devido a avanços tecnológicos. Quando acontece a obsolescência técnica, o produto não funciona mais apropriadamente. Já a obsolescência econômica ocorre quando novos produtos no mercado são mais viáveis e interessantes na relação custo benefício, ou seja, o custo de aquisição, uso e manutenção são favoráveis. Na obsolescência ecológica, novos produtos no mercado apresentam impactos ambientais menores. A obsolescência estética, por sua vez, acontece quando novos produtos no mercado tem um design mais moderno ou mais de acordo com a moda vigente, de acordo com a percepção do usuário. (ZACAR e ONO, 2010).

Para diversos bens de consumo, mudanças anuais de design se tornaram chave para motivar a compra. Por exemplo, celulares com novos modelos a cada ano que automaticamente desvalorizam o preço do modelo do ano anterior. Com o vestuário feminino ocorre o fenômeno da moda, com shows anuais, estimulam a compra de novos produtos, pois para muitas pessoas, é importante para a autoestima usar roupas que estejam na moda (BROWN, 2003). 
A economia do descarte cresceu durante a última metade do século XX. O descarte de produtos, facilitado pelo apelo da conveniência e o custo artificialmente baixo da energia, é responsável pela quantidade de resíduos que geramos diariamente e pela parcela de materiais que acabam em aterros sanitários (BROWN, 2003).

Otimizar a vida útil dos produtos torna-se uma questão importante para a busca de um consumo consciente e responsável, segundo os autores Manzini e Vezzoli (2002). Algumas estratégias como a intensificação do uso e o aumento da durabilidade são formas de mitigar o impacto ambiental. A primeira, refere-se ao uso coletivo, evitando assim a ociosidade de determinado produto, pois há um compartilhamento entre os usuários. As bicicletas que podem ser alugadas por hora em diversas cidades do mundo, ou sites que possibilitam o empréstimo de produtos são um exemplo para este tipo de estratégia.

O aumento da durabilidade do produto prorroga a necessidade de compra de um novo, consequentemente diminui a demanda pela produção, evita o descarte precoce e a geração de resíduos, além do consumo de recursos naturais no momento de sua manufatura. As lâmpadas tipo $\operatorname{LED}^{15}$ são um exemplo de durabilidade e baixo consumo de energia. Porém é importante destacar a linha tênue entre o aumento da vida útil com a substituição por um novo produto, de acordo com Manzini e Vezzoli (2002). Isso porque nem sempre prorrogar a vida útil de um produto significa menor impacto ambiental. No caso de um bem durável como de uma geladeira, por exemplo, o consumo de energia durante o seu uso pode ser muito mais elevado que um produto lançado recentemente. A substituição por um novo produto neste caso pode ser o mais indicado.

Na visão de Sarlo (2000), a sociedade contemporânea é formada cada vez mais por "colecionadores ao contrário", que desvalorizam os objetos assim que são comprados, o que facilita a cultura do descarte.

\footnotetext{
${ }^{15}$ O LED é um componente eletrônico semicondutor, ou seja, um diodo emissor de luz ( L.E.D = Light emitter diode ), com propriedade de transformar energia elétrica em luz. Tal transformação é diferente da encontrada nas lâmpadas convensionais que utilizam filamentos metálicos, radiação ultravioleta e descarga de gases, dentre outras.
} 
De acordo com Baudrillard (2007), o ciclo vicioso do consumo tem se mostrado permanente. Não dispor determinado produto pode tornar uma pessoa inferior, criar angústias e até mesmo depressões, tornando o ato de consumir cada vez mais necessário

Segundo Leonard (2011), nos EUA a média de produção de resíduos por cidadão é de $2 \mathrm{~kg} /$ dia. Duas vezes mais que na década de 80 . Com todo esse consumo, grande parte é descartada. A parte que é incinerada, ainda pode liberar os gases tóxicos utilizados na produção, afetando a qualidade do ar e a biodiversidade.

Segundo a Universidade das Nações Unidas, em 2012 foram 1,4 milhão de toneladas de lixo eletrônico no Brasil, 7 quilos por habitante. Cerca de 150 milhões de computadores e celulares se tornaram obsoletos, só no Brasil. Cada computador contem quase dois quilos de chumbo, o país enfrenta um sério problema para lidar com 300 milhões de quilos de chumbo. Uma vez em lixões, o chumbo pode infiltrar-se em aquíferos e contaminar os mananciais de água potável. Estes computadores também contêm cerca de 180.000 quilos de mercúrio e 907.000 quilos de cádmio, substâncias altamente poluente quando em contato com o meio ambiente.

Com este cenário, Brown nos diz que,

A economia global atual foi formada por forças de mercado e não por princípios ecológicos. Ao deixar de refletir os custos totais dos bens e serviços, o mercado presta informações enganosas aos tomadores de decisões econômicas, em todos os níveis. Isso criou uma economia distorcida, fora de sincronia com os ecossistemas da Terra, uma economia que está destruindo seus sistemas naturais de suporte (BROWN, 2003, p. 84).

O preço dos produtos muitas vezes são externalizados, já que o custo real de fabricar certos produtos não está capturado no preço. O pensamento imediatista, tanto no lado produtor, quanto no lado comprador, não leva em consideração uma relação de equilíbrio entre a economia e o ecossistema da Terra, tornando um modelo insustentável. Podemos exemplificar essa causa quando não são considerados nos modelos econômicos o custo de perturbação climática favorecendo assim soluções que visam maiores margens de lucro no curto prazo sem pensar nas consequências ambientais em longo prazo. 
Øystein Dahle, vice-presidente aposentado da Esso, citado por Brown (2003), aponta que "o socialismo ruiu porque não permitiu que os preços falassem a verdade econômica. $\mathrm{O}$ capitalismo poderá ruir porque não permite que os preços falem a verdade ecológica." Seria economicamente viável se o mercado informasse o custo total dos produtos e serviços. A questão não é quanto irá custar para realizar essa transformação, e sim quanto custará para a sociedade se não o fizer.

Portanto, não é apenas uma questão de tratamento adequado dos resíduos gerados, mas sim, uma mudança de comportamento na sociedade moderna buscando um consumo mais racional, transparência de informações e hábitos que desencorajem a economia do descarte para que seja possível viabilizar a redução dos resíduos gerados.

Para sustentar nossa argumentação da necessidade da consolidação do consumo sustentável, destacamos a afirmação da United Nations Enviroment Program:

consumo sustentável é definido como "O uso dos produtos e serviços que respondem às necessidades básicas e trazem melhor qualidade de vida, enquanto minimizam o uso de recursos naturais e materiais tóxicos, bem como as emissões de poluentes ao longo do ciclo de vida, de modo a não comprometer as necessidades das gerações futuras" (UNEP, 1995).

\section{2. \\ A Política Nacional de Resíduos Sólidos e suas principais contribuições}

No Brasil, até a oficialização da Política Nacional de Resíduos Sólidos PNRS ocorrer, houve uma série de leis e eventos para a tratativa das questões ambientais, especialmente quanto à temática resíduos sólidos urbanos e seus impactos na sociedade e meio ambiente.

A Portaria 053/1979 do Ministério do Interior condena a forma de disposição final ambientalmente inadequada de rejeitos.

Em 1981, a Lei $\mathrm{n}^{\mathrm{o}}$ 6.938, arbitrava contra o descarte de resíduos em lixões, atividade que passou a ser considerada crime ambiental. 
Em 1991, Projeto de Lei 203 dispõe sobre acondicionamento, coleta, tratamento, transporte e destinação dos resíduos de serviços de saúde.

Conforme aponta Gadotti (2008), em junho de 1992, na Conferência das Nações Unidas sobre Meio Ambiente e Desenvolvimento, conhecida como "Cúpula da Terra" - Eco 92, centenas de líderes de Estado, além de pessoas ligadas ao meio ambiente, participaram do maior encontro mundial sobre a preservação da vida no planeta. Esse encontro tinha como objetivo desenvolver uma estratégia global de proteção do ecossistema do planeta Terra para gerações presentes e futuras. Os países participantes, 175 ao todo, da Conferência produziram diversos documentos, dentre eles o mais importante deles, a Agenda 21 Global. Um programa com base num relatório de 40 capítulos, que constitui uma ampla agenda na tentativa de promover, em escala global, o desenvolvimento sustentável cujo objetivo final é a promoção de um novo modelo de desenvolvimento.

Em 1997, cinco anos depois, em Quioto, foi assinado por mais de 160 países o Protocolo de Quioto. Este protocolo tinha como meta reduzir em média $5,2 \%$ (entre 2008 e 2012) os gases do efeito estufa ${ }^{16}$, causadores do aquecimento global, tendo como referência o ano de 1990.

Em 1999 foi elaborada a Proposição CONAMA 259 intitulada "Diretrizes Técnicas para a Gestão de Resíduos Sólidos". Mas, embora tenha sido aprovada pelo plenário do Conselho, não chegou a ser publicada.

Em 2001 foi realizado em Brasília o $1^{\circ}$ Congresso Nacional dos Catadores de Materiais Recicláveis, com 1.600 congressistas, entre catadores, técnicos e agentes sociais de 17 estados. Eles promoveram a $1^{\text {a }}$ Marcha Nacional da População de Rua, com 3.000 participantes com a finalidade de solicitar uma série de propostas entre elas: o reconhecimento da profissão de catador, melhores condições de trabalho para a maximização dos produtos reciclados e a erradicação dos lixões (BASTOS, 2014, p. 139).

\footnotetext{
${ }^{16}$ Segundo o Anexo "A" do Tratado de Quioto: metano (CH4), dióxido de carbono (CO2), óxido nitroso (N2O), hexafluoreto de enxofre (SF6), além dos perfluorcarbonos (PFCs) e dos hidrofluorcarbonos (HFCs). Esses gases são emitidos na atmosfera pela utilização de combustíveis fósseis, queimadas, pelas chaminés das fábricas, pelo lixo e até pela flatulência do gado.
} 
Em 2003 foi realizado, em Caxias do Sul, o I Congresso LatinoAmericano de Catadores, que propõe novamente a formação profissional para os catadores, fim dos lixões, responsabilização dos geradores de resíduos. Segundo Bastos (2014), apesar da frustração destas demandas, essa organização da categoria no plano nacional, é bastante oportuna para a construção do processo de identificação dos catadores.

Em 2004, de acordo com o governo brasileiro, o Ministério do Meio Ambiente promoveu grupos de discussões interministeriais e de secretarias do ministério para o desenvolvimento de uma proposta que regulamentasse o tema resíduos sólidos. Em agosto do mesmo ano, o CONAMA realizou o seminário “Contribuições à Política Nacional de Resíduos Sólidos” com objetivo de ouvir a sociedade e formular nova proposta de projeto de lei (BRASIL, 2015).

Mas, somente em 2010 é que foi sancionada a Lei Federal $n^{\circ} 12.305$, de 02.08.2010, que institui a Política Nacional de Resíduos Sólidos. Instrumento que tem como objetivo regulamentar a gestão integrada dos resíduos sólidos, abordando temas sociais, econômicos e, claro, ambientais. Trabalha o conceito de gestão compartilhada, já que todas as esferas, empresários, governos e os cidadãos, assumem responsabilidades diante a gestão de resíduos sólidos (BRASIL, 2010).

Em 2012, 20 anos após a maior conferência sobre meio ambiente, é realizado no Rio de Janeiro, a Conferência das Nações Unidas Rio+20 com o objetivo de renovar o compromisso político com o desenvolvimento sustentável, avaliar o progresso e discutir os antigos e novos desafios.

Semanas antes da Conferência Rio+20 é fechado o Aterro Metropolitano Jardim Gramacho, o maior da América Latina de acordo com a Prefeitura do Rio de Janeiro. Segundo Bastos (2014), um marco para a história da cidade, já que foi operado por décadas de forma questionável deixando um passivo social de grande relevância para o município.

O Brasil carecia de um instrumento que regulamentasse a gestão de resíduos sólidos principalmente devido ao aumento na quantidade de resíduos 
gerados. No país, entre 2009 e 2010, a geração de resíduos sólidos registrou um aumento expressivo, seguindo uma tendência dos anos anteriores. Dados da ABRELPE (2010), mostram que a geração total de RSU no país cresceu $6,8 \%$ nesse período, enquanto que a geração per capita aumentou 5,3\%.

Como observado, o processo de formulação de propostas para a instauração de uma legislação sobre resíduos sólidos teve início na década de 1980. Em 1989, foi apresentado o primeiro Projeto de Lei do Senado (PL no 354) sobre o assunto, o qual apresentava regras para acondicionamento, coleta, tratamento, transporte e destinação final dos resíduos de serviços de saúde, e somente 21 anos mais tarde é que foi sancionada a Política Nacional dos Resíduos Sólidos.

A partir de 2004, o Ministério do Meio Ambiente começou a trabalhar na elaboração de uma proposta para a criação de diretrizes gerais aplicáveis aos resíduos sólidos no Brasil e assim instituir uma Política Nacional de Resíduos Sólidos (PNRS). Com o objetivo de estabelecer uma diretriz buscando a sustentabilidade na gestão de resíduos sólidos de forma unificada e, em todo território brasileiro, foi regulamentada pelo Decreto Federal no 7.404/2010, a Lei Federal $n^{\circ}$ 12.305, de 02.08.2010, que institui a Política Nacional de Resíduos Sólidos (BRASIL, 2010). Tal medida se fazia bastante necessária para o enfrentamento dos desafios econômicos, sociais e ambientais decorrentes do manejo inadequado dos resíduos sólidos. E ainda traz obrigações para as três esferas no gerenciamento dos resíduos sólidos: empresários, governos e cidadãos. Segundo Besen (2006), a lei sancionada adiciona conceitos atuais de gestão de RSU e se dispõe a trazer novas ferramentas à legislação ambiental brasileira.

A PNRS prevê a não geração e a redução de resíduos, através de práticas de hábitos de consumo sustentáveis e um conjunto de instrumentos para proporcionar o reuso e o aumento de produtos reciclados assim como o destino ambientalmente correto dos rejeitos. A lei ainda prevê a classificação dos resíduos quanto à sua origem: a) resíduos domiciliares; b) resíduos de limpeza urbana; c) resíduos sólidos urbanos; d) resíduos de estabelecimentos comerciais e prestadores de serviço; e) resíduos dos serviços públicos de saneamento básico; f) resíduos industriais; g) resíduos de serviços de saúde; h) resíduos da construção 
civil; i) resíduos agrossilvopastoris; j) resíduos de serviços de transporte; k) resíduos de mineração.

De acordo com Besen (2006), a instituição da PNRS no cenário político, e sua integração com a Política Nacional do Meio Ambiente e com a Política de Saneamento Básico, torna o país estruturalmente regulamentado para desenvolver a gestão de resíduos sólidos, porém se faz necessária mudanças nos modelos implantados até a presente data.

Os instrumentos da PNRS ajudam o Brasil a atingir uma das metas do Plano Nacional sobre Mudança do Clima, que é de alcançar o índice de reciclagem de resíduos em 20\% em 2015 (BRASIL, 2007, p, 80). Medidas em relação especificamente a não geração ou redução no volume de resíduos sólidos urbanos, objeto de estudo dessa dissertação, são destaques quanto aos princípios e objetivos na PNRS:

Art. $6^{\circ}$ São princípios da Política Nacional de Resíduos Sólidos: I - a prevenção e a precaução (BRASIL, 2010, p.4 );

Art. $7^{\circ}$ São objetivos da Política Nacional de Resíduos Sólidos: II - não geração, redução, reutilização, reciclagem e tratamento dos resíduos sólidos, bem como disposição final ambientalmente adequada dos rejeitos (BRASIL, 2010, p.4 );

Art. $9^{\circ} \mathrm{Na}$ gestão e gerenciamento de resíduos sólidos, deve ser observada a seguinte ordem de prioridade: não geração, redução, reutilização, reciclagem, tratamento dos resíduos sólidos e disposição final ambientalmente adequada dos rejeitos (BRASIL, 2010, p. 6).

Após a Lei 12.305/2010 ser sancionada, fica determinado que os municípios elaborem seus Planos de Gerenciamento de Resíduos Sólidos, com ampla participação social, a fim de traçarem uma estratégia economicamente viável para atingirem a meta de uma gestão de resíduos sólidos sustentável. Portanto, a cobrança de taxas municipais para garantir a sustentabilidade da gestão de RSU, quando o orçamento do município não for suficiente para cobrir os gastos com coleta, tratamento e disposição final é um artificio legal.

Corroborando com nosso raciocínio e argumentação, o Ministério do Meio Ambiente (2015), enfatiza: 
Em 1988, com a promulgação da Constituição Federal, o município passa a ser um ente federativo autônomo, dotado de competências próprias, independência administrativa, legislativa e financeira e, em particular, com a faculdade de legislar sobre assuntos de interesse local; suplementar a legislação federal e a estadual e, ainda, organizar e prestar, diretamente ou sob regime de concessão ou permissão, os serviços públicos de interesse local de caráter essencial (Artigo 30 incisos I, II e V), daí derivando a interpretação de que o município é o detentor da titularidade dos serviços de limpeza urbana e toda a gestão e manejo e dos resíduos sólidos, desde a coleta até a sua destinação final. (BRASIL, MMA, 2015)

Importantes medidas foram estabelecidas na PNRS como a responsabilidade compartilhada pelo ciclo de vida dos produtos: fabricantes, importadores, distribuidores, comerciantes, cidadãos e titulares de serviços de manejo dos RSU têm atribuições na mitigação do volume de resíduos gerados, minimização dos impactos causados à saúde pública e à qualidade do meio ambiente.

A logística reversa dos resíduos, foi outro destaque da PNRS, onde há um conjunto de procedimentos a viabilizar o retorno dos resíduos para as empresas que o fabricaram, importaram, distribuíram ou comercializaram. O objetivo é reaproveita-los em ciclos produtivos ou a empresa providenciar a destinação correta sem causar danos ao meio ambiente. Os produtos envolvidos nessa abordagem são:

- agrotóxicos, seus resíduos e embalagens

- pilhas e baterias

- pneus

- óleos lubrificantes, seus resíduos e embalagens

- lâmpadas fluorescentes, de vapor de sódio e mercúrio e de luz mista;

- produtos eletroeletrônicos e seus componentes.

Conforme previsto no $\S 1$ 1o do artigo 33 da Lei $n^{\circ}$ 12.305, estão incluídas na relação acima, as embalagens plásticas, metálicas ou de vidro de produtos comercializados, bem como aos demais produtos e embalagens, considerando, prioritariamente, o grau e a extensão do impacto à saúde pública e ao meio ambiente dos resíduos gerados (BRASIL, 2010).

Para alavancar a taxa de reciclagem, a PNRS aborda a coleta seletiva que trata do recolhimento de materiais sólidos recicláveis previamente separados na 
própria fonte geradora e da necessidade de forte atuação de empresas, associações e cooperativas de catadores de materiais recicláveis para a gestão dos resíduos sólidos.

A PNRS prevê ainda a criação do Sistema de Informações sobre a Gestão dos Resíduos Sólidos (SINIR), infraestrutura para receber, classificar, consolidar dados referentes a gestão de RSU com o objetivo de apoiar instituições no processo decisório. A sua organização e manutenção se dará em conjunto envolvendo a União, os Estados, o Distrito Federal e os Municípios.

Diversos autores e instituições, como Ramos (1998), Pimenteira (2011), BMU (2013), USEPA (2015), destacam ações hierarquizadas para uma gestão bem sucedida dos RSU. Após a vida útíl do produto, são diversas as possibilidades de tratativa desses resíduos, assim estabeleceu-se uma cadeia de ações a fim de tornar o processo de gestão de resíduos mais eficiente. Essa técnica é utilizada na tentativa de otimizar os recursos e diminuir a quantidade de resíduos destinados aos aterros sanitários ou incineradores. $\mathrm{O}$ entendimento dos conceitos de rejeito e resíduos se tornam necessários para uma melhor absorção da proposta.

Segundo a PNRS, rejeitos são resíduos sólidos que, depois de esgotadas todas as possibilidades de tratamento e recuperação por processos tecnológicos disponíveis e economicamente viáveis, não apresentam outra possibilidade que não a destinação final ambientalmente adequada. Os resíduos sólidos, segundo a PNRS são materiais, substâncias, objetos ou bens descartados resultante de atividades humanas em sociedade e prevê a reutilização, a reciclagem, ou alternativas de tratamento disponíveis. A disposição em aterros - sanitários ou industriais - será uma opção exclusiva para os rejeitos (BRASIL, 2010).

A não geração e a redução na fonte são as primeiras etapas da hierarquia para diminuição do consumo de recursos naturais e energia. Quando a geração do produto não puder ser evitada, se inicia a etapa seguinte, que trata da reutilização ou recuperação do produto. A próxima etapa refere-se à reciclagem, quando o produto deixa de ser um resíduo e é transformado em matéria-prima para novos produtos. Ou a compostagem, quando os resíduos de origem animal ou vegetal, são transformados em um composto orgânico, através de uma variedade de 
processos, capaz de melhorar as características do solo utilizado na agricultura. A recuperação energética aparece como a penúltima etapa, na tentativa de reduzir a utilização dos recursos naturais e de energia. Trata-se da conversão dos resíduos em energia elétrica ou combustível, através de uma variedade de processos, consequentemente reduzindo custos e diminuindo a necessidade de matéria prima. $\mathrm{O}$ uso do biogás ${ }^{17}$ produzido nos aterros pode promover diversos benefícios, estimulando a adoção de práticas de engenharia que maximizam a geração e a coleta do biogás, também reduzindo os riscos de contaminação do meio ambiente. E, finalmente, a última etapa da hierarquia dos resíduos, o aterramento do rejeito quando não há mais opção de aproveitamento nas etapas anteriores (TANSEY, 2015).

A USEPA (2015) sugere e incentiva a utilização das estratégias das primeiras etapas da hierarquia priorizando a diminuição na quantidade de resíduos gerados, reutilização sempre que possível e só então optar pela reciclagem e demais etapas.

Isto porque quando o material ou produto é recusado ou reutilizado, automaticamente outros materiais ou produtos deixam de entrar no fluxo de resíduos do sistema de gestão, gerando mais economia dos recursos naturais e vida útil dos aterros sanitários.

Portanto, o enfoque, ultrapassado, é aquele em que o sistema de gerenciamento RSU tem no controle final dos efeitos seu principal objetivo. Ou seja, atua a partir da geração de resíduos, após o consumo do produto. Enquanto a redução tem como objetivo principal a prevenção, ou seja, buscar alternativas para eliminar a geração de resíduos, ou caso não seja possível, reduzir a geração com o reaproveitamento e tratamento dos resíduos remanescentes.

\footnotetext{
${ }^{17}$ O biogás é um recurso energético renovável que deriva da decomposição de matéria orgânica. formado por gases de efeito estufa (cerca de 55\% de metano (CH4) e $40 \%$ de dióxido de carbono (CO2)), além de nitrogênioe outros gases. A queima do biogás pode ser aproveitada também para a produção de energia elétrica, dentro de determinadas condições técnicas.
} 


\subsection{1.}

\section{A erradicação dos lixões em atendimento à legislação vigente}

Após a lei nacional de resíduos sólidos ser sancionada em agosto de 2010, foi dado um prazo para os municípios se adequarem a nova gestão de resíduos de suas respectivas prefeituras. Isto porque o entendimento era de que quanto menor a quantidade de resíduos gerados, menor seria o volume destinado a lugares incorretos, e consequentemente menor seria o desperdício de energia, e de emissão de gases poluentes e de utilização de recursos naturais.

De acordo com a ABRELPE em 2012, 2.226 municípios, destinavam $58,3 \%$ do lixo gerado para aterros sanitários. No entanto, registrava-se também, que 78 mil toneladas de resíduos por dia tinham destinos desconhecidos e não controlados, ou seja, eram descartados incorretamente. $\mathrm{O}$ pode ser ratificado pelo fato de mais de $60 \%$ dos municípios em agosto de 2014 não terem cumprido em a lei12.305/2010 que determinava que após 180 dias de ter sido sancionada, os municípios não mais deveriam destinar incorretamente resíduos em lixões.

Esses resíduos continuam sendo encaminhados para os lixões, vazadouros a céu aberto onde se decompõem atraindo animais, que transmitem doenças, além de e pessoas, os catadores, que trabalham em péssimas condições de salubridade. Além do resíduo sólido, o lixo produz o chorume, "suco do lixo", líquido gerado pela decomposição do resíduo, que em estado líquido infiltra no solo e contamina o lençol freático.

Os resíduos ao se decomporem também liberam o gás metano $(\mathrm{CH} 4)$, quando dispensado na atmosfera agrava o chamado efeito estufa determinante para o aquecimento global. Como é um gás de fácil combustão apresenta risco de causar pequenas explosões e grandes incêndios colocando em perigo a região.

Muitos destes lixões se tornaram aterros controlados, ou seja, antigos lixões que passaram a ter certo controle e tratamento. Em alguns há o tratamento do chorume e do gás, mitigam alguns impactos ambientais com a aplicação de material inerte na cobertura, evitando a exposição dos resíduos a céu aberto após cada jornada de trabalho, em alguns casos os resíduos são compactados e não costumam dispor de sistema de impermeabilização de solo. 
Apesar das condições bastante precárias nesses lixões ou aterros controlados, a extinção deles divide opiniões. De acordo com Bastos (2014), se por um lado, as condições de trabalho para os catadores são ruins, já que ficam expostos a doenças, por outro lado, este trabalho é o sustento de milhares de pessoas que têm na atividade de catação uma importante fonte de renda para sua família, já que conseguem vender uma grande quantidade de materiais recicláveis.

A exclusão social desta importante classe de trabalhadores é evidente, pois são pessoas que trabalham em condições precárias e sem o reconhecimento do Governo de sua ocupação, apesar da contribuição ambiental na atividade que exercem. Segundo Capucha (2005), a exclusão é resultado de uma desarticulação entre as diferentes partes de uma sociedade e os indivíduos ocasionando uma não participação num conjunto mínimo de benefícios que definem um membro de pleno direito dessa sociedade - inerente a figura dos excluídos - opondo-se claramente a noção de integração social.

De acordo com Ribeiro (2005), pode-se dizer ainda que a exclusão configura-se como um acontecimento multidimensional, como um fenômeno social ou um conjunto de fenômenos sociais interligados que contribuem para a produção do excluído. Simultâneos, ao nível de exclusão, fenômenos sociais diferenciados tais como o desemprego, a marginalidade, a discriminação, a pobreza, entre outros.

A mão-de-obra informal dos catadores espalhados por todos os lixões e aterros controlados do país é a engrenagem para alimentar as indústrias de materiais reciclados. De acordo com o CEMPRE, em 2013, existiam cerca de 800 mil catadores no Brasil, e apenas 3,8\% eram trabalhadores formais. A atividade de catador, embora o Ministério do Trabalho tenha classificado, é uma profissão ainda não reconhecida oficialmente e encontrava-se no Senado, desde 2007, por meio do Projeto de Lei $n^{\circ}$. 618, que visava à regulamentação do exercício das profissões de Catador de Materiais Recicláveis e de Reciclador de Papel (BASTOS, 2014, p. 22). No entanto, em janeiro de 2012, recebeu o veto da Presidência da República sob a alegação de que a lei não atenderia todas as necessidades dos catadores, em especial em relação a direitos e benefícios adicionais. 
Trabalhar a inclusão social destes catadores é uma das prioridades da PNRS, para isso, foram elaboradas ações direcionadas para a criação de instrumentos que permitam um trabalho digno e importante para o reaproveitamento de materiais economizando os recursos finitos do planeta.

Conforme preceitua os seguintes artigos da legislação:

Art. $7^{\circ}$ XII - integração dos catadores de materiais reutilizáveis e recicláveis nas ações que envolvam a responsabilidade compartilhada pelo ciclo de vida dos produtos;

Art. $8^{\circ}$ IV - o incentivo à criação e ao desenvolvimento de cooperativas ou de outras formas de associação de catadores de materiais reutilizáveis e recicláveis;

Art. $5^{\circ} \mathrm{V}$ - metas para a eliminação e recuperação de lixões, associadas à inclusão social e à emancipação econômica de catadores de materiais reutilizáveis e recicláveis; (BRASIL, 2010, p. 4-8).

\subsection{2. \\ O fim do lixão de Gramacho e o cumprimento da PNRS}

O Aterro Metropolitano de Jardim Gramacho (AMJG), considerado o maior vazadouro a céu aberto da América Latina durante trinta anos, iniciou a sua operação no final da década de 70, localizado no bairro Jardim Gramacho no município de Duque de Caxias, às margens da Baía de Guanabara e ocupava uma área de 1,3 milhões de $\mathrm{m}^{2}$ (BASTOS, 2014).

Por anos, o AMJG recebeu cerca de $80 \%$ dos resíduos da cidade do Rio de Janeiro chegando a um total de nove mil toneladas por dia (RIO DE JANEIRO, 2012). Cresceu sobre os manguezais da Baía de Guanabara já que além dos resíduos do município do Rio de Janeiro, recebia os resíduos dos municípios integrantes da Região Metropolitana, como Duque de Caxias, Nova Iguaçu, Nilópolis e São João de Meriti.

O AMJG sofreu intervenções a partir de 1996, sob a orientação técnica da Comlurb, o que permitiu o início do processo de remediação de parte de seu passivo. O Aterro foi licenciado e passou a operar com alguns sistemas de controle. Estes sistemas, desenvolvidos ao longo dos anos, incluem a coleta e tratamento dos gases da decomposição dos resíduos em usina equipada com três 
unidades de queima (flare); a drenagem, equalização e tratamentos biológico e terciário da vazão diária de $1.920 \mathrm{~m} 3$ de chorume coletado, além do monitoramento ambiental e geotécnico do Aterro (RIO DE JANEIRO, 2012).

A Usina de Biogás foi inaugurada no Aterro em maio de 2010 e o projeto passou a ser um modelo para mitigar a emissão de GEE. A primeira fase consistia na captação dos gases capturados por uma rede com 301 poços de captação localizados na superfície do Aterro. Esses gases eram direcionados para queima em alta temperatura na Usina, equipada com três tochas (flare). Com a queima, o gás metano $(\mathrm{CH} 4)$ é transformado em dióxido de carbono $(\mathrm{CO} 2)$, 21 vezes menos nocivo ao meio ambiente que o $\mathrm{CH} 4$. Com isso, cerca de 75 milhões de metros cúbicos de metano por ano deixaram de ser eliminados na atmosfera, contribuindo para reduzir o aquecimento global do planeta (RIO DE JANEIRO, 2012).

A segunda fase, prevista para ser inaugurada em junho de 2013, tratava da utilização do biogás como substituto energético do gás natural utilizado na Refinaria de Duque de Caxias (Reduc) da Petrobrás. A Gás Verde S.A. é a empresa responsável pela captação do gás no Aterro e o seu processamento. $\mathrm{Na}$ usina, instalada no próprio local, o gás passa por uma unidade de purificação até atingir o padrão de qualidade exigido pela Reduc, e em seguida, é escoado em um duto exclusivo de seis quilômetros até a refinaria. É previsto que esse gás, gerado a partir da decomposição dos resíduos, possa suprimir em até $10 \%$ a demanda por gás natural da refinaria de acordo com o Plano Municipal. Segundo a Petrobras, em maio de 2014, a Reduc recebia $49 \mathrm{mil} \mathrm{m³/dia} \mathrm{de} \mathrm{biogás,} \mathrm{o} \mathrm{que} \mathrm{representava}$ cerca de $2,5 \%$ do total do consumo diário de gás.

O encerramento definitivo do Aterro, em 03 de junho de 2012, causou muita polêmica e opiniões divergentes. Muitos acreditavam que o Aterro não mais oferecia riscos ao meio ambiente e poderia ter sua vida útil prolongada já que havia o controle dos resíduos, da emissão de gases e do chorume. Do ponto de vista social, a situação dos catadores era delicada devido às condições de trabalho que se encontravam. DE acordo com Bastos (2014), o encerramento foi motivado principalmente pelo encontro da Conferência das Nações Unidas (Rio+20), realizado entre 13 e 22 de Junho de 2012 no Rio de Janeiro. O encontro reuniu 20 representantes das maiores economias do planeta para discutir desenvolvimento 
sustentável e não seria atraente ter o lixão como vitrine há poucos quilômetros de distância do evento.

A prefeitura alegava que o encerramento das atividades do AMJG era necessária para permitir o cumprimento da meta de redução dos GEE, em 8\%, até o final do ano de 2012, em relação a 2005, definida pelo município do Rio de Janeiro (RIO DE JANEIRO, 2012).

Segundo Bastos (2014), apesar da intervenção municipal em 1996 e o planejamento para encerramento das atividades desde 2004, pouco foi realizado em relação ao processo de inclusão social dos catadores. Os poucos assistentes sociais trabalhando no processo de organização dos catadores em cooperativas tinham como objetivo humanizar a atividade de catação e capacitar os mesmos quanto ao processo legal e comercial. Porém, a equipe reduzida era um desafio para o trabalho com cerca de 1700 catadores cadastrados. A relação com esses trabalhadores era delicada, pois são pessoas expulsas do mercado de trabalho formal e encontraram na atividade de catação uma forma de sustento pessoal e familiar. Bastos em seu livro cita:

Os catadores do território de Jardim Gramacho apresentam atitudes contraditórias em relação ao processo de trabalho que desenvolvem, ora reconhecendo seu valor, ora desqualificando-o, uma vez que têm pouca consciência sobre as etapas que configuram fora do espaço do vazamento de lixo.( BASTOS, 2014, p. 32)

Portanto, devido à pressão da realização da Conferência das Nações Unidas (Rio+20) e uma forma de acabar com o "problema" de forma definitiva, o Governo Municipal assinou um acordo com os representantes dos catadores definindo a quantia de $\mathrm{R} \$ 14.000,00$ (quatorze mil reais) como forma de indenização para cada um dos 1700 catadores cadastrados. Segundo Bastos (2014), talvez a assinatura do acordo de indenização não tenha sido a melhor maneira de promover o processo de inclusão social, mas foi, de acordo com o representante dos catadores, a melhor decisão naquele momento, devido a uma série de fatores que pressionavam a uma tomada de decisão.

De acordo com Bastos (2015), o fechamento do Aterro Metropolitano de Jardim Gramacho foi uma forma de mostrar ao mundo o anseio do município em se tornar uma cidade sustentável, mesmo que não houvesse uma política pública 
clara voltada para reciclagem de RSU que pudesse substituir o trabalho realizado pelos catadores do referido aterro.

O Plano Municipal de Gerenciamento de Resíduos Sólidos do Rio de Janeiro tem como meta identificar até dezembro de 2016, através de órgãos competentes, os eventuais passivos ambientais relacionados aos resíduos sólidos e posteriormente apresentar os planos de remediação cabíveis para serem executado pelo agente causador, quando estes forem identificados (RIO DE JANEIRO, 2012).

\subsection{3.}

\section{A importância da educação ambiental na gestão dos resíduos sólidos}

A educação ambiental pode desempenhar um importantíssimo papel no contexto de desenvolvimento sustentável, principalmente com o propósito de conscientizar a população a respeito da não geração ou redução de resíduos sólidos urbano. No entanto, é necessário observar a educação ambiental sob duas vertentes, segundo Guimarães (2004).

A primeira dela chama-se educação ambiental conservadora na qual são empregados princípios ecológicos gerais, que preferencialmente conduzirão a alterações comportamentais nos indivíduos (LOUREIRO, 2004). No entanto, carece de uma reflexão sobre a sua própria prática, que se limita a campanhas pontuais e estereotipadas, como por exemplo economizar água e separar resíduos, sem uma abordagem mais ampla. Ou seja, não há uma interdisciplinaridade na tratativa que dimensiona a complexidade da relação indivíduo e sociedade, elas apenas reproduzem, pois não refletem a visão da totalidade que impacta as partes (DIAS, 2011).

Portanto, a educação ambiental conservadora apresenta características reativas ou passivas, ou seja, questões que foram impostas como ecologicamente corretas, mas sem um aprofundamento das questões da sociedade contemporânea que se relacionam com determinadas atitudes.

Como exemplo concreto de educação ambiental conservadora, citamos a iniciativa lançada pela Prefeitura do Rio de Janeiro em conjunto com a Comlurb 
no verão de 2014/2015 que com o objetivo de manter as praias limpas espalharam cartazes em pontos estratégicos da cidade, com a frase de efeito: "Todos amam Praia Limpa | Não deixe lixo na areia”. O intuito era conscientizar a população a não deixar os resíduos nas areias contribuindo para não poluição da cidade, bem como para preservação da biodiversidade da região e a saúde pública. Porém, estas ações em educação ambiental são descontextualizadas da realidade socioambiental em questão, pois não produzem o efeito prolongado e internalizado desejado, acaba sendo apenas mais uma campanha sem desdobramentos no processo de não geração e destinação adequada dos rejeitos.

Isto porque acreditamos que a sociedade envolvida no sistema, nem sempre consegue entender criticamente as dimensões, sociais, históricas, biológicas e econômicas dos problemas socioambientais tornando a educação ambiental apenas como um conjunto de práticas que não questionam as verdadeiras raízes dos desafios ambientais da nossa sociedade atual (LOUREIRO, 2004). O exemplo citado acima, mostra claramente que a prática predominante persiste em livrar-se dos resíduos. Não há uma conscientização para o problema ambiental ocasionado. É preciso uma abordagem mais ampla e atualizada, já que o mais importante além da disposição final dos resíduos é sua não geração e/ou sua redução.

Já a segunda vertente é denominada de educação ambiental crítica. Segundo Jacobi (2003), visa uma nova ética ambiental, baseada em ideias sociais e coletivas, na qual foca numa redefinição das relações ser humano-natureza.

Requer uma atitude reflexiva diante dos desafios da crise ambiental atual, como, por exemplo, o crescimento de resíduos sólidos urbano na cidade do Rio de Janeiro (SNIS, 2013). A abordagem da educação ambiental crítica tem como característica uma visão ampla do exercício da participação social. Traz em sua raiz atributos de questionamentos quanto às práticas ingênuas da educação ambiental conservadora e tem como objetivos, além da interdisciplinaridade e visão do todo, um pensamento preditivo capaz de prever futuros problemas socioambientais decorrentes de determinadas atitudes. Como afirma Guimarães: 
"Uma educação ambiental crítica aponta para transformações radicais nas relações de produção, nas relações sociais, nas relações homem-natureza, na relação do homem com sua própria subjetividade num processo de construção coletiva de uma ética, de uma nova cultura, novos conhecimentos. Processos esses assumidos por sujeitos individuais e coletivos que desvelam a necessidade da construção de novo paradigma, um novo modelo de relacionamento com a natureza e de intervenção na história(GUIMARÃES, 2000, p.84)

A Lei Federal 9.795, de 27 de abril de 1999, Política Nacional de Educação Ambiental (PNEA), aborda os fundamentos da educação ambiental crítica, pois esta estimula a compreensão integrada do ambiente em suas múltiplas e complexas relações, envolvendo aspectos ecológicos, psicológicos, legais, políticos, sociais, econômicos, científicos, culturais e éticos. Prioriza garantir a democratização das informações ambientais, estimular e fortalecer uma consciência crítica sobre a problemática ambiental e social. Incentiva a participação individual e coletiva, permanente e responsável, na preservação do equilíbrio do meio ambiente, na defesa da qualidade ambiental como um valor inseparável do exercício da cidadania (BRASIL, 1999).

Carlos Frederico B. Loureiro (2004), também apresenta uma grande contribuição ao tratar sobre a educação ambiental em uma vertente crítica, mostrando a importância da construção de projetos e ações que levem os sujeitos à consciência crítica, partindo sempre da realidade de cada lugar onde se está atuando, ou seja, não trazendo ações de cima para baixo, e sim construindo a partir da realidade de cada área de intervenção.

Neste sentido, entendemos que para tratarmos das questões ligadas ao processo socioeducativo e sustentável voltado para as melhores práticas de disposição final do lixo, bem como construção de projetos para reduzir sua geração, devemos nos valer da educação ambiental crítica por permitir ampliar o conhecimento dos cidadãos, e garantir a construção de uma consciência crítica a partir da sua vivência, o que consideramos essencial e importante para o entendimento da questão preceituada pela legislação ambiental, assim como em função da qualidade da saúde pública e biodiversidade de qualquer município. Para tanto, é preciso uma abordagem de superação no combate aos desafios ambientais impostos pela sociedade contemporânea, ou seja, trabalhar as questões ambientais de forma mais abrangente, envolvendo cenários históricos, sociais, 
ambientais e políticos, que a nosso ver, contribuirão para construir as alternativas sustentáveis na redução dos resíduos sólidos urbanos na cidade do Rio de Janeiro. 


\section{3. \\ A experiência na gestão de resíduos sólidos urbanos - Tendência Internacional - Caso Nova lorque}

\section{1.}

\section{Gestão dos resíduos sólidos da cidade de Nova lorque}

Nossa intenção é apresentar o sistema de gestão de resíduos sólidos da cidade de Nova Iorque, nos Estados Unidos, por se tratar de uma cidade com alta taxa populacional e gerar 14 milhões de toneladas por ano de resíduos (PLANYC, 2011), o estudo de seu plano de gestão de resíduos pode contribuir para uma gestão sustentável de RSU na cidade do Rio de Janeiro já que as cidades apresentam características semelhantes.

Nova Iorque é a cidade mais populosa dos Estados Unidos com cerca de 8.4 milhões de habitantes (CENSUS, 2015), distribuídos numa área de apenas 784 $\mathrm{km}^{2}$ o que a torna uma cidade com uma densidade demográfica bastante elevada. Em 2010, a cidade tinha uma densidade populacional de 27.532 pessoas por quilômetro quadrado, tornando-a a mais densamente povoada entre todas as cidades com mais de 100.000 habitantes nos Estados Unidos.

A cidade encontra-se no extremo sul do estado de Nova Iorque, na foz do Rio Hudson. Grande parte da cidade está em três ilhas: Long Island, Manhattan e Staten Island. Apenas a região denominada Bronx está localizada no continente. O município é banhado a leste pelo Oceano Atlântico.

Todos os dias são gerados cerca de 40 mil toneladas de resíduos na cidade de Nova Iorque. É necessário uma frota de 6000 caminhões para o recolhimento destes resíduos que são distribuídos nas 5 regiões da cidade (Bronx, Brooklyn, Manhattan, Queens e Staten Island). Uma vez recolhidos esses resíduos são encaminhados para centros de reciclagem ou estações de transferência de Resíduos (ETR) onde estes materiais são transferidos para carretas, barcas ou trens para serem processados e reciclados ou para sua disposição final. Esse sistema complexo de coleta de resíduos tem um grande impacto na sociedade, meio ambiente e economia da cidade (PLANYC, 2011). 
Segundo estimativas da Prefeitura da cidade de Nova Iorque por ano são gerados 1, 66 milhões de metros cúbicos de gases do efeito estufa (GEE) os quais representam cerca de 3\% das emissões totais da cidade, decorrentes dos resíduos sólidos urbanos. Com o crescimento da cidade, o objetivo de reduzir a quantidade gerada de resíduos sólidos urbano se tornou uma prioridade para a equipe responsável pela gestão dos resíduos.

Até 1930, grande parte dos resíduos era destinado a lixões ou simplesmente jogados no oceano. Em 1881 foi criado o primeiro departamento para gerenciar os desafios do lixo que estavam espalhados pelas ruas e associados a problemas de saúde pública e que motivou a inauguração deste centro de controle. Durante grande parte do século XX, milhares de incineradores particulares e uma pequena quantidade de incineradores municipais queimaram grandes quantidades de resíduos da cidade, comprometendo a qualidade do ar devido à escassez de controle nos filtros dos incineradores (PLANYC, 2011).

De acordo com Monteiro (2001), a incineração do lixo é um tipo de tratamento de RSU para diminuir o seu volume, tornando os resíduos absolutamente inertes em pouco tempo, se executado de forma correta. Porém, sua instalação e operação são frequentemente caras, principalmente em razão da necessidade de filtros e aparatos tecnológicos sofisticados para mitigar ou eliminar a poluição do ar provocada por gases produzidos durante o processo de queima dos resíduos.

Na década de 80, a cidade contava além dos incineradores, com os lixões, incluindo o maior do mundo durante muito tempo, denominado Fresh Kills, na região de Staten Island. Porém, naquela época já havia oposição para a criação de mais incineradores e aumento na quantidade de aterros sanitários o que levou a novas regulamentações. Com isso, muitas destas plantas incineradoras foram fechadas ou sofreram algum tipo de upgrade nas tecnologias utilizadas (PLANYC, 2011).

No final da década de 1990, todos os incineradores foram fechados na cidade de Nova Iorque que instituiu um programa de reciclagem para papel, plástico, metal e vidro. Apenas o lixão de Fresh Kills continuava em operação e 
recebia todos os resíduos da metrópole. Grande parte dos resíduos era transportada por barcas saindo das estações de tratamento de resíduos (ETRs). Em 2001, a Prefeitura fechou Fresh Kills devido ao impacto ambiental causado na região e a forte pressão política. Começou então a enviar grande parte dos resíduos recolhidos para estações de transferências privadas concentradas em Bronx, Queens, e Brooklyn.

Em 2006 foi desenvolvido pela Prefeitura de Nova Iorque em conjunto com a população e organizações ambientais o Plano de Gerenciamento de Resíduos Sólidos. O principal objetivo do plano era mapear estrategicamente as melhores rotas de coleta, identificar ETRs em cada uma das cinco regiões da cidade e assegurar que os resíduos não fossem destinados para outras regiões dentro da própria cidade.

O plano reduz o trânsito, poluição sonora e contaminação do ar já que maximiza o uso de barcas e trens para transferir os resíduos para o destino correto, já que há a substituição gradual das carretas por estes meios de transporte. Quando o plano for totalmente implementado reduzirá o número de viagens das carretas até a disposição final em aproximadamente 96 milhões de quilômetros por ano (PLANYC, 2011).

E também é prevista uma redução estimada em 38 mil toneladas de metros cúbicos na emissão de GEE. Esse número é bastante elevado porque os resíduos são transferidos para outras cidades ou até mesmo outros estados. Desde 2006, de acordo com Prefeitura, a cidade de Nova Iorque conseguiu progressos com a introdução do plano: aproximadamente $30 \%$ dos resíduos coletados são transferidos por trens, uma ETR marina já foi inaugurada e outra está em construção, apesar da oposição da comunidade, e um centro de reciclagem no Brooklyn.

Se comparada com décadas passadas, houve progresso nas práticas de gerenciamento de resíduos no município. A cidade não deposita mais seus resíduos no oceano, não encaminha para incineradores e aterros sanitários irregulares e otimizou as rotas eliminando milhares de viagens das carretas. 
Apesar do aumento populacional da cidade, a geração de resíduos per capita diminuiu. Porém os desafios para uma gestão de resíduos sustentável são enormes. Como os aterros sanitários são distantes da cidade e a quantidade de resíduos ainda é muito elevada, a emissão de gases no transporte e o gás metano liberado nos aterros sanitários (apesar dos sistemas de captura) contribuem bastante para o total de emissões de GEE. Atualmente a Prefeitura gasta 1 bilhão de dólares por ano para a gestão dos resíduos sólidos, porém com o aumento da população projetado, estudam alternativas para tornar a gestão mais ecológica e economicamente sustentáveis.

Atualmente, a capacidade de aterros sanitários nas regiões que a cidade já envia está se tornando limitado e o preço por tonelada dos resíduos recebidos também aumentou, obrigando a Prefeitura estudar outras alternativas de descarte. No ano de 2012 foram gastos 124 dólares por tonelada segundo relatórios da Citizens Budget Commission (CBC).

Esta comissão, fundada em 1932, é uma organização sem fins lucrativos, apartidária e tem como objetivo analisar as finanças municipais e propor de forma construtiva mudanças no serviços prestados pela prefeitura da cidade de Nova Iorque.

O programa de investigação da Comissão baseia-se em três princípios fundamentais: atender os interesses dos cidadãos, otimizar os recursos públicos, sejam eles financeiros ou humanos e focar o bem-estar das futuras gerações.

A figura abaixo representa a relação do custo de disposição final por tonelada entre os anos de 1991 a 2011. 


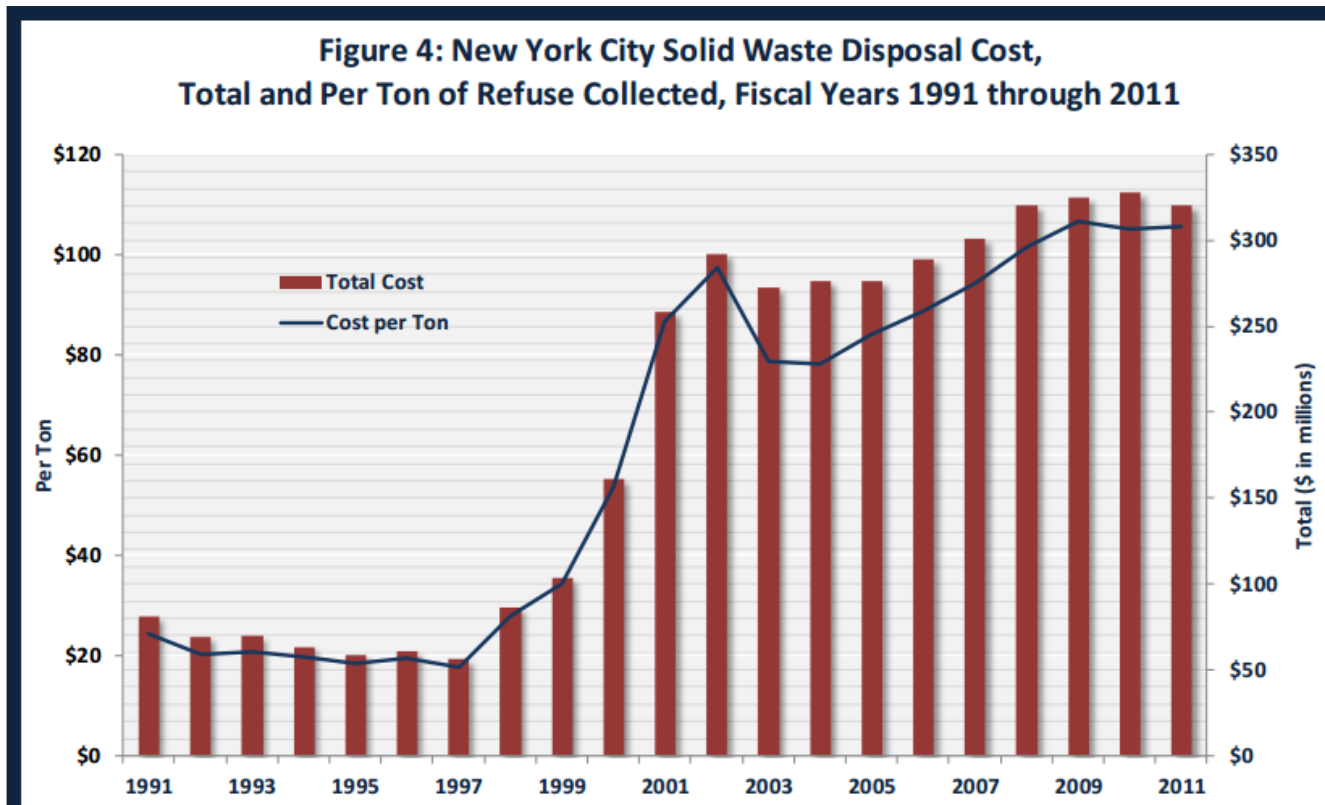

Note: Includes the costs associated with operating waste transfer stations and the Bureau of Waste Disposal but excludes the cost of landfill closure.

Sources: CBC analysis. New York City Office of the Comptroller, Comprehensive Annual Financial Reports, Fiscal Years 1991 through 2011. Cost of landfill closure provided by the New York City Independent Budget Office.

Tabela 2 Custo de disposição final na Cidade de Nova Iorque

Fonte: Taxes In, Garbage Out, 2012

Nota-se um aumento a partir do ano de 2001, pois com a desativação do lixão Fresh Kills, o custo para aterrar os resíduos da cidade de Nova Iorque teve um acréscimo superior a $60 \%$.

O transporte dos resíduos desde a ETR até a disposição final é feito: $45 \%$ por carretas, $32 \%$ por trem, $20 \%$ por barcas. A parte dos resíduos que não é transportado para fora do estado é incinerado na Newark Resource Recovery Center (PLANYC, 2011).

Sendo assim, o governo do município de Nova Iorque com o objetivo de planejar uma cidade mais sustentável criou um plano em 2007, a fim de preparar a cidade para mais um milhão de habitantes, chegando a aproximadamente a 9 milhões de habitantes em 2030. Fortalecer a economia, combater as mudanças climáticas e melhorar a qualidade de vida dos seus moradores e a experiência de seus visitantes eram alguns dos objetivos da criação do plano.

O plano reuniu técnicos e entidades de diversas áreas para trabalhar uma visão de cidade mais verde e com melhor qualidade de vida. O "PlaNYC" visa 10 áreas de interesses: Habitação e Bairros, Parques e Espaços Públicos, Áreas Contaminadas e Subutilizadas, Recursos Hídricos, Fornecimento de Águas, 
Transporte, Energia, Qualidade do Ar, Mudanças Climáticas e Resíduos Sólidos. Neste item, Resíduos sólidos, basicamente, o objetivo é desviar em 75\% a quantidade de resíduos sólidos urbano destinado aos aterros sanitários até 2030.

O plano tem três objetivos principais:

- Preparar a cidade para um aumento significativo da população;

- Reparar e melhorar a eficiência na infraestrutura da cidade de forma a combater as mudanças climáticas;

- Conservar os recursos da cidade, com o objetivo de reduzir a emissão de gases poluentes na atmosfera em $30 \%$.

Segundo o relatório de análise do progresso do plano, emitido em 2013, 97\% das iniciativas já começaram dentro do primeiro ano de implantação. O plano foi atualizado em 2011 e acrescido de 132 novas iniciativas e mais 400 metas especificas.

Devido a elaboração do PlaNYC 2007, diversos outros planos e manuais baseado nessas metas foram criados, para que pudessem mapear potenciais problemas, criar manuais de uso, conservação e criação.

Analisando os desafios do século XXI, pode-se dizer que uma grande meta será combater e conviver de forma resiliente as mudanças climáticas, dentro de uma cidade sócio ambientalmente sustentável (IPCC, 2013). Portanto, todas as 10 áreas de interesse do PlaNYC, contêm medidas para diminuir os impactos das atividade humanas, frente às alterações climáticas, sem desprezar as constantes transformações que são intrínsecas as metrópoles. 


\section{2. \\ O Plano de Gerenciamento de Resíduos da cidade de Nova lorque - seus objetivos e suas iniciativas}

O Plano de Nova Iorque para a gestão de resíduos sólidos urbano tem três áreas de ataque:

1. Redução na geração de resíduos;

2. Reciclagem;

3. Compostagem ${ }^{21}$ e desvio de resíduos orgânico.

Compostos por quatro objetivos que devem ser alcançados através de 13 iniciativas:

\section{Objetivo: Reduzir a quantidade de resíduos através de uma geração menor}

De acordo com o plano, a maneira mais efetiva de reduzir a quantidade de resíduos e não gerá-lo. Para isso, o plano visa capacitar a população a fazer as escolhas corretas quanto ao reuso de materiais. Como por exemplo, incentivar a população a não consumir água em garrafas plásticas, utilizar sacolas de compras retornáveis, diminuir o consumo de papel e doar roupas e utensílios ao invés de descartá-los. Eliminando o desperdício na fonte, o Plano pretende economizar energia, reduzir emissões dos GEE e diminuir os custos para moradores e o comércio.

\section{Iniciativa 1 - Promover oportunidades para prevenir a geração de resíduos}

As garrafas plásticas são novamente citadas, apesar da água da torneira de Nova Iorque ser potável, 50 bilhões de embalagens plásticas são consumidas por ano e somente 13\% destas embalagens são recicladas (PLANYC, 2011). Com isso, o município pretende instalar bebedouros remodelados e estrategicamente posicionados em parques e espaços públicos para aumentar o consumo deste meio evitando assim a compra de novas garrafas de plástico.

Outra forma de redução de resíduo é o uso das sacolas retornáveis. A cidade recolhe anualmente aproximadamente 5,2 bilhões de sacos plásticos.

\footnotetext{
${ }^{21}$ Reciclagem que transforma resíduos orgânicos, de origem animal ou vegetal, em um composto (adubo) capaz de melhorar as características do solo para a prática da agricultura.
} 
Representam 3\% do resíduo domiciliar e custam 10 milhões de dólares para descartar. Apesar de leis recentes exigindo grandes varejistas e lojas nos principais shoppings da cidade aceitarem e reciclarem sacolas plásticas apenas uma pequena porcentagem são recicláveis.

Os novaiorquinos geram mais de 2,5 milhões de toneladas de resíduo de papel, porém reciclam menos da metade dos papeis que poderiam ser reciclados. Portanto, a Prefeitura desenvolveu campanhas para educar quanto ao consumo de papel e as possibilidades de reciclagem. Campanhas com restaurantes e pequenos mercados são realizadas para identificar oportunidades para reduzir a geração de resíduo como, por exemplo, venda a granel de alimentos eliminando a necessidade de embalagens e opções de escolhas dos produtos que acompanham a entrega dos alimentos em domicílio. Criou uma ferramenta que ao se cadastrar no site da Prefeitura (nyc.gov/greenyc), os moradores deixam de receber correspondência indesejadas via mala direta com o objetivo de combater a quantidade de papel gerada nesse processo. Com a medida mais de 3 toneladas de resíduos deixaram de ser enviadas aos aterros sanitários segundo a Prefeitura.

\section{Iniciativa 2 - Aumentar a quantidade de materiais reutilizáveis}

A reutilização de materiais é, segundo o plano, uma forma bastante efetiva para diminuir a quantidade de resíduos. A cidade tem campanhas para encorajar este tipo de atitude. O WasteMatch, é um exemplo de programa bem sucedido. O objetivo é ajudar a novos entrantes no comércio e organizações a acharem equipamentos que não são mais usados por outras instituições, funciona como um classificado sem custo para anunciar. Ativo desde 1997, já ajudou a tirar 25 mil toneladas de materiais dos aterros sanitários de acordo com a Prefeitura. Outro programa é o GrowNYC, uma ONG criada pela Prefeitura, que realiza um evento para doação de roupas e itens de pequeno porte ("Stop N Swap") "Pare e Troque" ( tradução livre). A Prefeitura criou um portal na internet, NYC Stuff Exchange, "Troca de Coisas em Nova Iorque" (tradução livre) com a lista de organizações onde é possível doar, comprar ou vender produtos que não são mais utilizados. Além do programa NYC Materials Exchange Development Program (MEDP), "Progama de desenvolvimento de troca de materias de Nova Iorque" ( tradução 
livre) . Esses esforços retiram milhões de toneladas de materiais dos aterros sanitários.

\section{Objetivo: Aumentar a recuperação de recursos do fluxo de resíduos sólidos}

De acordo com o plano, a cidade de Nova Iorque recicla metade de todo o seu resíduo gerado, porém grande parte é resíduo da construção civil (RCC). Um terço do resíduo doméstico tem potencial para ser reciclado devido a coleta seletiva, porém menos da metade de todo material descartado pelas pessoas são corretamente separados. Além disso, não há coleta seletiva para material orgânico, separando resíduos alimentares de têxteis. Há apenas uma pequena parcela de reciclagem dos resíduos provenientes de jardins.

Ainda segundo o plano, é possível aumentar a quantidade de resíduo reciclável expandindo os itens a serem reciclados, criando novos mercados para os produtos recicláveis e facilitando o ato de reciclar para as pessoas e o comércio. A Prefeitura estuda dar créditos as instituições e comércios que adotaram políticas de reciclagem visando à diminuição na quantidade de resíduo gerado e aumentaram o reuso de materiais.

\section{Iniciativa 3 - Incentivo a reciclagem}

A reciclagem em Nova Iorque acontece desde 1985, quando o resíduo doméstico era separado em, resíduos alimentares, o processamento da gordura fazia produtos de sabão e parte era transformado em fertilizantes ou embalagens de papel e alumínio, pois tinham valor comercial.

Atualmente, apesar dos efeitos positivos da reciclagem como economia de recursos naturais e financeiros e até mesmo geração de renda, a cidade de Nova Iorque tem um potencial de reciclagem ainda não atingido. Com mais de 25 anos de programas de reciclagem de resíduo doméstico, muitos residentes ainda não aderiram a reciclagem, jogando fora materiais que poderiam ser reciclados. Apesar da falta de informação quanto a reciclagem em estabelecimentos comerciais, é sabido pela Prefeitura, que o potencial de reciclagem está longe de ser atingido. Para fomentar a reciclagem no comércio, o município está desenvolvendo um estudo para mapear todo fluxo deste tipo de resíduo. 
Outra estratégia é reconhecer e premiar os programas que incentivam instituições e comércios a expandirem a quantidade de material reciclado e o uso de materiais que foram reciclados. Como exemplos de programas, o Plano destaca o LEED e Green Restaurant Association (restaurantes certificados, com avaliações dos clientes). De acordo com o Plano, alavancar o comércio local dando poder de compra a esses estabelecimentos irá encorajar os mercados emergentes a reciclarem mais materiais.

Quanto ao resíduo domiciliar, tem a estratégica de premiar programas para incentivar a reciclagem doméstica. Como o resíduo domiciliar é uma parte bastante expressiva no total de resíduo gerado pela cidade, acredita-se que aumentando a taxa de reciclagem irá diminuir as emissões de GEE e eliminar parte dos gastos com transporte de resíduos para os aterros sanitários. Seguindo o exemplo do plano, se $60 \%$ do montante papel, metal, vidro e plástico que já fazem parte da coleta seletiva, forem reciclados, haverá uma redução de 100.000 toneladas métricas dispensadas nos aterros.

Além disso, o município pretende melhorar o acesso às informações de reciclagem como, por exemplo, dados estatísticos e de performance, para incentivar a reciclagem, expandir o conhecimento e aumentar a multa para grandes centros que não aderiram as regras de reciclagem também fazem parte do plano.

\section{Iniciativa 4 - Melhorar a conveniência e facilitar a reciclagem}

Segundo o Plano, muitos novaiorquinos querem reciclar porém encontram dificuldades por não haver um padrão de reciclagem. A população acha confuso já que existem diferentes regras de descarte para os domicílios, nos metrôs, centros comerciais, escritório etc. São muitos detalhes como quais embalagens podem ou não ser recicladas. Lixeiras com coleta seletiva eram raras nos parques e nas ruas. Portanto, o plano busca tornar a reciclagem mais conveniente e amigável. Para melhorar o acesso a reciclagem, a Prefeitura instalou 2.190 nova lixeiras seletivas para reciclagem pela cidade e irá aumentar este número com o tempo. Além disso, $25 \%$ dos parques da cidade terão pontos de reciclagem. 
Reciclagem em prédios multi familiar é frequentemente um desafio pela falta de espaço para armazenar e separar os materiais recicláveis. Muitas cidades e a Battery Park City Authority (comunidade planejada na cidade de Nova Iorque) exigem que os prédios residenciais tenham espaços dedicados a coleta seletiva.

A educação para a reciclagem é o foco do plano para aumentar as taxas de produtos recicláveis. Muitos fóruns e campanhas em escolas públicas e particulares e em prédios multi familiares foram feitos com o objetivo de expandir a reciclagem. O programa Resident Green Committees tem informações de como e o que reciclar, além de um guia com 40 dicas sustentáveis. No campo educacional a Prefeitura pretende incorporar um modulo para falar dos benefícios da reciclagem para engajarem os 1.1 milhões de estudantes nas escolas públicas.

\section{Iniciativa 5 - Revisar leis e regulamentações para reduzir resíduos da construção civil}

A indústria da construção civil de Nova Iorque é uma das maiores consumidoras de materiais e gera mais de 7 milhões de toneladas de resíduos da construção civil (RCC) por ano. De acordo com a Prefeitura, a cidade já possui uma ótima taxa de reciclagem e reaproveitamento de materiais. Porém, a Prefeitura vê potencial para crescer ainda mais se houver um melhor manuseio e separação deste tipo de resíduo. A Prefeitura estuda trabalhar as possibilidades com o comércio local e o conselho da cidade para implementar reciclagem obrigatória para certos materiais da construção civil e torná-los opções economicamente viáveis de consumo.

\section{Iniciativa 6 - Criar oportunidades para recuperação de materiais orgânicos}

Na cidade de Nova Iorque aproximadamente 30\% do resíduo doméstico é material orgânico. É composto na maioria das vezes por restos de alimentos, mas também há folhas de jardins e resíduo têxtil, como roupas usadas. Já o resíduo proveniente do comércio, o composto orgânico representa $18 \%$ sendo a sua maioria restos de alimentos. O custo de transportar esse resíduo orgânico, além de alto por conter muita água o tornando mais pesado, também é um fator crítico para as emissões de GEE. Resíduo orgânico, especialmente restos de comida, se 
tornam rapidamente uma fonte de emissão de gás metano quando depositados nos aterros sanitários. Se separados e tratados corretamente podem ser convertidos em fontes valiosas para fins agrícolas e geração de energia. Outros materiais orgânicos como resíduos dos jardins e roupas de algodão, podem também ser compostados ou reciclados. A Prefeitura acredita no grande potencial econômico na reciclagem destes produtos além dos efeitos na redução do transporte deste tipo de resíduo que geram mais congestionamento, ruídos e emissões de gases poluentes na atmosfera.

\section{Resíduos orgânicos}

Os novaiorquinos têm diversas opções de fazer compostagem do resto de alimentos. Muitas comunidades aceitam resíduos alimentares, em pequena escala, para fazer a composta. O programa GrownNYC tem dispensadores orgânicos pela cidade que recebem esse tipo de resíduo. Os moradores de casas com jardins podem usar pequenos containers para compostagem de resíduos orgânicos. Por 18 anos a cidade opera o NYC Compost Project, programa que disponibiliza educação sobre compostagem para os moradores da cidade, organizações sem fins lucrativos e comércios. A Prefeitura pretende expandir os esforços na educação, mensurar e quantificar os esforços realizados, trabalhar com comunidades e parceiros do governo para aumentar a quantidade de dispensadores para resíduos alimentares. Serão lançados mais programas e campanhas para incentivar a compostagem em pequena escala. Também programam relançar a campanha de coleta de resíduo de jardins que representam $4 \%$ do lixo orgânico e esse tipo de resíduo é a matéria prima para fertilizantes de alta qualidade que podem ser usados nos parques da cidade.

Também pretendem expandir a compostagem dos resíduos dos parques, folhas e gramas, gerados pelos parques na cidade. Será instalado em cada uma das cinco regiões uma unidade de compostagem de pequena escala.

Na década de 1990 a Prefeitura lançou um o programa piloto de coleta seletiva, apesar de ter aumentado a taxa de reciclagem nas localidades de baixa densidade da cidade, não era economicamente viável já que a quantidade de resíduo coletada não era grande o suficiente, o que resultava num alto custo de 
coleta por tonelada. Após 20 anos, a Prefeitura irá reavaliar a viabilidade econômica da coleta seletiva para resíduos orgânicos.

Resíduos têxtil representam 7\% do resíduo orgânico, cerca de 190 mil toneladas. Desde 2007, o GrowNYC coleta têxtil em mercados verdes selecionados. A cidade planeja lançar uma parceria publico privada e colocar 50 pontos de coleta em cada uma das cinco regiões para fomentar a reciclagem e o reuso.

\section{Resíduos orgânicos comerciais}

O Hunts Points Food Distribuition Center é o maior centro de distribuição de alimentos dos EUA. Gera aproximadamente 27.400 toneladas de resíduo por ano, $75 \%$ é orgânico e toda essa quantidade é transportada por caminhões para aterros sanitários. O centro é o lugar ideal para operação de um programa recuperação orgânica, já que geraria energia limpa, reduziria o tráfego de caminhões gerando menos poluição.

O óleo utilizado na cozinha é outra fonte orgânica que tem muito potencial energético. Pode ser processado em biodiesel ${ }^{22}$, menos poluente que o tradicional óleo diesel. Porém quando dispensado incorretamente nos ralos, podem entupi-los e entupir a rede de esgoto. Em 2010, foram mais de 14 mil reclamações quanto a entupimentos na rede de esgoto da cidade. Por causa do seu potencial energético, o óleo é uma commodity cobiçada. Na última década o valor do óleo de cozinha aumentou e passou até mesmo ser coletado sem qualquer custo para o comércio. Hoje em metade dos restaurantes da cidade já existe recolhimento do óleo de cozinha.

A Prefeitura tem uma participação na procura deste produto já que obrigou todo sistema de aquecimento da cidade a ter pelo menos $2 \%$ de biodiesel. A Prefeitura pretende continuar com esse tipo de incentivo e planeja desenvolver mais campanhas para educar o comércio, facilitar o licenciamento para os transportadores e permitir o processamento nas ETR.

\footnotetext{
${ }^{22}$ O biodiesel é um combustível biodegradável derivado de fontes renováveis como óleos vegetais e gorduras animais.
} 
Todo ano os restaurantes, mercados, hospitais, centros culturais, estádios e hotéis jogam foram milhares de toneladas de comida. Muitas vezes, se esse resíduo fosse separado na fonte, poderia ser evitado o seu lançamento em aterros sanitários. Apesar de muitos estabelecimentos reconhecerem a importância da separação e a oportunidade de um comércio sustentável, a participação destes centros na compostagem ainda é bastante limitada. Aproximadamente 12.000 toneladas/ano de resíduo alimentar (incluindo Yankee Stadium) são enviados para plantas de compostagem de larga escala, porém estão localizadas a pelo menos $240 \mathrm{~km}$ de distância. A falta de plantas de compostagem perto da cidade é um desafio para a Prefeitura incentivar o reaproveitamento destes materiais.

A Prefeitura pretende reconhecer as instituições que tiverem práticas sustentáveis de gestão de resíduos alimentares. Novas tecnologias como retirar o líquido desse tipo de resíduos no próprio local e a utilização de digestores aeróbicos, sem mal cheiro, nos quais as bactérias comem os resíduos. Esse processo reduz o peso e o volume do resíduo, assim como a eficiência em toda a cadeia de transporte deste resíduo.

Existem muitos programas pilotos de retirada da água dos alimentos em andamento na cidade e a Prefeitura irá incentivar novas tecnologias que aumentem as taxas de diminuição de resíduos.

A Prefeitura lançou em abril 2013 o "Food Waste Challange", programa em parceira com os restaurantes da cidade para diminuir a quantidade de resíduo orgânico. Mais de $25 \%$ dos restos de alimentos foram doados para os bancos de comida da cidade o que contribuiu para que o programa atingisse 2500 toneladas em apenas 6 meses de acordo com a Prefeitura.

\section{Iniciativa 7 - Identificar mercados adicionais para materiais reciclados}

A cidade começou a coleta seletiva em 1989 e a reciclagem de plástico havia começado nesta época. Como resposta as legislações sendo implementadas em municípios e estados nos EUA, a indústria do plástico desenvolveu tecnologias para separar e processar os diversos tipos de plástico, e fazer novos produtos a partir deles. Decisões do que é reciclado dependem muito do mercado, 
eles são desenvolvidos a partir de uma demanda constante por eles. Com o aprimoramento da tecnologia de reciclagem, a Prefeitura irá trabalhar para que mais tipos de plásticos sejam recicláveis encorajando o mercado a fazer isso.

Cerca de $45 \%$ do asfalto removido nas obras de estradas e ruas são reaproveitados, o novo asfalto é produzido nas plantas de reciclagem da própria cidade.

O material drenado dos canais e rios da cidade, para possibilitarem a navegação, também pode ser reaproveitado ao invés de encaminhados para os aterros sanitários, a Prefeitura incentiva o uso destes materiais apesar de não deixar claro no Plano como fazer isso.

\section{Iniciativa 8 - Técnicas de conversão piloto}

O plano de gerenciamento de resíduo sólido tem como objetivo a redução na emissão de GEE alterando a forma de transporte dos resíduos de caminhões por barcas ou trem. Além dos benefícios já citados (congestionamento, poluição do ar etc).

Além destas alternativas, a Prefeitura estuda novas tecnologias para converter resíduo sólido em eletricidade ou combustível que podem sem fontes de receita. Porém é necessário um engajamento de toda a cidade, pois requer um programa robusto de reciclagem. Duas tecnologias, digestão anaeróbica e processamento térmico, são as técnicas mais utilizadas no mundo e possuem um grande potencial nos EUA, de acordo com o Plano. Os digestores anaeróbicos utilizam microrganismos que desmembram os resíduos, produzem o biogás que podem ser utilizados na combustão para gerar eletricidade e composto que servem como fertilizantes. $\mathrm{O}$ processamento térmico utiliza o calor para processar o resíduo sólido e produzir o gás de síntese que também produz energia. Esses gases produzem menos poluição no ar que quando incinerados. Como podem ser comercializados e possuem vantagens ambientais, são atraentes para a sociedade moderna. A Prefeitura estuda usar essas tecnologias de conversão como alternativas para diminuir a quantidade de resíduo. 


\section{Objetivo: Melhorar a eficiência na gestão do sistema de resíduos}

O plano de gerenciamento de resíduo sólido possui estratégias para alcançar o gerenciamento sustentável e a reciclagem dos resíduos sólidos urbanos. É responsável por endereçar a coleta em domicilio, instituições sem fins lucrativos, agências do governo e espaços públicos e o comércio por parte das empresas privadas.

\section{Iniciativa 9 - Reduzir o impacto gerado pela cadeia de gestão de resíduos nas comunidades}

\section{Estações de transferência privadas}

Ao longo dos últimos 30 anos, pequenas comunidades na cidade de Nova Iorque perceberam o impacto do fluxo de gerenciamento de resíduos. As comunidades mais afetadas são as localizadas perto das ETRs (onde os resíduos são transferidos dos caminhões de coleta para as carretas, trens ou barcas). Para trabalhar esses impactos sentidos nessas comunidades, a Prefeitura em conjunto com o conselho, ambientalistas e a própria comunidade aperfeiçoou o plano de gerenciamento de resíduo sólido. Um aspecto bastante trabalhado é a equidade entre as cinco regiões, onde cada área é responsável por gerenciar o seu resíduo, principalmente a coleta e o transporte, evitando que uma área transporte o resíduo para a outra área. Além da equidade, um outro ponto bastante trabalhado no plano é a utilização de barcas e trens para transporte dos resíduos até o seu destino final, substituindo pelas carretas. O plano incentiva o uso das existentes e novas infraestruturas para maximizar o uso de marinas e ferrovias para retirar o transporte de resíduos por ruas e estradas. A Prefeitura pretende estabelecer contratos de longo prazos com empresas para gerenciar o transporte e disposição final dos resíduos coletados em cada região.

Até o momento já foram assinados contratos de longo prazo com empresas para transportar os resíduos por trem de Staten Island, Bronx e nordeste de Brooklyn representando mais de 30\% do resíduo coletado pela cidade. Até 2013 pretendiam construir duas marinas como ETR para exportar o resíduo por barca mas os empreendimentos não foram inaugurados até a conclusão deste trabalho. 
A marina Sims Municipal Recycling Facility foi inaugurada em 2013 e auxilia o transporte de materiais reciclados pela cidade. A planta possibilitou a redução no número de viagens de caminhões em cerca de 368 mil km por ano. Essa estação de transferencia, com contratos de longo prazo, incentiva a reciclagem de produtos comerciais com preços atraentes. Contratos com estações de transferência que tem acesso a malha ferroviária também exigem que o transporte seja feito por trens.

\section{Iniciativa 10 - Melhorar os dados da gestão de resíduos sólidos}

A cidade de Nova Iorque gera mais de 3 milhões de toneladas de resíduos comerciais por ano. Cerca de $40 \%$ destes resíduos são reciclados. Uma das maiores dificuldades de aumentar este percentual é o acesso às informações das empresas privadas responsáveis pela coleta. Em 2004, foi desenvolvido um estudo que serve como base até hoje, mas ainda há falta de dados e detalhes de como as empresas particulares de coleta de resíduos operam.

É sabido que as 150 empresas de coleta de resíduos comerciais mapearam suas rotas de coleta baseados nas necessidades de seus clientes e suas localidades. Como resultado, há uma enorme quantidade de caminhões privados dirigindo grandes distâncias para a coleta de resíduo por toda a cidade. Para um melhor entendimento do sistema, será conduzido um estudo detalhado a respeito da coleta de resíduo comercial, focando na logística, tipos e quantidades de resíduos coletados pela cidade. Baseado no resultado deste estudo será dividido com as empresas privadas as melhores práticas de mercado, recomendações para identificarem oportunidades e aumentar a taxa de reciclagem. O resultado deste estudo estará disponível, inclusive em website, e assim empresas terão mais informações de como este tipo de resíduo pode ser tratado e dispensado.

\section{Iniciativa 11 - Remover materiais tóxicos do fluxo de resíduos}

Materiais tóxicos representam uma ameaça ao meio ambiente e a saúde pública mesmo se forem encontrados em pequenas quantidades. Caso haja um pequeno rompimento em drenos dos aterros sanitários, uma pequena porção de resíduo tóxico pode causar um estrago no aquífero abaixo do aterro. Quando 
queimados, esses resíduos liberam substancias altamente tóxicas no ambiente. Resíduos a base de solventes e corrosivos como ácidos podem causar danos a população. Resíduos tóxicos domiciliares (RTD), pela legislatura da cidade de Nova Iorque, incluem tintas, baterias, fluidos automotivos e produtos que tenham mercúrio, como, por exemplo, os termômetros. Segundo a Prefeitura, a população não tem pleno conhecimento que esses produtos devem ser descartados como resíduos tóxicos. Mais de nove mil toneladas de RTD são enviadas aos aterros sanitários todos os anos. Para o tratamento adequado, a Prefeitura irá expandir oportunidades para o processo de depósito destes resíduos incluindo um evento anual em cada uma das cinco regiões. Segundo estimativa da Prefeitura, $30 \%$ do RTD é tinta e o produto é descartado como resíduo tradicional. Em 2010, a Prefeitura lançou um projeto piloto para fabricantes e revendedores voluntariamente receberem as sobras. Será avaliado a expansão do projeto e não há informações do andamento deste projeto piloto.

Resíduos eletrônicos, desde computadores a pequenos celulares, contêm materiais com alto valor de mercado na indústria de reciclagem, pois possuem cobre e ouro. Porém também são feitos com materiais tóxicos como chumbo e substância anti fogo, bromide. A lei do Estado de Nova Iorque exige que os fabricantes coletem o resíduo eletrônico para reciclarem ou reutilizarem suas peças.

Desde 2015, descartar resíduos eletrônicos como resíduos comuns é ilegal. Através de programas de educação, a Prefeitura pretende aprimorar a conscientização da importância da reciclagem e o reuso em aparelhos eletrônicos retirando assim esses produtos da rota dos aterros sanitários.

Tanto a lei dos resíduos eletrônicos como o projeto das tintas são baseados na premissa que os fabricantes são as empresas mais capacitadas para manusear esses tipos de resíduo.

Programas incentivam os fabricantes de produtos eletrônicos a se anteciparem quanto aos problemas gerados após o fim da vida útil de seus produtos. Portanto, são incentivados a redesenharem os produtos pensando nas possibilidades de uso após o retorno às fábricas. Outras iniciativas como essas 
estão sendo estudadas para impedirem que produtos com materiais nocivos a população e ao meio ambiente venham a ser descartados nos aterros sanitários.

\section{Objetivo: Reduzir a pegada ecológica ${ }^{23}$ nas repartições públicas na cidade de Nova Iorque}

Se a cidade de Nova Iorque pretende ser a líder em práticas de gerenciamento de resíduo, de acordo com o Plano, é preciso que os órgãos municipais sejam o exemplo e efetivamente apliquem as iniciativas. Com mais de 300.000 funcionários e centenas de prédios públicos, os órgãos municipais geram aproximadamente 200 mil toneladas de resíduos por ano. E tem grande potencial de melhora realizando as iniciativas abaixo.

\section{Iniciativa 12 - Revisar as práticas nas áreas de compras dos órgãos municipais}

A cidade gasta atualmente 2.2 bilhões de dólares por ano com materiais que variam desde papel, a monitores de computadores e bandejas para as escolas públicas. Em 2007 a cidade implementou o programa "Compra Ambientalmente Preferível" (CAP), e regras que consideram empresas que tem a preocupação com impactos ambientas e à saúde pública. Esse programa se atenta a geração de resíduo, gasto com energia e água, emissão de GEE, qualidade do ar e presença de substâncias tóxicas.

No curto prazo será implantado um guia para diminuição na quantidade das embalagens e criar iniciativas para os fornecedores a recolherem os produtos quando não forem mais úteis. Além de reduzir a pegada ecológica, haverá uma redução nas despesas.

\footnotetext{
23 De acordo com a ONG World Wide Fund for Nature (2015) pegada ecológica é uma metodologia de contabilidade ambiental que avalia a pressão do consumo da população humana sobre os recursos naturais. Expressada em hectares globais (gha), permite comparar diferentes padrões de consumo e verificar se estão dentro da capacidade ecológica do planeta.
} 


\section{Iniciativa 13 - Melhorar a taxa de desvio nos órgãos municipais}

Um dos maiores desafios para a redução na geração de resíduo é a falta de informação por parte da Prefeitura. Parte do resíduo é coletado por empresas privadas como parte do resíduo comercial e parte da coleta é feita pela própria Prefeitura se misturando com as rotas dos resíduos domiciliares. Como não há um controle em cada uma das repartições públicas da quantidade de resíduo gerado, não é possível mensurar e monitorar os próprios gastos. Será desenvolvido um programa piloto para que esse monitoramento seja possível em todos os prédios da Prefeitura da cidade para que se tenha um maior conhecimento da quantidade de volume gerado. Uma vez que tenham conhecimento dos números e identificarem oportunidades de melhoria irão estabelecer objetivos para aumentar a taxa de resíduo desviado dos aterros sanitários.

Já há um progresso quanto a esse objetivo, escolas públicas têm planos de sustentabilidade que identificam estratégias verdes e um plano completo de reciclagem e educação ambiental.

Uma outra estratégia é identificar produtos que são comprados em larga escala por estabelecimentos públicos e patrocinar eventos para que haja um redesign do produto, propondo um produto alternativo, que seja menos impactante para o meio ambiente, de fácil reciclagem e com menos substância tóxica. Outra alternativa do plano é ter incentivo financeiro para os estabelecimentos públicos diminuírem a geração de resíduos. 
4.

\section{A experiência da gestão de resíduos sólidos urbanos- Tendência Nacional - Caso Rio de Janeiro}

\section{1.}

Plano Municipal de Gestão Integrada de Resíduos Sólidos PMGIRS da Cidade do Rio de Janeiro: desafios para cumprir a legislação

A cidade do Rio de Janeiro, com uma população de 6.323.037 habitantes (IBGE, 2013), possui uma área de $1255 \mathrm{~km}^{2}$, uma densidade demográfica $5038,27 \mathrm{~km}^{2}$. Localizada no sudeste do Brasil é banhada ao sul pelo Oceano Atlântico e a leste pela Baia de Guanabara, faz fronteira com 6 municípios: Duque de Caxias, Itaguaí, Nilópolis, Nova Iguaçu, Mesquita, São João de Meriti.

O Rio de Janeiro conta com oito subprefeituras, que se subdividem em 33 Regiões Administrativas, totalizando 160 bairros. Para fins de planejamento a cidade é dividida em cinco áreas, denominadas áreas de planejamento (AP): AP1 Zona Central, AP2 Zonal Sul, AP3 Zona Norte, AP4 Baixada de Jacarepaguá, AP5 Zona Oeste.

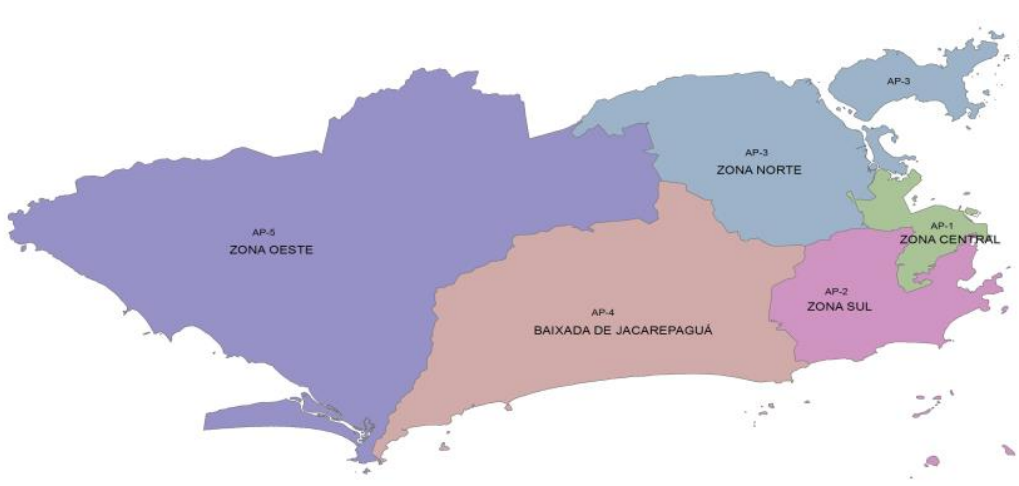

Figura 1: Mapa da cidade do Rio de Janeiro dividido pelas cinco áreas de planejamento Fonte: Comlurb

A Comlurb, Companhia Municipal de Limpeza Urbana da cidade do Rio de Janeiro, criada pelo decreto lei $\mathrm{n}^{\circ} 102$ de 1975 é controlada diretamente pela Prefeitura do Rio de Janeiro, e é constituída juridicamente como uma companhia com o caráter de sociedade de economia mista vinculada à Secretaria Municipal de Obras e Serviços Públicos. É responsável pela coleta domiciliar, transferência, 
tratamento e disposição final do lixo, limpeza dos logradouros públicos, do mobiliário urbano, limpeza e higienização de hospitais municipais e pela preparação e distribuição da merenda escolar (RIO DE JANEIRO, 2015).

Em 2013, de acordo com a Comlurb, foram coletados 3.4 milhões de toneladas (excluindo grandes geradores, como resíduos da construção civil), na cidade do Rio de Janeiro ( SNIS, 2013).

A média de resíduos domiciliar per capita na cidade do Rio de Janeiro em 2013 era de $0,97 \mathrm{~kg} / \mathrm{hab} /$ dia considerando a população de 6.429 .923 habitantes segundo o IBGE, acima da média nacional, que é de $0,64 \mathrm{~kg} / \mathrm{hab} / \mathrm{dia}$ de resíduo domiciliar (SNIS, 2013). Conforme o gráfico abaixo, é possível notar uma tendência de alta na quantidade de resíduo gerado por habitante.

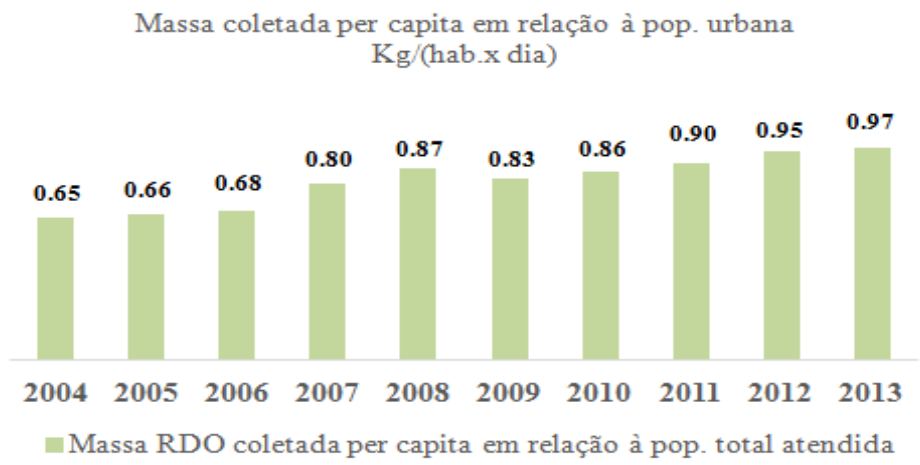

Tabela 3: Massa coletada per capita em relação à pop. urbana Fonte: Sistema Nacional de Informação sobre Saneamento, 2013.

O montante expressivo de 40,99\% corresponde aos materiais passiveis de reciclagem, como metais, plásticos, vidros, papel e papelão. As demais frações correspondem aos orgânicos $(52,68 \%)$ e os restos de madeira e de tecidos, e outros resíduos (6,33\%) (PMGIRS, 2012).

Do total de materiais recicláveis presente no lixo domiciliar, o plástico nas suas diferentes formas Cloreto de Polivinila (PVC), Teraftalato de Polietileno (PET), Polietileno (PE), dentre outras e o papelão respondem por quase $90 \%$ desses materiais (PMGIRS, 2012).

A coleta pública, responsabilidade exclusiva da Comlurb, realizada diariamente, consiste na varrição e recolhimento do resíduo público e de dejetos de animais. A coleta programada, iniciada em 1996, é um serviço sem custo 
adicional oferecido pela Comlurb ao cidadão, voltado à remoção de entulho, de galhadas provenientes de podas de árvores e de bens inservíveis.

\section{Percentual de resíduos coletados em 2013}

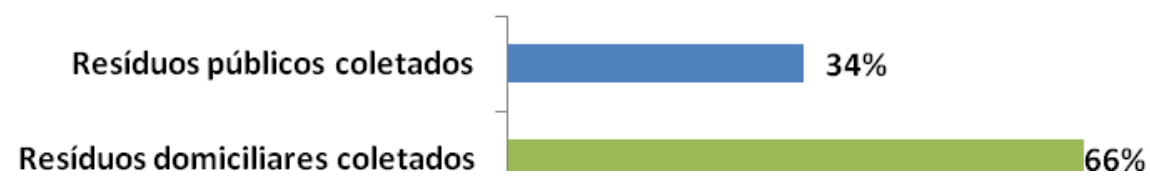

Tabela 4: Percentual de resíduos públicos e domiciliares coletados em 2013

Fonte: Sistema Nacional de Informação sobre Saneamento, 2013.

O Plano Municipal de Gestão Integrada de Resíduos Sólidos (PMGIRS) é o documento que consta o conjunto de ações empreendidas pelo município com o objetivo de buscar soluções apropriadas para seus resíduos sólidos (BRASIL, 2010). A PNRS prevê o conteúdo básico a constar nos PMGIRS, como o diagnóstico dos resíduos gerados (origem, volume, caracterização gravimétrica, meios de destinação e disposição final), a identificação dos geradores, procedimentos operacionais, definição de responsabilidades, entre outros.

As dimensões econômica, ambiental, social e política devem ser abordadas sob a premissa do desenvolvimento sustentável no plano municipal. É uma obrigatoriedade do poder público municipal que, na ausência do documento condiciona o município ao não recebimento de recursos federais para aplicar em melhorias do setor, conforme mencionado na PNRS. Serão portanto, priorizadas para recebimentos de recursos da União, as cidades que buscarem soluções consorciadas voltadas a gestão dos resíduos sólidos e que tenham estruturado a coleta seletiva com a participação das cooperativas de catadores. No município do Rio de Janeiro a Secretaria Municipal de Meio Ambiente (SMAC), é o órgão com a incumbência para desenvolvimento e viabilização do PMGIRS, em conjunto com a Secretaria Municipal de Conservação e Serviços Públicos (SECONSERVA), a qual a Comlurb é subordinada. A SMAC liberou o plano em agosto de 2012 para consulta pública a fim de receber contribuições da sociedade para o seu aprimoramento. Após o período de 30 dias e com as supostas melhorias, o plano foi submetido para sanção do Prefeito e posterior publicação 
para entrada em vigor no município. Durante a elaboração desta dissertação não foram localizados os resultados da consulta pública realizada, e até o momento de sua conclusão o PMGIRS da cidade do Rio de Janeiro não havia sido aprovado segundo o IBGE.

A coleta regular dos resíduos sólidos urbanos gerados, sob responsabilidade da Comlurb, é feita de três formas: domiciliar, pública ou programada. Para a execução dessa atividade a Comlurb tem utilizado novos equipamentos que permitem se adequar as características da cidade.

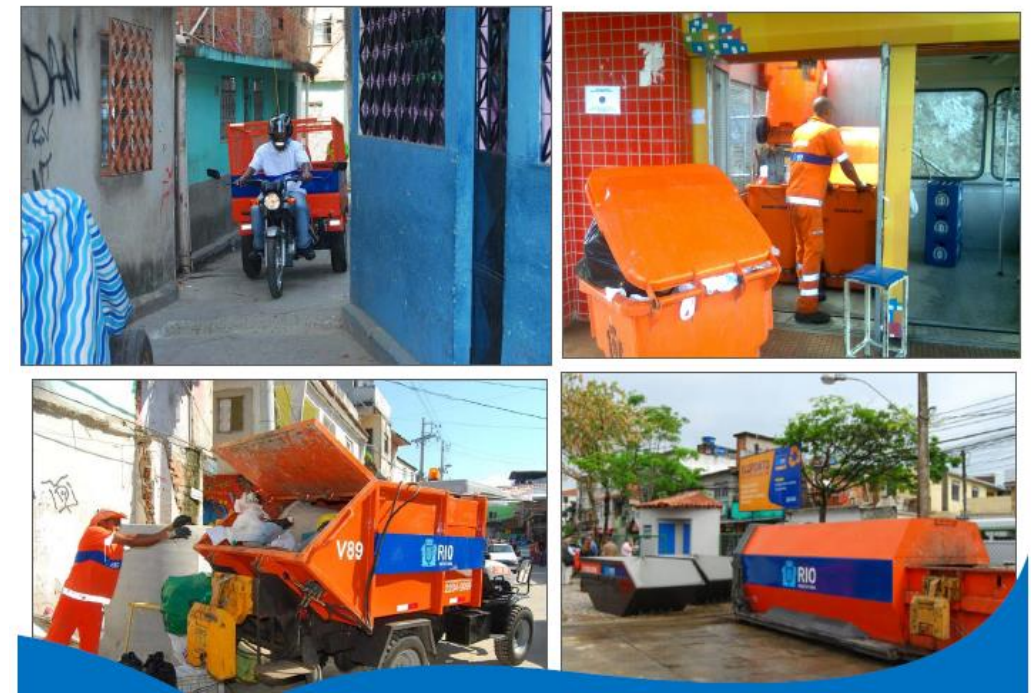

Figura 2: Formas de coleta de RSU no Rio de Janeiro Fonte: Comlurb

A coleta domiciliar trata da remoção e transporte dos resíduos sólidos urbanos devidamente acondicionados, respeitadas as quantidades estabelecidas de 120 litros ou 60 quilogramas diários. De acordo com a SNIS, em 2013, a abrangência atingia $100 \%$ da cidade e a frequência estava distribuída da seguinte forma:

\begin{tabular}{|c|c|c|}
\hline \multicolumn{3}{|c|}{ População atendida, segundo a } \\
frequência
\end{tabular}

Tabela 5: Frequência de atendimento da população

Fonte: Sistema Nacional de Informação sobre Saneamento, 2013. 
No município do Rio de Janeiro, o setor de tratamento de resíduos sólidos urbano da companhia está estruturado para realizar sua atividade de destinação dos resíduos, através das seguintes unidades operacionais: Usina de Reciclagem de Irajá, operando desde 1977, com capacidade de processamento de 520 toneladas/dia de lixo domiciliar, utilizando sistema prévio de trituração, não há esteiras para separação do resíduo e no início de 2012 o percentual de reciclagem era de 0,27\%. A Usina de Reciclagem de Jacarepaguá (ou Vargem Pequena), operacional desde 1993, opera com capacidade de 640 toneladas/dia sendo 310 toneladas/dia de lixo domiciliar, 260 toneladas/dia de lixo público e 70 toneladas/dia de lixo proveniente de grandes geradores; mantém galpões vazios, onde deveria haver a separação do lixo. Apesar da grande estrutura há um contraste com a falta de atividade. Segundo a ex- presidente da Comlurb, Angela Fonti, os condomínios de classe média alta no entorno da usina protestaram contra a presença das instalações e a empresa desativou parte da capacidade. Estação de Transferência do Caju, operando desde 1973, com capacidade de 2.610 toneladas/dia sendo 1.350 toneladas/dia de lixo domiciliar, 1.240 toneladas/dia de lixo público, 210 toneladas/dia de lixo proveniente de grandes geradores e 10 toneladas/dia provenientes de outras fontes. Em 1992 foi inaugurada a usina de reciclagem da Estação do Caju. Estação de Compostagem (km Zero da Rodovia Presidente Dutra) opera com capacidade de 360 toneladas/dia de lixo domiciliar.

De acordo com o Plano da Prefeitura do Rio de Janeiro, a cidade conduziu estudos para identificar soluções ambientalmente sustentáveis para a destinação e tratamento dos resíduos sólidos urbanos gerados no Município. Um motivador para a conclusão destes estudos, de acordo com o próprio plano, era o encerramento programado do AMJG (Aterro Metropolitano de Jardim Gramacho).

Um dos objetivos da investigação era analisar as áreas potenciais para a construção do novo aterro sanitário. Alguns importantes critérios foram levados em consideração para a identificação do melhor local de implantação: zoneamento ambiental, zoneamento urbano; acessos; vizinhança; economia de transporte; titulação da área escolhida; economia operacional do aterro sanitário (jazida, etc.); infraestrutura urbana; bacia e sub-bacia hidrográfica. 
Devido ao grande volume de resíduos gerados pela cidade e a falta de oferta de áreas apropriadas para acondicionamento e tratamento do RSU era inviável a implantação de uma estrutura deste porte na própria cidade (PMIGRS, 2012). O estudo concluiu que o local para receber e tratar os resíduos da cidade do Rio de Janeiro, seria no município de Seropédica a $60 \mathrm{~km}$ do centro do Rio de Janeiro. Apesar do local tenha sido concebido como uma solução exclusiva para a cidade do Rio de Janeiro atualmente se apresenta como uma solução compartilhada entre quatro municípios.

\section{2. \\ Destinação dos resíduos sólidos gerados na cidade: CTR-Rio - Seropédica}

Inaugurada em abril de 2011, a Central de Tratamento de Resíduos (CTR) em Seropédica, construída em uma área de 220 hectares, começou a receber gradativamente os resíduos gerados na cidade do Rio de Janeiro, viabilizando o inicio do processo de desativação do AMJG, em Duque de Caxias.

A CTR de Seropédica é administrada pela empresa Ciclus, a companhia recebeu a concessão da Comlurb para gerenciar o transporte, tratamento e destinação final dos resíduos coletados da cidade do Rio de Janeiro. O local também recebe os resíduos dos municípios de Itaguaí, Seropédica e Mangaratiba.

Para sua operação foi projetado um novo sistema de logística de coleta e transferência de resíduos, o qual contempla sete Estações de Transferência de Resíduos - ETRs (Caju, Tanque, Penha, Bangu, Santa Cruz, Marechal Hermes, Jacarepaguá). A Prefeitura coleta os resíduos e o transporta até uma das sete ETs, depois são transferidos paras as carretas que possuem capacidade de quatro caminhões compactadores, utilizados nas coletas domiciliares. Com a logística definida, o transito de carretas e caminhões é otimizado com o objetivo de diminuir o número de viagens gerando menos congestionamento e emissão de GEE na cidade.

O sistema de impermeabilização inferior do solo na CTR Seropédica é composto de tripla camada de impermeabilização, feita com mantas de polietileno de alta densidade (PEAD), rede de sensores com cerca de 300 eletrodos na célula 
em operação que são ligados a um software que indica qualquer anormalidade no solo em caso de vazamento. O solo ainda conta com camadas de argila compactada.

O chorume, líquido resultante da decomposição dos resíduos, cujo volume diário é cerca de $2.000 \mathrm{~m} 3$, após tratamento, é reaproveitado como água de reuso. Todo o lodo resultante do tratamento, após a desidratação, retorna para o aterro como resíduos sólidos.

O biogás que não for aproveitado na geração de energia ou comercializado é transformado em $\mathrm{CO} 2$ através da queima do próprio (flare). O processo esta dentro das especificações previstas em lei. Como o metano $(\mathrm{CH} 4)$ é 21 vezes mais poluente do que o gás carbônico, o processo gera uma redução significativa de emissões de GEE.

Segundo o relatório de diagnóstico do manejo de RSU, em 2013 a Comlurb apresentou as seguintes despesas referentes a CTR Seropédica:

\begin{tabular}{|c|c|c|c|c|c|c|c|}
\hline \multirow[t]{3}{*}{$\begin{array}{c}\text { CTR } \\
\text { Seropédica } \\
2013\end{array}$} & $\begin{array}{l}\text { Transporte da } \\
\text { ET à dest. final }\end{array}$ & $\begin{array}{c}\text { Disposição final } \\
\text { em aterro }\end{array}$ & $\begin{array}{c}\text { Total por } \\
\text { tonelada ( } \\
\text { Transporte + } \\
\text { disposição fnal) }\end{array}$ & $\begin{array}{l}\text { Quantidade total de } \\
\text { residuos coletados em } \\
2013 \text { pela COMLURB }\end{array}$ & $\begin{array}{l}\text { Valor total gasto (serviços } \\
\text { de transporte da ET até o } \\
\text { aterro + disposição final) }\end{array}$ & $\begin{array}{c}\text { Incidência } \\
\text { sobre a } \\
\text { despesa total } \\
\text { da } \\
\text { COMLURB }\end{array}$ & $\begin{array}{c}\text { Incidência } \\
\text { sobre a } \\
\text { despesa tota } \\
\text { da Prefeitura }\end{array}$ \\
\hline & \multicolumn{2}{|c|}{$R \$ / t$} & $R \$ / t$ & Tonelada & R\$ & $\%$ & $\%$ \\
\hline & RŞ 23.32 & $\mathrm{RS} 30.48$ & RŞ 53.80 & $3,465,186.60$ & RȘ 186,427,039.08 & $14.74 \%$ & $1.01 \%$ \\
\hline
\end{tabular}

Tabela 6: Despesas com Aterro Sanitário de Seropédica Fonte: Sistema Nacional de Informação sobre Saneamento, 2013

\section{3.}

\section{Taxa de Coleta Domiciliar de Lixo}

A taxa de coleta domiciliar de lixo (TCL) é paga em conjunto com a cobrança do carnê anual do Imposto Predial e Territorial Urbano (IPTU)- cujo valor é calculado segundo critérios locacionais, área do terreno e área construída. Essa taxa deve cobrir parte dos custos do sistema de gerenciamento de resíduo sólido domiciliar urbano. O pagamento da taxa não pode ser efetuado de forma separada, impedindo que o contribuinte faça uma distinção entre as taxas e fique inadimplente somente com a TCL. 
Monteiro (2001), destaca que no Rio de Janeiro, a Comlurb efetuou, até 1980, a cobrança de uma tarifa de coleta de lixo, recolhida diretamente aos seus cofres. Porém, em setembro de 1980, o Supremo Tribunal Federal, decidiu que este serviço, por estar relacionado a preservação da saúde pública, era um serviço público essencial, não cabendo, portanto, ser remunerado através de tarifa (preços públicos) mas sim através de taxas e impostos. Em 2000, o município extinguiu a taxa de limpeza urbana e criou a taxa de coleta de lixo, utilizando como base de cálculo a produção de lixo per capita em cada bairro da cidade, e também o uso e a localização do imóvel. Com a aplicação desses fatores, foi possível um diferencial de sete vezes entre a taxa mais baixa e a mais alta cobrada no Município.

A perspectiva da cobrança do tributo é problemática mesmo estando relacionada com a saúde pública, ou seja, a ideia de taxar de forma proporcional a cobrança é citada por Monteiro cujo argumento é:

De um modo geral, a receita com a arrecadação da taxa, que raras vezes é cobrada fora do carnê do IPTU, representa apenas um pequeno percentual dos custos reais dos serviços, advindo daí a necessidade de aportes complementares de recursos por parte do Tesouro Municipal. A atualização ou correção dos valores da taxa depende da autorização da Câmara dos Vereadores, que de um modo geral não vê com bons olhos o aumento da carga tributária dos munícipes. A aplicação de uma taxa realista e socialmente justa, que efetivamente cubra os custos dos serviços, dentro do princípio de "quem pode mais paga mais", sempre implica ônus político que nem sempre os prefeitos estão dispostos a assumir. O resultado dessa política é desanimador: ou os serviços de limpeza urbana recebem menos recursos que os necessários ou o Tesouro Municipal tem que desviar verbas orçamentárias de outros setores essenciais, como saúde e educação, para a execução dos serviços de coleta, limpeza de logradouros e destinação final do lixo. Em qualquer das hipóteses, fica prejudicada a qualidade dos serviços prestados e o círculo vicioso não se rompe: a limpeza urbana é mal realizada, pois não dispõe dos recursos necessários, e a população não aceita um aumento das taxas por não ser brindada com serviços de qualidade. (MONTEIRO, 2001, p.6)

Algumas estratégias poderiam ser tomadas para romper esse impasse de falta de verba para a execução da gestão de RSU. A falta de informação no carnê de cobrança da cidade do Rio de Janeiro é um ponto fraco. Não é discriminada a fórmula e os parâmetros utilizados para calculo do valor da TCL. Além disso, o valor fixo da taxa, independente da quantidade de resíduos gerados é um desestímulo para a população minimizar a quantidade de RSU gerado tornando o sistema injusto. De acordo com estudos realizados pelo BMU (2013), nas regiões 
do país onde a cobrança é realizada pela quantidade gerada de resíduos, assim como é cobrado os serviços de água, energia e gás, esse sistema pode produzir bons resultados em termos de aumento da taxa de reciclagem e redução de resíduos, pois coloca a responsabilidade no usuário.

Neste sistema conhecido internacionalmente como Pay-as-you-throw (PAYT), o usuário passa ter o custo como fator motivador para buscar soluções mais sustentáveis desde o consumo até o descarte. Nos Estados Unidos, de acordo com PlaNYC (2011), em 2006, trinta das 100 maiores cidades do país haviam adotado esse sistema de cobrança para resíduo sólido urbano domiciliar e atualmente são as cidades que apresentam as melhores taxas de produtos reciclados.

Outro aspecto que torna ainda mais desafiador a gestão dos RSUs na cidade do Rio de Janeiro é a falta de transparência quanto as despesas e receitas da Comlurb relativas ao gerenciamento de resíduos sólidos no Município. Apesar dos dados estarem disponibilizados no site do SNIS, estes encontram-se desatualizados e alguns campos sem informação. A Comlurb não faz referencia a disponibilização destes dados no seu site. Por exemplo, não há o valor especificado pela disposição final da tonelada no antigo aterro de Gramacho. Para corroborar com a afirmativa, foi aberta pela Câmera Legislativa do Rio de Janeiro em 19 de março de 2015, uma Comissão de Inquérito Parlamentar para apurar todo o processo de destinação do lixo na cidade assim como o preço cobrado pela tonelada de lixo dispensada no aterro sanitário. É importante que a população saiba que o sistema de manejo de RSU é remunerado pela taxa paga no IPTU e tenha conhecimento das despesas e receitas

Monteiro (2001), esclarece que no Manual de Gerenciamento Integrado de resíduos sólidos está explícito que:

"Em última análise, está na própria população a chave para a sustentação do sistema, implicando por parte do Município a montagem de uma gestão integrada que inclua, necessariamente, um programa de sensibilização dos cidadãos e que tenha uma nítida predisposição política voltada para a defesa das prioridades inerentes ao sistema de limpeza urbana (MONTEIRO, 2001, p10). 
De acordo com relatório de diagnóstico do manejo de RSU do SNIS, a evolução das despesas e receitas per capita nos últimos 10 anos apresenta um acréscimo respectivamente de 55,3\% e 53,69\% se corrigido com Índice de Preço ao Consumidor Amplo (IPCA), de 71,13\% no período entre 2004 e 2013. É possível notar também que nos anos de 2004, 2007, 2011 e 2013 o total arrecadado foi inferior as despesas totais.

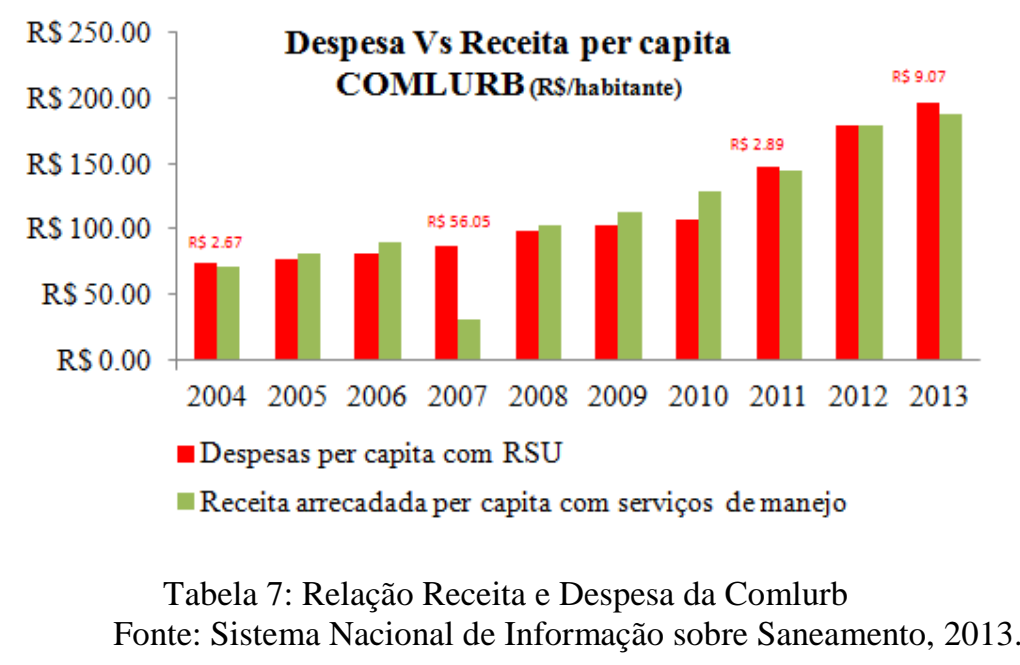

Ainda segundo o SNIS, a incidência das despesas com o manejo de resíduos sólidos urbanos nas despesas correntes da Prefeitura representaram $6,86 \%$ em $2013^{27}$. Este indicador apresenta uma levíssima variação entre o período de 2004 e 2013, inferior a um ponto percentual.

\section{4.}

Objetivos do PMGIRS do Rio da Cidade do Rio de Janeiro.

O Plano Municipal de Gerenciamento de Resíduos Sólidos - PMGIRS da Cidade do Rio de Janeiro tem como objetivo:

- Proteger a saúde pública e a qualidade do meio ambiente;

- Incentivar a coleta seletiva, a reutilização e a reciclagem, garantindo a redução da geração de resíduos sólidos;

- Garantir a adequada disposição final dos resíduos mediante utilização de técnicas ambientalmente sustentáveis e propiciadoras do aproveitamento de energia;

- Definir o papel do setor privado e da sociedade civil na gestão dos resíduos e suas responsabilidades no cumprimento dos objetivos da política de meio ambiente da cidade;

\footnotetext{
${ }^{27}$ Excetuando-se os investimentos.
} 
- Gerar benefícios sociais e a busca da sustentabilidade econômica dos serviços ligados ao gerenciamento de resíduos, promovendo o desenvolvimento sustentável;

- Criar mecanismos de geração de trabalho e de renda promovendo a inclusão social dos catadores de materiais recicláveis;

- Incentivar as parcerias do governo com organizações que permitam otimizar a gestão integrada de resíduos sólidos;

- Garantir a recuperação de áreas degradadas pela disposição inadequada de resíduos sólidos e de rejeitos, pela própria municipalidade ou pelo autor da degradação, quando identificado;

- Garantir o acesso da população a informação, a participação e ao controle social nas questões relativas a gestão integrada de resíduos sólidos;

- Garantir a regularidade, a continuidade, a funcionalidade e a universalidade dos serviços públicos de manejo de resíduos sólidos;

- Incentivar o uso de matérias-primas e insumos derivados de materiais recicláveis e reciclados, bem como o desenvolvimento de novos produtos e processos, com vistas a estimular a utilização das tecnologias ambientalmente saudáveis;

- Garantir que sejam alcançados os percentuais de redução dos GEE estabelecidos pela Lei Municipal de Mudanças Climáticas (Lei no $5.248 / 2011)$ para $2012=8 \%, 2016=16 \%$ e $2020=20 \%($ PMGIRS, 2012, p. 6 - 7).

Diferentemente do Plano de Nova Iorque, o Plano da capital fluminense não apresenta, em cada um dos seus 12 objetivos, como pretende atingí-los. Apesar dos itens serem atuais e estarem de acordo com as leis municipais e federais (PNEA e PNRS), buscando melhorias não só na área ambiental mas também no social, o Plano carece de estratégias mais definidas relacionadas a cada objetivo. A estrutura do Plano de Nova Iorque apresenta em cada um dos objetivos as iniciativas que serão realizadas, tornado clara e objetiva a leitura do Plano.

\section{6.}

\section{Ações da Prefeitura de acordo com o PMGIRS}

A Comlurb é responsável pela operação da coleta seletiva na cidade. Em Janeiro de 2015, operava em 67 bairros dos 160 bairros do município do Rio de Janeiro, porém mesmo nos bairros atendidos o sistema não opera em todas as ruas. O processo de segregação dos resíduos ocorre na fonte geradora, ou seja, nas casas e condomínios onde a população separa o lixo orgânico do lixo seco reciclável. A coleta é feita por caminhão compactador, porta a porta, duas vezes por semana, para impedir o acúmulo e o interesse da população de rua aos materiais separados para a reciclagem. 
Os materiais que são recolhidos se estiverem na rua e acondicionados em sacos plásticos transparentes são: papel, vidro, plástico e metal. Esses materiais são encaminhados para a Usina do Caju onde são separados por 110 cooperados. A quantidade de recicláveis recuperados em 2011 foi de 7.797 toneladas, o equivalente a $4 \mathrm{~g}$ por pessoa/dia (PMGIRS, 2012).

Em 2011, a Comlurb tinha o objetivo de estender o serviço de coleta seletiva a todos os 160 bairros da cidade e promover a inclusão social e produtiva de até 1.500 catadores de materiais recicláveis e garantir o reaproveitamento de $5 \%$ dos materiais potencialmente recicláveis presentes no lixo domiciliar até 2013. O programa de expansão tornou-se viável a partir de um contrato com o BNDES realizado em dezembro de 2010 no qual disponibilizou cerca de 52 milhões de reais.

Parte do recurso do BNDES foi destinado a construção das seis Centrais de Triagem (CTs) (Centro, Bangu, Campo Grande, Penha, Irajá e Vargem Pequena) que serão devidamente equipadas, para recebimento, triagem, armazenamento e comercialização dos materiais recicláveis oriundos da coleta seletiva domiciliar. Projetos de capacitação e apoio na autogestão das novas Cooperativas de Catadores que ocuparão as Centrais de Triagem e a divulgação da iniciativa e conscientização da população também estão incluídos no projeto.

A Prefeitura caberá a cessão das áreas das Centrais pelo período de dez anos, renováveis por igual período, além da ampliação da frota de caminhões de coleta seletiva e estender o serviço de forma adequada a todas as ruas de todos os bairros da cidade.

Na primeira semana do ano de 2014 , foi inaugurada a central de triagem de Irajá (18 meses de atraso de acordo com o plano). A Central foi desenvolvida para receber 20 toneladas/dia de resíduos recicláveis e é responsável pela geração de aproximadamente 200 novos empregos para catadores. Apesar do acordo ter sido firmado em 2010, apenas a central de triagem de Irajá foi inaugurada.

A Prefeitura promoveu, de acordo com o Plano, diversos encontros com os catadores onde foram abordados diversos tópicos do programa, como: o projeto 
das Centrais de Triagem, os equipamentos a serem utilizados nas Centrais, os caminhões a serem usados na coleta seletiva residencial de forma a garantir a qualidade dos materiais, o projeto de identidade visual, visando mantê-los informados e integrados na implantação do projeto.

No Programa de Ampliação da coleta seletiva, o Plano previu uma extensa capacitação dos catadores para a autogestão das Centrais de Triagem, incluindo a gestão financeira e contábil, segurança do trabalho e patrimonial, saúde ocupacional e ambiental, mercado de materiais recicláveis e comercialização em rede.

Em relação a coleta dos resíduos orgânicos realizada pela Comlurb, somente parte destes materiais passam pelo processo de compostagem. De acordo com o Plano, a empresa produz atualmente cerca de $15.000 \mathrm{~m} 3 /$ ano de composto orgânico (processo de transformação da matéria orgânica em fertilizante), conhecido como Fertilurb, proveniente do resíduos orgânicos recolhidos pela coleta domiciliar. O produto é feito na Usina do Caju e usado nas ações de reflorestamento da cidade e no Programa de Reflorestamento e Preservação de Encostas do Município. Quando não são utilizados totalmente, são comercializados. Esse projeto da Prefeitura tem o objetivo aumentar a vida útil dos aterros, diminuir o número de viagens das carretas e diminuir a emissão de GEE contribuindo para a meta estabelecida de redução em $20 \%$ até 2020 na cidade.

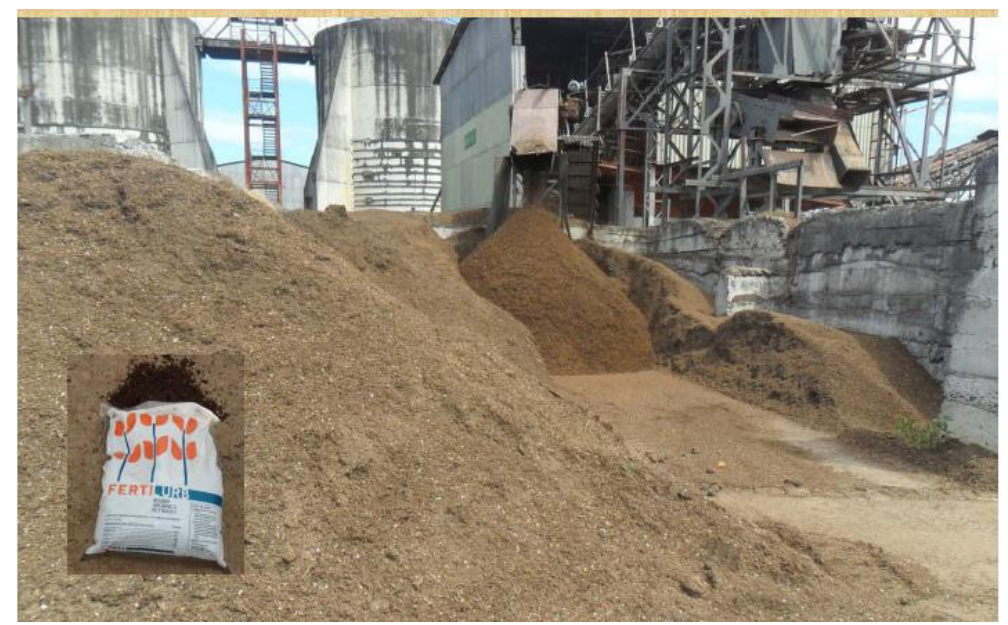

Figura 3: Composto feito pela Comlurb Fonte: Comlurb 


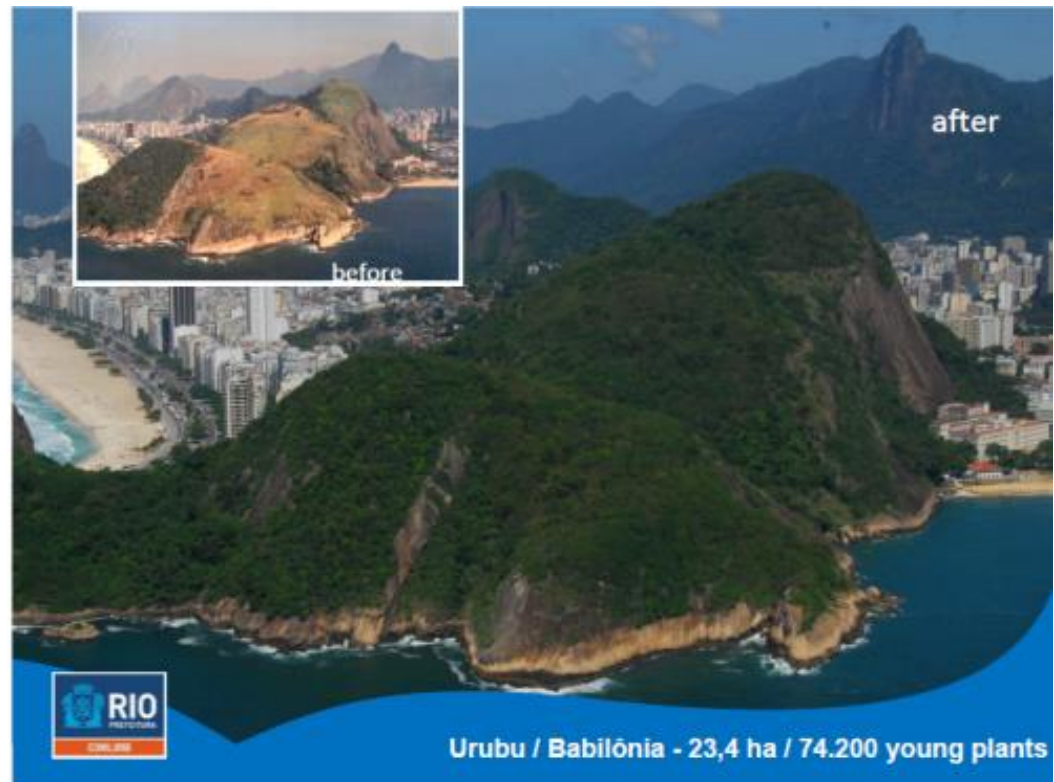

Figura 4: Área reflorestada com a utilização do composto Fonte: Comlurb

O coco verde é um produto consumido nas praias da capital fluminense e a Prefeitura do Rio de Janeiro lançou o Projeto Coco Zero revelado no PMGIRS (2012). Trata-se do reaproveitamento das cascas dos cocos verdes coletados no trecho entre as praias do Arpoador e o Leblon. É a matéria prima para divisórias e pisos industriais, para a fabricação do cepo das vassouras do serviço de limpeza urbana e a fabricação de coletores para utilização nos parques públicos. Aproximadamente 1.000 toneladas de coco foram desviadas dos aterros sanitários municipais.

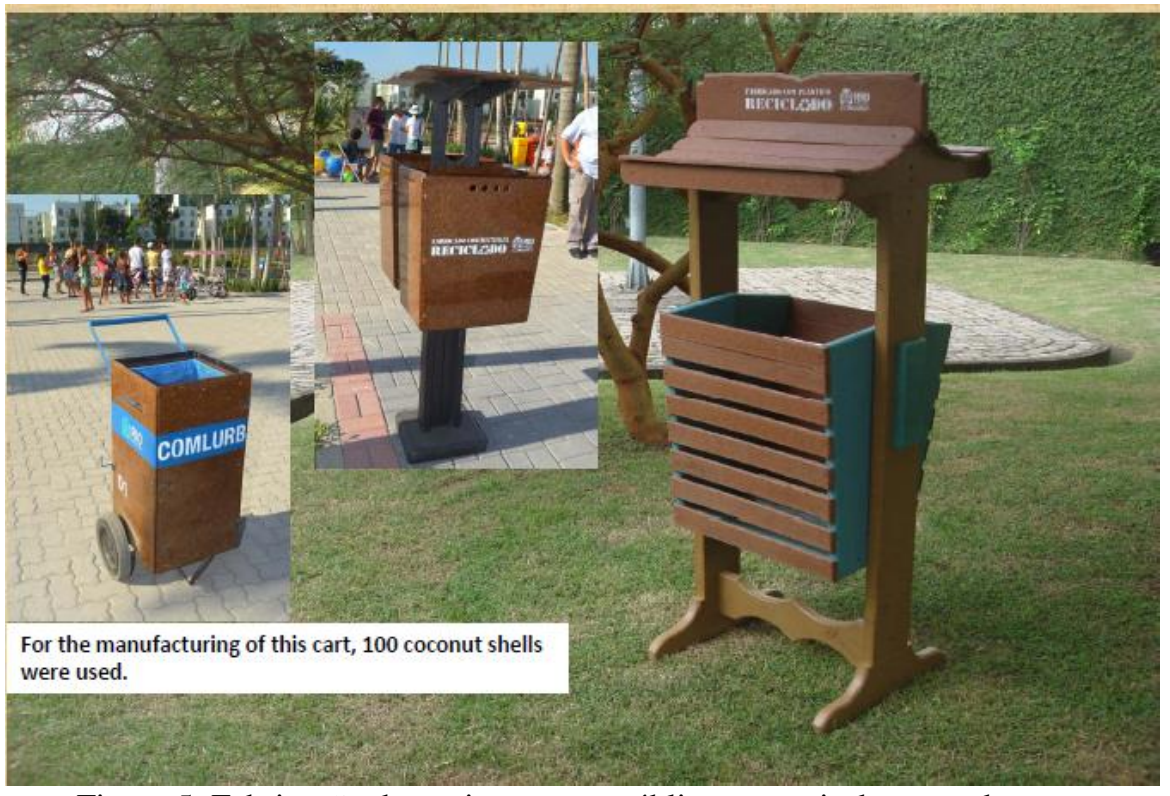

Figura 5: Fabricação de equipamentos públicos a partir da casca do coco Fonte: Comlurb 
Para alavancar as taxas de reciclagem na cidade do Rio de Janeiro, o incentivo fiscal presente no plano da cidade do Rio de Janeiro elaborado pela Câmara Técnica de Resíduos Sólidos do Conselho Municipal de Meio Ambiente (CONSEMA) é a isenção do Imposto Predial e Territorial Urbano (IPTU) para as empresas destinadas ao beneficiamento e reaproveitamento de materiais recicláveis provenientes do lixo gerado na cidade. Como o objetivo de desonerar a cadeia produtiva da reciclagem como também fomentar a implantação de indústrias no município do Rio de Janeiro.

A Secretaria Municipal de Obras, após o Decreto Municipal n 34.873/2011, que estabelece a "obrigatoriedade de utilização de misturas asfálticas contendo borracha de pneus inservíveis na pavimentação das vias expressas e rodovias no Município”, tem reaproveitado, mensalmente, 15.600 pneus inservíveis. Isto equivale a 78 toneladas de borracha que deixam de ser lançadas no meio ambiente (PMGIRS, 2012).

O sistema de logística reversa foi incluído na PNRS, como um instrumento de desenvolvimento ambiental, social e econômico com o objetivo de através de um conjunto de responsabilidades da cadeia de consumo viabilizar a coleta e o retorno de materiais recicláveis ou nocivos ao meio ambiente ao setor empresarial para fins de reaproveitamento ou disposição final adequada. Portanto, é um requisito dos PMGIRS, que as cidades destaquem quais geradores estarão incluídos no Sistema de Logística Reversa e como deverão proceder para efetuar a implementação do sistema. O Plano deve seguir as orientações determinadas nas resoluções do Conselho Nacional de Meio Ambiente (CONAMA) e dos Acordos Setoriais que ainda não foram totalmente concluídos pelo Governo Federal.

Apesar das orientações na esfera federal não estarem concluídas a época da finalização do PMGIRS do município do Rio de Janeiro, este poderia ter incluído as leis estaduais para alguns tipos de resíduos já que há resoluções que indicam o procedimento a ser seguido para determinados tipos de resíduo, como: os resíduos industriais tóxicos (Lei $\mathrm{n}^{\circ} 1.361 / 1988$ ), pilhas e baterias (Lei $\mathrm{n}^{\mathrm{o}}$ 3.183/1989), telefones e baterias celulares (Lei $n^{\circ} 2.939 / 1998$ ), embalagens de agrotóxicos (Lei no 3.972/2002), lâmpadas fluorescentes (Lei $n^{\circ}$ 5.131/2007), veículos em final de vida útil (Lei $\mathrm{n}^{\circ} 3.415 / 2000$ ), garrafas plásticas (Leis $\mathrm{n}^{\circ}$ 
3206/1999 e 3.369/2000) e óleos e gorduras de origem vegetal e animal (Lei ${ }^{\circ}$ $5.065 / 2007)$.

Portanto, o PMGIRS (2012) do Rio de Janeiro limitou-se a submeter que as ações do sistema de logística reversa estavam em andamento sob a responsabilidade do Governo Federal, tornando este item, de grande importância na PNRS, extremamente pendente de informações relevantes:

Dessa forma os órgãos da administração pública municipal aguardam a conclusão desses documentos para apoiarem as ações e passarem a exercer/executar sua parte de responsabilidade garantindo o fluxo dos resíduos reversos para os responsáveis por seu tratamento e destinação (PMGIRS, 2012, p.41).

Além disso, mesmo com os avanços na esfera federal na elaboração dos acordos setoriais, o Plano continua desatualizado já que sua atualização ocorre de quatro em quatro anos.

Em relação aos programas de educação ambiental, de acordo com o PMGIRS (2012), haverá um trabalho em conjunto com secretarias municipais de Meio Ambiente, Educação e de Conservação, além da Comlurb e outros órgãos municipais, para desenvolver programas e ações de educação ambiental voltadas para a não geração, a redução, a reutilização e a reciclagem de resíduos sólidos, podendo ser utilizados diferentes e importantes meios de divulgação (internet, TV, rádios, dentre outros) para atingir a conscientização da população. Os programas e ações de capacitação serão planejados e implementados de acordo com a legislação vigente e com o PMGIRS.

Durante a elaboração deste trabalho não foram constatados ações da Prefeitura promovendo a não geração, redução ou reutilização de materiais. Apenas a campanha Lixo Zero, analisada nas considerações finais, obteve divulgação.

O Plano Municipal de Gestão Integrada de Resíduos Sólidos será revisto pela Comlurb a cada quatro anos, conforme periodicidade prevista na PNRS, a partir da data de sua publicação, podendo ocorrer revisão em prazo inferior a este período caso a empresa identifique a necessidade de revisa-lo. 
Os recursos para a implementação do Plano podem ser de origem orçamentária, do Fundo de Conservação Ambiental (FCA), de acordos setoriais com o setor empresarial, nos termos do $\S 7$ o, do Art. 33 da PNRS, ou de parcerias com instituições públicas ou privadas, e quaisquer outras fontes de recursos destinadas a projetos de resíduos sólidos e de meio ambiente.

\section{7. Diretrizes da Política Municipal de Gestão Integrada de Resíduos Sólidos do Rio de Janeiro}

O Plano Municipal de Gerenciamento de Resíduos Sólidos - PMGIRS da Cidade do Rio de Janeiro tem como diretriz:

1. Garantir o cumprimento das medidas de controle estabelecidas quando do encerramento do Aterro Metropolitano de Jardim Gramacho, em Duque de Caxias, ocorrido em junho de 2012, mantendo-as, pelo período mínimo de 15 (quinze) anos, a exemplo do sistema de coleta e tratamento continuo ou venda do biogás, do sistema de tratamento do chorume coletado e do programa de monitoramento ambiental e geotécnico do maciço de resíduos dispostos; (PMGIRS, 2012, p. 42)

Segundo o PMGIRS (2012), o controle do sistema de chorume e monitoramento ambiental é realizado normalmente e nada foi encontrado na mídia que atualizasse a situação do aterro. De acordo com a Petrobras (2015), a venda do biogás é realizada à Reduc.

2. Garantir o encerramento do Aterro Remediado de Gericinó, em Bangu, mantendo em operação os sistemas ambientais existentes, a exemplo do estabelecido para o Aterro Metropolitano de Jardim Gramacho, e garantindo que a nova célula do Aterro de Gericinó, construída nos moldes de um aterro sanitário, seja destinada exclusivamente a situações de emergência ou a recepção de resíduos inertes; (PMGIRS, 2012, p. 42)

Realizado, o Aterro de Gericinó foi encerrado em abril de 2014.

3. Implantar projetos de Mecanismo de Desenvolvimento Limpo (MDL) onde aplicáveis, de modo a permitir a obtenção de recursos com a venda de créditos carbono, em consonância com o protocolo de Kyoto e seus sucedâneos, com ênfase na compostagem e recuperação e aproveitamento de gás de aterro, como nos casos do Centro de Compostagem, na Usina do Caju e do Aterro de Gericinó, em Bangu; (PMGIRS, 2012, p. 42) 
Segundo o Plano, 36\% dos ganhos com a venda dos créditos de carbono são revertidos, em partes iguais, a Comlurb e a Prefeitura de Duque de Caxias, que administrara sua parcela através de um fundo para recuperação do bairro de Jardim Gramacho. Nenhum outro projeto de MDL foi encontrado com a participação da Comlurb e a temática resíduos sólidos.

4. Garantir o cumprimento do Contrato no 10.2.2030.1/10, assinado entre o BNDES e o Município do Rio de Janeiro, para ampliação do Programa de Coleta Seletiva da Cidade do Rio de Janeiro, de acordo com as metas de coleta de materiais recicláveis previstas, contribuindo para a geração de trabalho e renda e garantindo a inclusão social de catadores em atividade em toda a cidade;

(PMGIRS, 2012, p. 42)

Das seis usinas de reciclagem planejadas, apenas uma delas (de Irajá) foi inaugurada até a conclusão deste trabalho.

5. Garantir o cumprimento do Programa de Coleta Seletiva Solidária em todos os prédios da Administração Pública Municipal, Escolas e Unidades de Serviços de Saúde; (PMGIRS, 2012, p. 42)

Sem informação na mídia ou documentos que comprovem a implementação do Programa. Com uma atualização do Plano mais frequente seria possivel um acompanhamento do cumprimento do Programa.

6. Garantir que os projetos de prédios públicos municipais reservem local adequado para armazenamento temporário de materiais recicláveis compatíveis com a geração prevista para os respectivos usos, de forma a facilitar os serviços de coleta seletiva da municipalidade; (PMGIRS, 2012, p. 42)

Sem informação na mídia ou documentos que comprovem a implementação do projeto. Com uma atualização do Plano mais frequente seria possivel um acompanhamento do cumprimento do projeto.

7. Apoiar a legalização, a organização e a capacitação das Associações e Cooperativas de Catadores de Materiais Recicláveis, em especial aquelas que participarem do Programa de Coleta Seletiva do município; (PMGIRS, 2012, p. 43)

Até a conclusão do trabalho, a profissão de catador não foi reconhecida pelo Minitério do Trabalho. Com o atraso das inaugurações das usinas de reciclagem, a organização e capacitação dos catadores ficou comprometida. 
8. Promover a inclusão no Sistema de Custos de Obras / SCO-Rio do Município, de itens provenientes das atividades e processos industriais de reciclagem de resíduos tais como agregados reciclados de RCC - Resíduos da Construção Civil, misturas asfálticas contendo borracha de pneus inservíveis, composto orgânico em obras de paisagismo e outros materiais decorrentes de novos processos e materiais aprovados, viabilizando assim o seu emprego nas obras públicas diretas; (PMGIRS, 2012, p. 43)

De acordo com o Plano, a Prefeitura tem reaproveitado, mensalmente, 15.600 pneus inservíveis. O composto orgânico foi utilizado para reflorestamento conforme figura 4.

9. Garantir a realização do Licenciamento Ambiental Simplificado das atividades beneficiadoras de materiais recicláveis nos termos da Resolução SMAC no 479/10, de forma a assegurar o fortalecimento da cadeia produtiva da reciclagem; (PMGIRS, 2012, p. 43)

Sem informação na mídia ou documentos que comprovem a realização do licenciamento. Com uma atualização do Plano mais frequente seria possivel um acompanhamento do cumprimento da atividade.

10. Promover o desenvolvimento, através de chamamentos públicos, de parcerias, convênios, protocolo de intenções com as mais diversas entidades, universidades, instituições de pesquisa, empresas, ONGs que se interessem e que possuam o devido credenciamento ambiental para o melhor aproveitamento dos diferentes tipos de resíduos sólidos (poda da arborização pública, RCC, etc.) com vistas a sustentabilidade ambiental e qualidade de vida da população; (PMGIRS, 2012, p. 43)

Sem informação na mídia ou documentos que comprovem a realização de chamamento público visando melhor aproveitamento dos diferentes tipos de resíduos sólidos. Com uma atualização do Plano mais frequente seria possivel um acompanhamento do cumprimento da atividade.

11. Incentivar a implantação de unidades de tratamento com recuperação energética e de compostagem descentralizadas, regionalizadas, com capacidade suficiente para absorver a maior parte dos resíduos orgânicos recolhidos pelo serviço municipal de coleta seletiva e ainda aqueles originários dos grandes centros comercializadores e consumidores de produtos orgânicos, como centrais de abastecimento, supermercados, hortifrútis, grandes hotéis; (PMGIRS, 2012, p. 43) 
Sem informação na mídia ou documentos que comprovem implantação. Com uma atualização do Plano mais frequente seria possivel um acompanhamento do cumprimento da atividade.

12. Fomentar a cadeia produtiva da reciclagem através da desoneração de tributos municipais aplicáveis, agilização do processo de licenciamento ambiental, utilização nas obras da administração pública municipal produtos provenientes da reciclagem de resíduos, dentre outras alternativas; (PMGIRS, 2012, p. 43)

Sem informação na mídia ou documentos que comprovem a desoneração de tributos municipais. Com uma atualização do Plano mais frequente seria possivel um acompanhamento do cumprimento da proposta.

13. Incentivar a adoção de alternativas para tratamento de resíduos que permitam o seu reaproveitamento, a redução de volume, minimizando a pratica de disposição em aterros convencionais; (PMGIRS, 2012, p. 44)

Sem informação na mídia ou documentos que comprovem práticas de reaproveitamento e redução de volume de resíduos sólidos. Com uma atualização do Plano mais frequente seria possivel um acompanhamento do cumprimento da proposta.

14. Incentivar ações de sensibilização visando os 3Rs, (reduzir, reutilizar e reciclar) as práticas sustentáveis, o consumo e a utilização sustentável dos recursos naturais e promover a proteção e a preservação do meio ambiente, em consonância com o desenvolvimento sustentável; (PMGIRS, 2012, p. 44)

Entrega de cartilhas em alguns domicílios no Município, com informações sobre produtos que podem ser reciclados e como proceder para que os resíduos sejam coletados .

15. Promover campanhas informativas e educativas sobre a produção e manuseio de resíduos sólidos e sobre os impactos negativos que os resíduos sólidos causam ao meio ambiente, a saúde e a economia; (PMGIRS, 2012, p. 44)

Campanha do Lixo Zero, multando o cidadão que descartar o resíduo, qualquer que seja ele, em lugar público inadequado. 
16. Promover, em consonância com o PMGIRS e em articulação com as Secretarias de Educação, de Meio Ambiente e de Conservação, a Comlurb e demais órgãos municipais, programas e ações de educação ambiental voltadas para a não geração, a redução, a reutilização e a reciclagem de resíduos sólidos, podendo ser utilizados diferentes meios para a divulgação e conscientização (internet, TV, rádios, dentre outros); (PMGIRS, 2012, p. 44)

Sem informação na mídia ou documentos que comprovem este tipo de ações. Com uma atualização do Plano mais frequente seria possivel um acompanhamento do cumprimento da proposta.

17. Garantir o diálogo metropolitano com os diferentes atores: órgãos estaduais e municipais, entidades de classe, sociedade civil organizada, ONGs, cooperativas de catadores e catadores independentes; (PMGIRS, 2012, p. 45)

Não está especificado no Plano quais estratégias utilizadas para garantir o diálogo entre os diferentes atores.

18. Garantir o cumprimento, em conjunto com os demais órgãos da administração municipal, do estabelecido neste Plano Municipal de Gestão Integrada de Resíduos Sólidos - PMGIRS, mantendo sua atualização conforme programação prevista; (PMGIRS, 2012, p. 45)

Algumas ações até o momento não foram implementadas e algumas metas para 2013 não foram atingidas, como, por exemplo, a percentagem de materiais reciclados. Porém, a atualização do Plano só ocorrerá em 2016.

19. Garantir a implementação e operacionalização do presente Plano Municipal de Gestão Integrada de Resíduos Sólidos - PMGIRS, cabendo como ação inicial de capacitação a divulgação contextualizada do referido Plano junto a gestores municipais e atores relevantes, tais como os setores econômicos afetados pela logística reversa, entre outros. (PMGIRS, 2012, p. 45)

Sem informação na mídia ou documentos que comprovem este tipo de ações. Com uma atualização do Plano mais frequente seria possivel um acompanhamento do cumprimento da implementação e operacionalização. 


\section{8.}

\section{Metas até final dos anos de 2013, 2016 e 2020}

\begin{tabular}{|c|c|c|c|}
\hline METAS A SEREM ALCANÇADAS & Até final de 2013 & $\begin{array}{l}\text { Até final de } \\
2016\end{array}$ & Até final de 2020 \\
\hline $\begin{array}{l}\text { Desenvolver e implantar projetos de } \\
\text { disposição final, ambientalmente } \\
\text { sustentáveis, visando atingir o Índice da } \\
\text { Qualidade de Aterros de Resíduos - } \\
\text { IQR, maior ou igual a } 8,1, \\
\text { correspondente a condições adequadas } \\
\text { até } 2013 \text {, conforme consta no Plano } \\
\text { Plurianual } 2010 \text { - } 2013 \text { da PCRJ, } \\
\text { adotando medidas preventivas e } \\
\text { corretivas para garantir a manutenção do } \\
\text { índice acima do estabelecido. }\end{array}$ & $\begin{array}{c}100 \% \text { dos } \\
\text { resíduos sólidos } \\
\text { de competência } \\
\text { municipal } \\
\text { encaminhados ao } \\
\text { CTR-Rio, em } \\
\text { Seropédica, } \\
\text { garantido o IQR } \\
\text { de seu aterro } \\
\text { sanitário maior ou } \\
\text { igual a } 8,1 \text { ou } \\
\text { outra disposição } \\
\text { equivalente }\end{array}$ & $\begin{array}{c}100 \% \text { dos } \\
\text { resíduos sólidos } \\
\text { de competência } \\
\text { municipal } \\
\text { encaminhados ao } \\
\text { CTR-Rio, em } \\
\text { Seropédica, } \\
\text { garantido o IQR } \\
\text { de seu aterro } \\
\text { sanitário maior } \\
\text { ou igual a } 8,1 \text { ou } \\
\text { outra disposição } \\
\text { equivalente }\end{array}$ & $\begin{array}{l}100 \% \text { dos } \\
\text { resíduos sólidos } \\
\text { de competência } \\
\text { municipal } \\
\text { encaminhados ao } \\
\text { CTR-Rio, em } \\
\text { Seropédica, } \\
\text { garantido o IQR } \\
\text { de seu aterro } \\
\text { sanitário maior } \\
\text { ou igual a } 8,1 \text { ou } \\
\text { outra disposição } \\
\text { equivalente }\end{array}$ \\
\hline $\begin{array}{l}\text { Garantir que os resíduos gerados nas } \\
\text { atividades de poda da arborização } \\
\text { municipal tenham destinação } \\
\text { ambientalmente adequada, com ênfase } \\
\text { na compostagem e no seu } \\
\text { aproveitamento energético, desde que } \\
\text { identificada alternativa técnica ou } \\
\text { ambientalmente viável } \\
\end{array}$ & - & $\begin{array}{l}50 \% \text { dos } \\
\text { resíduos gerados }\end{array}$ & $\begin{array}{l}100 \% \text { dos } \\
\text { resíduos gerados }\end{array}$ \\
\hline $\begin{array}{l}\text { Realizar o mapeamento das áreas } \\
\text { degradadas pela disposição irregular de } \\
\text { resíduos sólidos urbanos, resíduos da } \\
\text { construção civil - RCC, entre outros, } \\
\text { providenciando o encerramento do } \\
\text { vazamento irregular e responsabilizando } \\
\text { o autor da degradação para recuperação } \\
\text { da área }\end{array}$ & - & $\begin{array}{l}\text { Realizar o } \\
\text { mapeamento das } \\
\text { áreas degradadas } \\
\text { da Cidade }\end{array}$ & $\begin{array}{l}\text { Promover a } \\
\text { recuperação/reme } \\
\text { diação das áreas } \\
\text { mapeadas }\end{array}$ \\
\hline $\begin{array}{l}\text { Garantir que a frota terceirizada de } \\
\text { veículos de limpeza urbana da Cidade } \\
\text { operem com combustíveis renováveis ou } \\
\text { híbridos, desde que identificada } \\
\text { alternativa técnica, econômica e } \\
\text { ambientalmente viável }\end{array}$ & $\begin{array}{l}10 \% \text { da frota } \\
\text { terceirizada }\end{array}$ & $\begin{array}{l}70 \% \text { da frota } \\
\text { terceirizada }\end{array}$ & $\begin{array}{l}100 \% \text { da frota } \\
\text { terceirizada }\end{array}$ \\
\hline $\begin{array}{l}\text { Coleta Seletiva da fração orgânica e } \\
\text { respectivo tratamento, desde que } \\
\text { identificada alternativa técnica, } \\
\text { econômica e ambientalmente viável }\end{array}$ & - & $\begin{array}{l}10 \text { \% da fração } \\
\text { orgânica }\end{array}$ & $\begin{array}{c}100 \% \text { da fração } \\
\text { orgânica }\end{array}$ \\
\hline $\begin{array}{c}\text { Coletar os materiais recicláveis da } \\
\text { Cidade, conforme consta no Plano } \\
\text { Plurianual } 2013 \text { - } 2016 \text { da PCRJ, com } \\
\text { ênfase na identificação de alternativa } \\
\text { técnica, econômica e ambientalmente } \\
\text { viável }\end{array}$ & $\begin{array}{l}5 \% \text { dos materiais } \\
\text { recicláveis de } \\
\text { origem domiciliar }\end{array}$ & $\begin{array}{l}25 \% \text { dos } \\
\text { materiais } \\
\text { recicláveis de } \\
\text { toda a Cidade, } \\
\text { incluindo as } \\
\text { atividades } \\
\text { públicas e } \\
\text { privadas }\end{array}$ & - \\
\hline
\end{tabular}




\section{5. \\ Considerações Finais}

A relação de produtos consumidos e descartados diariamente é gigantesca e, com isso, os recursos naturais se tornam cada vez mais escassos. A matéria prima é extraída da natureza, processada, manufaturada e depois comercializada como bem de consumo para satisfazer as necessidades e desejos dos milhares de consumidores do Brasil.

As Prefeituras responsáveis pelo manejo do RSU encontram grandes dificuldades já que as áreas próximas aos centros urbanos, destinadas a abrigar os dejetos, ou seja, transformarem-se em aterros sanitários, são cada vez mais raras tornando complexo e problemático o desafio de encontrar uma região apta a receber os resíduos. Ainda há a rejeição da população em residir ou trabalhar próximo a um aterro sanitário ou ETR, característica encontrada nas duas metrópoles pesquisadas, devido a grande circulação de carretas, a poluição sonora e o odor.

A Política Nacional de Resíduos Sólidos determinava a extinção dos lixões até 02 de Agosto de 2014 em todos os municípios do Brasil. Dias após a publicação do marco regulatório, foram divulgados relatórios da ABRELPE com números desafiadores para as Prefeituras, já que de acordo com eles, existiam aproximadamente 3.500 lixões ativos em todas as regiões brasileiras. Essa não foi a primeira tentativa frustrada para atingir a meta de erradicação dos lixões.

Importante ressaltar que a exigência da implementação do PMGIRS (Plano Municipal de Gestão Integrada de Resíduos Sólidos), é uma condição para o município ter acesso a recursos federais, por meio de incentivos e financiamentos, traduzindo a política de coerção para a observância legal. No caso do Rio de Janeiro, existe também a Lei Municipal $n^{\circ}$ 5.248/2011, que estabelece em seu artigo $6^{\circ}$, metas de redução de emissões antrópicas de GEE para o Município do Rio de Janeiro até o ano de 2016, período de tempo que abrange o Plano. A eliminação de resíduos por meio de queimadas é um forte emissor de gás metano (CH4) que apresenta potencial de aquecimento global 21 vezes maior que o gás 
dióxido de carbono (CO2), razão pela qual o PMGIRS deve considerar a necessidade da redução desses gases.

Nas análises do PMGIRS do Rio de Janeiro e as ações da Prefeitura mostram que a temática ainda é abordada de forma conservadora, com bastante foco no descarte dos resíduos, em dissonância com a PNRS, que tem como objetivo ações que priorizem a redução na geração de resíduos. O percentual de materiais reciclados na cidade do Rio de Janeiro ainda é baixo apesar do sistema de coleta seletiva, cada vez mais, abranger uma maior cobertura da cidade.

O PMGIRS do Rio de Janeiro tem como orientação o conteúdo mínimo da PNRS, porém o documento ainda assim apresenta muitos pontos de forma superficial sem o devido detalhamento das estratégias para lidar com os atuais problemas e antecipar possíveis desafios do futuro. A PNRS é bastante clara e contundente quanto à importância da não geração e redução dos resíduos, porém o Plano do município do Rio de Janeiro não contempla ações focando nesta orientação. Apesar de apresentarem alguns de seus objetivos e metas de acordo com a PNRS, a falta de detalhes no PMGIRS de como planejam atingir esses resultados, ou seja, ações, iniciativas e estratégias para cada uma das metas, não são explícitadas. Outro ponto que enaltece o descompromisso público é a falta de atualização do plano que é revisto apenas de quatro em quatro anos apresentando assim ações descontinuadas e projetos que supostamente estariam lançados de acordo com o Plano, mas não saíram do papel. Algumas medidas e campanhas foram implementadas, porém não tiveram suas ações divulgadas. Portanto, o documento é incompleto e com deficiências que evidenciam ser a razão para que a esfera federal não tenha reconhecido ainda o PMGIRS do Rio de Janeiro. O Plano Municipal de Nova Iorque é revisto e atualizado anualmente, assim o andamento das ações e metas da cidade tem melhor acompanhamento evitando a defasagem das propostas.

O programa Lixo Zero lançado em agosto de 2013 pela Prefeitura do Rio de Janeiro prevê a aplicação de multas entre $\mathrm{R} \$ 170,00$ a $\mathrm{R} \$ 1.062,00$ para quem sujar a cidade. $\mathrm{O}$ valor da multa é aplicado de acordo com o tamanho do material (até $1 \mathrm{~m}^{3}$, superior a $1 \mathrm{~m}^{3}$ ou até grandes quantidades de resíduos formando depósitos irregulares). A iniciativa tem como objetivo tornar a Lei de Limpeza 
Urbana $n^{\circ}$ 3273/2001 efetiva, além de conscientizar a população da importância de não jogar lixo em áreas públicas, melhorando a qualidade da limpeza da cidade.

A expressão "Lixo Zero" ganhou outra conotação no Rio de Janeiro, pois na visão de outras cidades no mundo, lixo zero se refere ao não envio de resíduos aos aterros sanitários ou plantas incineradoras. Podemos observar que no caso do Rio de Janeiro, apesar de ter como objetivo a conscientização, a iniciativa tem um caráter punitivo, pois há aplicação de multas, mas sem a preocupação de educar o cidadão quanto à problemática do RSU, limitando-se a destinação dos resíduos às lixeiras. Não há uma diferenciação em relação aos resíduos que estão sendo descartados, se é um material tóxico, reciclável, orgânico, tampouco um incentivo a não geração destes resíduos. É uma iniciativa que apesar de evitar a poluição e contribuir para a melhoria da saúde pública poderia ser mais eficiente se os conceitos da PNEA fossem abordados. Um enfoque realístico tratando a temática de uma forma ampla mostrando os reais problemas da geração e disposição incorreta dos resíduos. De acordo com a Comlurb (2015), há a mobilização de mais de 600 profissionais para a fiscalização e parcerias com as empresas de mobilidade urbana da cidade para a divulgação da campanha. Porém, a campanha não prevê nenhum incentivo para um das questões centrais da PNRS, a não geração ou redução de RSU.

De acordo com Vinícius Roriz, presidente da Comlurb, em entrevista a Agencia Brasil:

a coleta de lixo domiciliar hoje é bem mais barata que o processo de varrição e coleta de resíduos nas vias púbicas. O cidadão paga mais caro em função do descarte de lixo na rua de forma inadequada. Se tirarmos esse fator, vai haver um impacto importante, que irá nos permitir redimensionar nossas equipes, que chegarão a lugares onde a cobertura não é boa (EXAME, 2013).

De acordo com os dados do Sistema Nacional de Informações sobre Saneamento (SNIS) em 2013 foram gastos pela Prefeitura do Rio de Janeiro $\mathrm{R} \$ 217,00$ reais por tonelada com a varrição de logradouros públicos e $\mathrm{R} \$ 150,00$ reais por tonelada com a coleta de resíduos domiciliares e públicos, ou seja, a varrição custa $44,5 \%$ a mais que a coleta para os cofres da Prefeitura por tonelada. Portanto, não é incorreto identificar e apontar que o descarte inadequado 
sobrecarrega o orçamento. Medidas coercitivas econômicas, como aplicação de multas, podem apresentar bons resultados caso haja fiscalização e, neste caso, a instalação e manutenção de lixeiras distribuídas adequadamente pela cidade para serem dispensados os resíduos. Porém, a utilização de uma abordagem educativa focando na conscientização da não geração de resíduos, poderia não só possibilitar uma menor despesa com a varrição, mas também com a coleta, já que haveria menos resíduos a serem transportados e aterrados. A partir dos estudos realizados para essa dissertação, a tendência dos órgãos responsáveis pela gestão de RSU na Europa e nos EUA é exatamente reduzir na fonte a quantidade de resíduo gerado a fim de diminuir o custo total de manejo do resíduos.

As usinas de reciclagem e compostagem geram emprego e renda. De acordo com Bastos,

o índice de reciclagem mecânica de plásticos (transformação dos resíduos plásticos em grânulos para a fabricação de novos produtos) no Brasil é de 16,5\%, sendo superado apenas pela Alemanha $(31,1 \%)$ e pela Áustria $(19,1 \%)$. A informação é da Plastivida Instituto Sócio-Ambiental dos Plásticos após estudo nacional inédito elaborado pela Maxiquim no ano passado, com base nos resultados de 2003, e metodologia do Instituto Brasileiro de Geografia e Estatística/IBGE. A pesquisa mostra que a indústria da reciclagem de plásticos no Brasil é formada por cerca de 490 empresas recicladoras, $80 \%$ delas concentradas na região Sudeste. Juntas, elas faturam cerca de R $\$ 1,22$ bilhão e geram 11.500 empregos diretos. Têm capacidade instalada para reciclar 1,05 milhão de toneladas por ano, consomem 777 mil toneladas e produzem $703 \mathrm{mil}$ toneladas de plásticos reciclados (BASTOS, 2014, p.137).

Além de contribuírem com as questões econômicas e sociais, a reciclagem e a compostagem apresentam vantagens ambientais já que favorecem na redução da quantidade de resíduos que serão dispostos no solo, em aterros sanitários. A economia da energia gasta na transformação da matéria-prima, já contida no reciclado é mais um ponto positivo da reciclagem. De acordo com o CEMPRE, a cada quilo de alumínio reciclado, cinco quilos de bauxita são deixados de ser extraídos do meio ambiente. Além desse benefício a reciclagem proporciona uma economia de $95 \%$ de energia elétrica.

A formação do composto orgânico adequado para nutrir o solo destinado à agricultura, corrigir uma eventual acidez do solo e ao reflorestamento são 
importantes contribuições das usinas de compostagem. O húmus ${ }^{29}$ torna o solo poroso, permitindo a aeração das raízes, retenção de água e dos nutrientes (MONTEIRO, 2001).

De acordo com a caracterização gravimétrica da Prefeitura do Rio de Janeiro, a quantidade de matéria orgânica supera o total de materiais potenciais a reciclagem. Portanto, é indicado que soluções para o reaproveitamento da matéria orgânica sejam consideradas, já que o composto pode ser reaproveitado como fertilizante e contribuir para a mitigação dos GEE. Como destacado no PMGIRS, a Comlurb já produz na Usina do Caju composto orgânico na ordem de 15 mil metros cúbicos por ano. Esta quantidade poderia ser ainda maior com a utilização de novas tecnologias e a ampliação do uso do produto para que seja economicamente viável a sua produção.

O atraso nas obras de construção das usinas de reciclagem no município é um ponto bastante negativo neste contexto dificultando o aumento da porcentagem de materiais reciclados. Apesar do acordo com o BNDES ter sido firmado no final de 2010, apenas a CTR de Irajá, com 18 meses de atraso, foi inaugurada. Também não foram encontradas durante a elaboração da dissertação as ações mencionadas no PMGIRS de divulgação de conscientização da população quanto ao processo de coleta seletiva.

A coleta seletiva iniciou oficialmente na cidade do Rio de Janeiro em fevereiro de 2002, em um projeto-piloto nos bairros da Zona Sul do município da cidade, como objetivo de cumprir as exigências da Lei Municipal de Limpeza Urbana $\mathrm{n}^{\circ}$ 3.273, de 06 de setembro de 2001. De acordo com a Comlurb, é possível perceber um aumento gradativo no número de localidades atendidas, em janeiro de 2015, eram 67 dos 160 bairros da cidade. Caminhões compactadores são utilizados e a Prefeitura da cidade ressalta que este modelo não prejudica o seu aproveitamento para a reciclagem. De acordo com o SNIS, a taxa de cobertura da coleta seletiva em relação à população urbana cresceu 76,01\% entre os anos de 2012 e 2013. No relatório do SNIS não há informação quanto aos anos anteriores a 2012.

\footnotetext{
${ }^{29}$ Húmus é a matéria orgânica que resulta da decomposição de animais e plantas mortas.
} 


\section{Cobertura Coleta Seletiva no Rio de \\ Janeiro (\%)}

2012

29,70

2013

Taxa de cobertura da col. Seletiva porta-a-porta em relação a pop. Urbana

Tabela 9: Cobertura da Coleta Seletiva no Rio de Janeiro Fonte: SNIS, 2013.

Apesar de mais da metade da população ser atendida pela coleta seletiva na cidade do Rio de Janeiro, a quantidade de materiais reciclados ainda é extremamente baixa, menos de $1 \%$ em relação a quantidade de RDO e RPU em 2013, conforme apresentado no gráfico baixo.

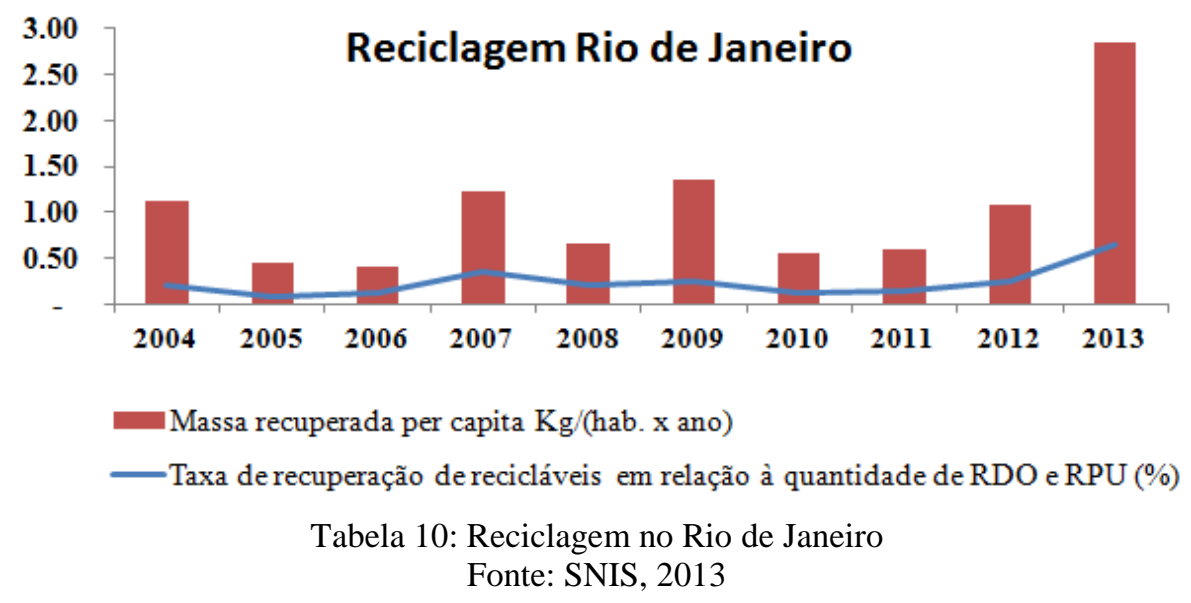

Este percentual de reciclagem está abaixo da meta estabelecida pelo Plano, conforme mostrado na tabela 8 .

Já na cidade de Nova Iorque a taxa de recuperação de materiais recicláveis ficou em 15\%. Para resíduos domiciliares a taxa de reciclagem atingiu 27\% (PLANYC, 2011)

Monteiro (2001), destaca que de acordo com especialistas, a indústria de produtos reciclados só terá êxito quando houver um forte investimento e subsídio do Governo, o exemplo nos é dado pelos países da Europa que investem milhões de euros nesta técnica. Para Bastos (2014), a situação das cooperativas do Rio de 
Janeiro é bastante complexa, pois, apesar da Comlurb ter projetos de ampliação das unidades de reciclagem e aumentar gradativamente a cobertura da coleta seletiva no município do Rio de Janeiro, estas iniciativas não se reverteram em lucro para as cooperativas, uma vez que antes de chegar nas Usinas de Reciclagem o material potencial à reciclagem é recolhido por catadores de rua e/ou atravessadores, chegando nas unidades apenas parte do material separado nos domicílios. Portanto, a quantidade de materiais reciclados não cobrem os custos operacionais do sistema já que é necessário escala para tornar essa técnica economicamente viável. Essa inconsistência no planejamento da coleta, afirma Bastos (2014), foi o motivador para a desativação da unidade de Botafogo em 2006.

É necessário que as três esferas do governo incentivem o processo de reciclagem através de investimentos. Campanhas educativas mostrando os benefícios da reciclagem, como proceder para reciclar um material e fiscalizar para inibir a ação de atravessadores são algumas ações necessárias para alavancar a técnica de reaproveitamento dos resíduos. Além disso, no âmbito econômico é preciso diminuir a taxação por produtos reciclados para motivar as indústrias a comprarem este tipo de produto. Não há diferenciação no imposto arrecado como, por exemplo, IPI (Imposto sobre Produto Industrializado) ou ICMS (Imposto sobre Circulação de Mercadorias e Serviços), e o produto acaba sendo taxado mais de uma vez, já que foi taxado na sua fabricação e após ser reciclado.

Outra alternativa encontrada para alavancar as taxas de reciclagem é a instalação de contêineres direcionados a coleta seletiva ampliando os pontos de descarte e os postos de entrega voluntários em vias e logradouros públicos. $\mathrm{Na}$ cidade do Rio de Janeiro não há coleta seletiva para resíduo público, e este tipo de resíduo representa 34\% (SNIS,2013), ou seja, uma parcela importante do total coletado no município. A viabilidade para instalação desses equipamentos pode ser operacionalizada ainda através de parcerias com empresas privadas que podem, por exemplo, financiar a colocação dos contêineres e em contrapartida explorar o espaço publicitário. Importante ressaltar que os equipamentos instalados sejam protegidos de furtos para que atravessadores ou catadores de rua não utilizem este recurso como fonte de renda. A prefeitura de Nova Iorque 
instalou estrategicamente nas vias públicas da cidade receptores de coleta seletiva com o objetivo de alavancar a taxa de produtos reciclados pois a capacidade de reciclagem aumentou depois da inauguração da marina localizada no sul do Brooklyn capaz de seperar opticamente plástico, metal e vidro.

Os resíduos que não forem reutilizados, reciclados ou compostados são encaminhados para o aterro sanitário. Com o fechamento do aterro sanitário controlado de Gramacho, a Prefeitura teve que selecionar uma área para receber diariamente cerca de 9 mil toneladas de resíduos por dia (SNIS, 2013).

O local escolhido para a instalação do aterro dos RSU da cidade do Rio de Janeiro, "CTR Seropédica", no município vizinho de Seropédica, sofreu resistência da população local, principalmente da Universidade Federal Rural do Rio de Janeiro. Destaca Pimenteira (2010), professor da Instituição, que a administração pública não escolheu corretamente o local, pois a área está sobre uma reserva natural estratégica de água para o Estado do Rio de Janeiro, o aquífero Piranema. A grande preocupação da população é que em caso de acidente no sistema de drenagem do chorume, seria grande o risco de contaminação do reservatório natural de água no subsolo da região.

Ainda segundo Pimenteira (2010), mesmo com a instalação dos eletrodos capazes de detectar o vazamento, até a completa remediação do local, a reserva de água teria grandes chances de ser impactada.

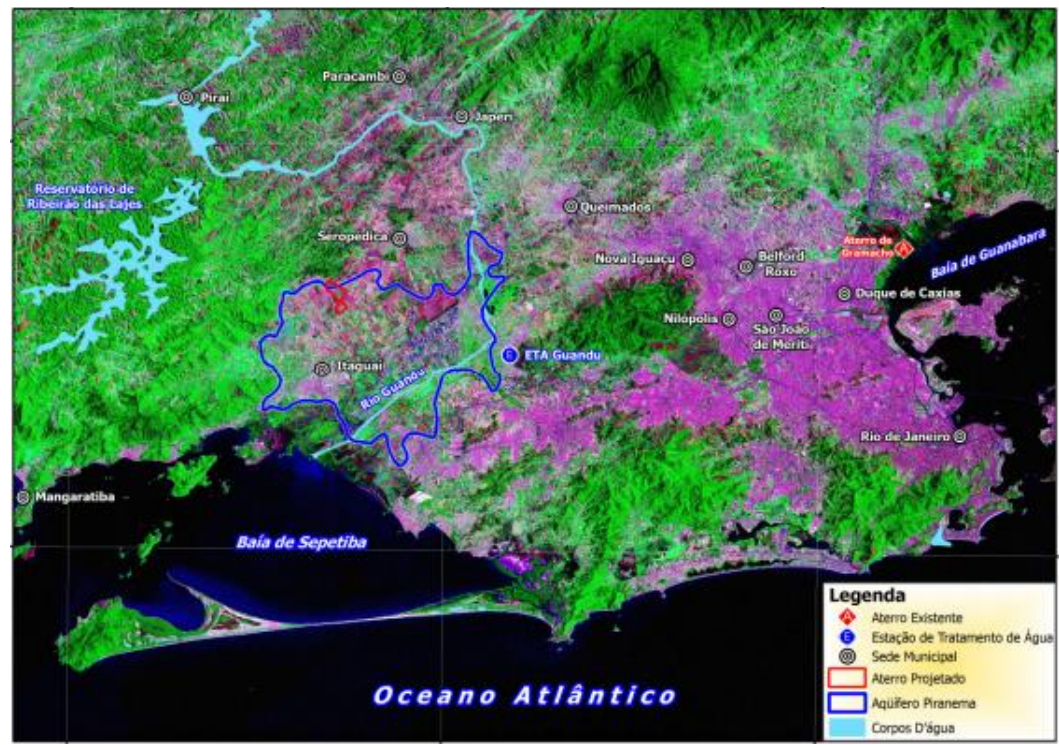

Figura 6: Localização do aterro de Seropédica Fonte: Pimenteira 
Segundo o "Inventário e cenário de emissões de gases do efeito estufa da Cidade do Rio de Janeiro: resumo técnico", publicado pelo "Coleção Estudos Cariocas" (RIO DE JANEIRO, 2011), o meio de transporte rodoviário é responsável por $33 \%$ das emissões de poluentes na cidade, em seguida, são os lançamentos de gases provenientes do lixo que representam $25 \%$ das emissões. Portanto, a temática transporte rodoviário e gestão dos RSU são de fundamentais importância para atingir a meta da Prefeitura de redução na emissão de GEE para 2016 e 2020. Uma alternativa adotada na cidade de Nova Iorque para mitigar a emissão de GEE, além de melhorar o trânsito da cidade e reduzir a poluição sonora, é a substituição das carretas por trens e barcas. Isto porque o resíduo gerado na cidade de Nova Iorque, assim como no Rio de Janeiro, também é exportado, ou seja, transportados por grandes distâncias até outras cidades onde se encontram os seus respectivos aterros sanitários. $\mathrm{O}$ aterro de Seropédica encontra-se próximo da linha férrea (ramal Japerí) e o Porto de Sepetiba e poderiam ser alternativas à cidade do Rio de Janeiro como meio de transporte dos resíduos gerados no município, contribuindo para diminuir a quantidade de viagens (cerca de $120 \mathrm{~km}$ ida e volta) das carretas entre as ETR e o aterro de Seropédica.

Outra semelhança entre as cidades estudadas foi a desativação recente dos seus respectivos aterros controlados. Em Nova Iorque, Fresh Kill, foi desativado em 2001 e no Rio de Janeiro, o Aterro Metropolitano do Jardim de Gramacho, onze anos depois. Reconhecidos mundialmente pela quantidade de resíduos que recebiam, cerca de trinta mil e nove mil toneladas por dia respectivamente, suas operações e desativações foram um marco para ambas as cidades. Os custos de descarte nesses locais eram o grande atrativo para as duas prefeituras municipais apesar da forte pressão de ambientalistas e sociedade para seu fechamento por causa dos danos ambientais e sociais causados nas suas respectivas regiões. Um fator que chama a atenção e deverá ser analisado pela Comissão de Inquérito Parlamentar aberta em março de 2015, é que apesar do preço cobrado pela tonelada de resíduo dispensada no no aterro sanitário de Seropédica ser pelo menos oito vezes maior que em Gramacho, no quadro de despesas da Comlurb apresentado pelo SNIS (2013) não há uma diferença significativa em relação a 
2012, data do fechamento de Gramacho, como apresentado no caso da cidade de Nova Iorque, quando Fresh Kills foi desativado.

O desconhecimento dos resíduos comerciais é um desafio para ambas as cidades. Como é responsabilidade do comércio contratar a empresa responsável pela coleta, transporte e disposição final, em ambas as cidades as prefeituras não têm qualquer controle de otimização das rotas e da caracterização gravimétrica desses resíduos coletados. Portanto, o congestionamento de caminhões de diferentes empresas executando a mesma rota e os custos de oportunidade dos materiais passíveis de serem reciclados geram um passivo. O Plano de Nova Iorque cita a condução de um estudo a fim de otimizar a gestão dos resíduos comerciais. Conforme abordado no capítulo referente as contribuições da PNRS, há necessidade da criação permanente de um Sistema de Informações sobre a Gestão dos Resíduos Sólidos, e infraestrutura para receber, classificar, consolidar os dados referentes a gestão de resíduos RSU com o objetivo de apoiar organizações no processo decisório. O Plano Municipal do Rio de Janeiro não comenta como pretende abordar essa questão.

De acordo com o PLANYC, na cidade ocorrem eventos patrocinados pela Prefeitura para a realização de doações de objetos e descarte de materiais com componentes tóxicos, os quais precisam de um manuseio adequado. Essas ações poderiam ser implementadas, com baixo custo operacional na cidade do Rio de Janeiro. Uma ferramenta importante para a destinação correta desses materiais que possuem em sua composição elementos de alto valor para o mercado consumidor, como chumbo e cobre. Além dos benefícios ambientais, a doação de objetos seria uma melhoria social beneficiando as classes menos favorecidas a adquirir produtos que seriam descartados.

Apesar das inúmeras iniciativas na cidade de Nova Iorque, Garmerman, Brecher e Dardia (2015) ressaltam que gerenciamento de resíduos sólidos da cidade precisa de uma reforma. O custo para a cidade coletar o resíduo é o dobro do setor privado e a disposição final em aterros distantes da cidade geram um alto custo fiscal e ambiental. Em 2012, Nova Iorque gastou 1,5 bilhão de dólares com gerenciamento de resíduo sólido na cidade. Segundo os autores, a população da cidade americana não tem conhecimento do aumento dos custos com o manejo do 
RSU. Eles também sugerem que a primeira mudança seja a adoção da estratégia de cobrar os residentes por volume de resíduo gerado. Atualmente, é pago um valor fixo por residência assim como é realizado na cidade do Rio de Janeiro. As pesquisas dos autores mostram que nas cidades americanas onde este modelo foi implementado, a taxa de desvio dos resíduos é superior a cidade de Nova Iorque. Isto porque os residentes passam a ter consciência dos custos no manejo do resíduo já que passam a pagar um valor variável de acordo com o volume gerado. Os autores ressaltam que em paralelo a essa cobrança por volume sejam implementadas ações educativas evitando a geração de resíduos.

A partir desta análise, foi possível concluir, com maior clareza, que há um longo caminho a ser percorrido para a redução do RSU na cidade do Rio de Janeiro. A PNRS é uma importante ferramenta para integrar a sociedade e responsabilizar cada parte pelos resíduos gerados. Além disso, a lei está baseada em pilares, ou seja, ações que foquem na não geração, redução, reutilização, reciclagem e compostagem dos materiais a fim de diminuir a quantidade de resíduos gerados diariamente pela população e posteriormente encaminhados aos aterros sanitários. Apesar da atual sociedade do descarte, existe um movimento, ainda não estabelecido no Rio de Janeiro, de não geração de resíduos.

A participação do poder público com ações de incentivos fiscais na redução e reciclagem de resíduos, transparências nas contas de manejo, forte trabalho de conscientização da população sobre os malefícios da geração de resíduos e a realização de eventos para doação e restauração de produtos em desuso, são essenciais por parte do Governo. Apesar da meta da cidade em diminuir os GEE já em 2016, há poucos ações voltadas para este objetivo. No cenário atual do município do Rio de Janeiro, as emissões de gases poluentes provenientes dos resíduos são a segunda maior causa de contaminação do ar, perdendo apenas para o transporte rodoviário (RIO DE JANEIRO, 2011). No lado técnico, é preciso que o PMGIRS do Rio de Janeiro seja revisto e aperfeiçoado para atender as necessidades da PNRS a fim de ser aprovado guiando as políticas sustentáveis da cidade.

Em relação ao setor privado, nota-se uma tendência na economia colaborativa, onde o compartilhamento de produtos é a alternativa encontrada para 
otimizar as necessidades dos consumidores, consequentemente reduzindo a quantidade de resíduos gerados. É possível notar também a fabricação de produtos, ou até mesmo o retorno de alguns deles, que são reutilizáveis e substituem os não ambientalmente sustentáveis, fazendo com que, é óbvio, se polua menos. O uso da tecnologia, como a internet e aplicativos, é uma das ferramentas chave para a implementação de algum destes produtos. Como, por exemplo, a garrafa de plástico dobrável que junto com o aplicativo de celular mostra a presença de bebedouros na cidade de Londres, reduzindo assim a necessidade de comprar água em garrafas Pet (OHYO, 2015). A criação de sites na internet que compartilham produtos que raramente são usados mas necessários como: furadeira elétrica, barraca de camping entre outros.

De acordo com o estudo de Garmerman, Brecher e Dardia (2015), realizado nas maiores cidades americanas, uma das maneiras mais efetivas para a redução na geração de resíduos sólidos urbano é o modelo de cobrança proporcional ao volume gerado, ou seja, existe uma diferença para mais ou para menos no custo da quantidade de resíduos gerados, determinando, sobremaneira, uma conscientização por parte da população na redução da geração de resíduos. Portanto, o nosso trabalho sugere que seja realizado um estudo de viabilidade econômica e operacional para a aplicação deste modelo na cidade do Rio de Janeiro para as unidades residenciais. A cobrança proporcional tem se mostrado bastante efetiva, não só nos Estados Unidos, mas também em cidades da Europa por diminuírem a taxa de resíduos encaminhados para as plantas de disposição final. Cabe ressaltar que no Rio de Janeiro, os resíduos comerciais coletados pelas empresas privadas já são cobrados de acordo com o volume gerado.

Observamos ao longo dessa dissertação uma crescente preocupação com a quantidade e qualidade da redução de resíduos. Mas insistimos em focar o nosso olhar na premissa da redução da geração dos resíduos sólidos, pois esta é uma necessidade que deve ser acompanhada de regulamentação, mecanismos de cobrança, e, sobretudo, nosso comportamento frente à esta questão que começa e termina com nossos gestos e atitudes de consumo. 
Esta dissertação chega ao fim e visa ter contribuído à comunidade acadêmica no sentido de levantar questões e apresentar dados que servirão para o aprofundamento das questões voltadas para a construção de melhores alternativas sustentáveis na garantia de práticas que levem ao pleno funcionamento da gestão de resíduos sólidos tanto na cidade do Rio de Janeiro como no Brasil. 


\section{6. Referências bibliográficas}

ASSOCIAÇÃO BRASILEIRA DE EMPRESAS DE LIMPEZA PÚBLICA E RESÍDUOS ESPECIAIS. Panorama dos Resíduos Sólidos no Brasil 2013. Disponível em: <http://www.abrelpe.org.br/Panorama/panorama2013.pdf>. Acesso em: 12 mar 2015.

BASTOS, V. P. Jardim Gramacho e o território do lixo. In: PONTÍFICIA UNIVERSIDADE CATÓLICA DO RIO DE JANEIRO. Educação ambiental: formação de valores ético-ambientais para o exercício da cidadania no município de Duque de Caxias - Rio de Janeiro. Rio de Janeiro: NIMA, 2009 . p. 119-135.

. O lixão de Gramacho e os catadores de materiais recicláveis: território extraordinário do lixo. Periferia: Educação, Cultura \& Sociedade, v. 4/5, ns. 1-2, p. 78-88, 2012-2013.

Profissão: catador um estudo do processo de construção da identidade. Rio de Janeiro: Letra Capital, 2014.

BAUDRILLARD, J. A sociedade de consumo. Lisboa: Edições 70, 2007.

BAUMAN, Z. Vida para consumo. Rio de Janeiro: Zahar, 2008.

BRASIL. Ministério das Cidades. SNIS: Sistema Nacional de Informações sobre Saneamento. 2013. Disponível em: <http: http://www.snis.gov.br/ >. Acesso em: 3 mar 2015.

. Ministério do Meio Ambiente. Cidades sustentáveis. 2015. Disponível em: <http://www.ministeriodomeioambiente.gov.br/cidadessustentaveis>. Acesso em: 02 mar 2015.

Presidência da República. Lei $\mathbf{n}^{0} \mathbf{1 2 . 3 0 5}$, de 2 de agosto de 2010. Institui a Política Nacional de Resíduos Sólidos. Disponível em: < http://www.planalto.gov.br/ccivil_03/_ato2007-2010/2010/lei/112305.htm>. Acesso em: 04 fev. 2015.

Presidência da República. Lei no 9.795, de 27 de abril 1999. Institui a Política Nacional de Educação Ambiental. Disponível em: < http://www.planalto.gov.br/ccivil_03/leis/19795.htm>. Acesso em: 14 fev. 2015.

Presidência da República. Plano Nacional sobre Mudança do Clima. 2007. Disponível em : <http://www.mma.gov.br/estruturas/smcq_climaticas/_arquivos/plano_nacional_ mudanca_clima.pdf $>$. Acesso em: 20 mar 2015.

BROWN, Lester R. Eco-economia: Construindo uma economia para a terra. Salvador: UMA, 2003. 
CAPUCHA, L. Desafios da pobreza. Oeiras (Portugal): Celta, 2005

CICLUS AMBIENTAL. Disponível em: <http://www.ciclusambiental.com.br/> Acesso em: 24 fev 2015.

CITIZENS BUDGET COMISSION Disponível em: <http://www.cbcny.org/> Acesso em: 24 mar 2015.

COMPROMISSO EMPRESARIAL PARA RECICLAGEM. Disponível em: <http://www.cempre.org.br/>. Acesso em: 24 fev. 2015.

COOPER, T. Inadequate life?: evidence of consumer attitudes to product obsolescence. Journal of Consumer Policy, n. 27, p. 421-449, 2004.

DIAS, B.; BOMFIM, A. A “teoria do fazer” em educação ambiental crítica: uma reflexão construída em contraposição à Educação Ambiental Conservadora. In: ENCONTRO NACIONAL DE PESQUISA EM EDUCAÇÃO EM CIÊNCIAS, 8., Campinas, SP, 2011. [Atas do...]. Campinas, SP: ABRAPEC, 2011.

ENVIRONMENTAL PROTECTION AGENCY. USEPA. Waste prevention recycling and composting options: lessons from 30 US communities. Disponível em: < http://www.epa.gov/waste/conserve/downloads/recy-com/index.htm>. Acesso em: 22 fev 2015.

EXAME. Prefeitura do Rio vai multar quem jogar lixo nas ruas. 2013. Disponível em: <http://exame.abril.com.br/brasil/noticias/prefeitura-do-rio-vaimultar-quem-jogar-lixo-nas-ruas?page=2>. Acesso em: 26 abr 2015.

FEDERAL MINISTRY FOR THE ENVIRONMENT, NATURE CONSERVATION AND NUCLEAR SAFETY. Waste Prevention Programme of the German Government with the Involvement of the Federal Länder. 2013. Disponível em: < http://www.bmub.bund.de/fileadmin/Daten_BMU/Pools/Broschueren/abfallverme idungsprogramm_en_bf.pdf >. Acesso em: 05 mar 2015.

GADOTTI, M. Educar para a sustentabilidade: uma contribuição à década da educação para o desenvolvimento sustentável. São Paulo: Instituto Paulo Freire, 2008.

GAMERMAN, Tammy; BRECHER, Charles; DARDIA, Michael. A better way to pay for solid waste management. New York: Citizens Budget Commission, 2015. Disponível em: < http://www.cbcny.org/sites/default/files/REPORT_SOLIDWASTE_02052015_0. pdf >. Acesso em: 13 abr 2015.

GLOBAL ALLIANCE FOR INCINERATOR ALTERNATIVES. On The Road to Zero Waste Success successes and Lessons from around the World. 2012. Disponível em: < http://www.noburn.org/downloads/On\%20the\%20Road\%20to\%20Zero\%20Waste.pdf >. Acesso em: 12 mar 2015. 
GUIMARÃES, M. A formação de educadores ambientais. Campinas, SP: Papirus, 2004.

INSTITUTO BRASILEIRO DE GEOGRAFIA E ESTATÍSTICA. 2013. Rio de Janeiro. Disponível em: <http://www.ibge.gov.br/home/>. Acesso em: 15 out 2014.

INTERGOVERNMENTAL PANEL ON CLIMATE CHANGE. Climate change 2013: the physical sciences basis: summary for plicymakers. 2013. Disponível em: <:https://www.ipcc.ch/pdf/assessmentreport/ar5/wg1/WGIAR5_SPM_brochure_en.pdf>. Acesso em: 19 mar 2015.

JACOBI, P. Educação ambiental, cidadania e sustentabilidade. Cadernos de Pesquisa, n. 118, p. 189-205, março/ 2003.

LEONARD, A. The story of stuff.: the impact of overconsumption on the planet, our communities, and our health - and how we can make it better. New York: Simon \& Schuster, 2010.

LOUREIRO, C. F. B. Trajetória e fundamentos da educação ambiental. São Paulo: Cortez, 2004.

MANZINI, E.; VEZZOLI, C. O desenvolvimento de produtos sustentáveis: os requisitos ambientais dos produtos industriais. São Paulo: EDUSP, 2002.

MELLO, G. Notas sobre o gerenciamento de resíduo sólido urbanos no Brasil. BNDES Setorial, Rio de Janeiro, n. 27, p. 101-120, mar. 2008.

MONTEIRO, José Henrique Penido et al. (org.). Manual de gerenciamento integrado de resíduos sólidos. Rio de Janeiro: IBAM, 2001.

OHYO. Ohyo the collapsabottle. Disponível em: < http://www.ohyo.me/ > Ohyo. Acesso em: 10 fev 2015.

PETROBRAS. Refinaria gera energia com biogás do Aterro de Gramacho. 2014. Disponível em: < http://www.petrobras.com.br/fatos-e-dados/refinaria-geraenergia-com-biogas-do-aterro-de-gramacho.htm> Petrobras. Acesso em: 10 mar 2015.

PIMENTEIRA, C. Gestão integrada de resíduos sólidos no Rio de Janeiro: Impactos das decisões dos gestores nas políticas públicas. 2010. $280 \mathrm{f}$. Tese (Doutorado) - Universidade Federal do Rio de Janeiro. Coordenação dos Programas de Pós-graduação de Engenharia. Rio de Janeiro, 2010.

PlaNYC: a greener, greater New York: update april 2011e. Disponível em: $<$ http://smedia.nyc.gov/agencies/planyc2030/pdf/planyc_2011_planyc_full_report.pdf>. Acesso em: 30 jan 2015. 
PRICE, Jane L. The landfill directive and challenge ahead: demands and pressures on the UK householder. Resources, Conservation \& Recycling, n. 32, p. 333348, 2001.

RAMOS, Mar Garcia. Gestión integral de los residuos sólidos urbanos. Resíduos: revista técnica, Bilbao, v. 8, n. 41, mar./abr. 1998.

RIBEIRO, L. Cidade e cidadania: inclusão urbana e justiça social. In: MOYSÈS, A. (org.) Cidade, segregação urbana e planejamento. Goiânia: UCG, 2005. p. 45-62.

RIO DE JANEIRO (Município). Companhia Municipal de Limpeza Urbana. Disponível em: <http://www.rio.rj.gov.br/web/comlurb> Acesso em: 2 fev. 2015.

RIO DE JANEIRO (Município). Inventário e Cenário de Emissões dos Gases de Efeito Estufa da Cidade do Rio de Janeiro: resumo técnico. Rio de Janeiro.

Coleção Estudos Cariocas, n. 20110301, Maio/2011. Disponível em: < http://portalgeo.rio.rj.gov.br/estudoscariocas/download\%5C3059_Invent\%C3\%A 1rio $\% 20 \mathrm{e} \% 20 \mathrm{Cen} \% \mathrm{C} 3 \%$ A1rio $\% 20 \mathrm{de} \% 20 \mathrm{Emiss} \% \mathrm{C} 3 \% \mathrm{~B} 5 \mathrm{es} \% 20 \mathrm{de} \% 20 \mathrm{Gases} \% 2$ 0do\%20Efeito\%20Estufa\%20da\%20Cidade\%20do\%20Rio\%20de\%20Janeiro_M AR_2011.pdf>. Acesso em: 25 mar 2015.

RIO DE JANEIRO (Município). Plano Municipal de Gestão Integrada de Resíduos Sólidos: PMGIRS da Cidade do Rio de Janeiro - agosto 2012 - agosto 2016. Disponível em: <http://www.rio.rj.gov.br/dlstatic/10112/3035089/DLFE47507.pdf/Plano_Gestao_Integrada_Residuos.pdf >. Acesso em: 25 jan 2015.

SARLO, Beatriz. Cenas da vida pós-moderna: intelectuais, arte e videocultura na Argentina.2.ed. Rio de Janeiro: UFRJ, 2000.

SLADE, G. Made to break: technology and obsolescence in America. London: Harvard University Press, 2006.

SYLVAN, D. Municipal solid waste in New York City: an economic and environmental analysis of disposal options. New York League of Conservation Voters Education Fund, 2012. Disponível em: < http://nylcvef.org/wpcontent/uploads/2013/07/Solid-Waste-Background-Paper.pdf >. Acesso em: $27 \mathrm{fev}$ 2015 .

TANSEY, R. Preventing waste: recycling isn't enough for a circular economy. Friends of the earth Europe, February 2015. Disponível em: < http://www.foeeurope.org/sites/default/files/resource_use/2015/preventing_waste. pdf.>. Acesso em: 12 abr 2015.

TINELLI, F. et al. Diagnóstico do sistema de coleta seletiva implantado no município do Rio de Janeiro. In: Congresso Brasileiro de Engenharia Sanitária e Ambiental, 23., 2005, Campo Grande/MS. [Anais...]. Campo Grande: ABES, 2005. 
UNITED STATES CENSUS BUREAU. Census.gov. Disponível em: <http://census.gov/ >. Acesso em: 15 fev 2015.

UNITED STATES ENVIRONMENTAL PROTECTION AGENCY. Disponível em: < http://www.epa.gov/>. Acesso em: 21 jan 2015.

WOOLLEY, M. Choreographing obsolescence: ecodesign: the pleasure/ dissatisfaction cycle. London: University of London, 2003. p. 77-81.

WORLD WIDE FUND FOR NATURE. Disponível em: <http://www.wwf.org.br/natureza_brasileira/especiais/pegada_ecologica/>. Acesso em: 10 maio 2015.

ZACAR, C. R. H.; ONO, M. M. Design, obsolescência e sustentabilidade. In: CONGRESSO BRASILEIRO DE PESQUISA E DESENVOLVIMENTO EM DESIGN, 9., 2010, São Paulo. Anais... São Paulo: Universidade Anhembi Morumbi, 2010. 